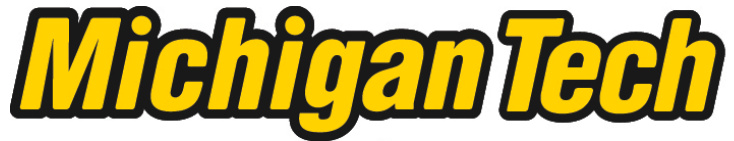 \\ Michigan Technological University Create the Future Digital Commons @ Michigan Tech
}

Dissertations, Master's Theses and Master's Reports - Open

Dissertations, Master's Theses and Master's

Reports

2013

\section{PROPERTIES AND STRUCTURES OF Li-N BASED HYDROGEN STORAGE MATERIALS}

Junqing Zhang

Michigan Technological University

Follow this and additional works at: https://digitalcommons.mtu.edu/etds

Part of the Materials Chemistry Commons, and the Physical Chemistry Commons Copyright 2013 Junqing Zhang

\section{Recommended Citation}

Zhang, Junqing, "PROPERTIES AND STRUCTURES OF Li-N BASED HYDROGEN STORAGE MATERIALS", Dissertation, Michigan Technological University, 2013.

https://doi.org/10.37099/mtu.dc.etds/579

Follow this and additional works at: https://digitalcommons.mtu.edu/etds

3 Part of the Materials Chemistry Commons, and the Physical Chemistry Commons 


\title{
PROPERTIES AND STRUCTURES OF Li-N BASED HYDROGEN STORAGE MATERIALS
}

\author{
By \\ Junqing Zhang \\ A DISSERTATION \\ Submitted in partial fulfillment of the requirements for the degree of \\ DOCTOR OF PHILOSOPHY \\ In Materials Science and Engineering \\ MICHIGAN TECHNOLOGICAL UNIVERSITY \\ 2013 \\ (C) 2013 Junqing Zhang
}



This dissertation has been approved in partial fulfillment of the requirements for the Degree of DOCTOR OF PHILOSOPHY in Materials Science and Engineering.

\section{Department of Materials Science and Engineering}

Dissertation Advisor: $\quad$ Yun Hang Hu

Committee Member: $\quad$ Jaroslaw W. Drelich

Committee Member: $\quad$ Stephen A. Hackney

Committee Member: $\quad$ Feng Zhao

Department Chair: $\quad$ Stephen L. Kampe 



\section{Table of Contents}

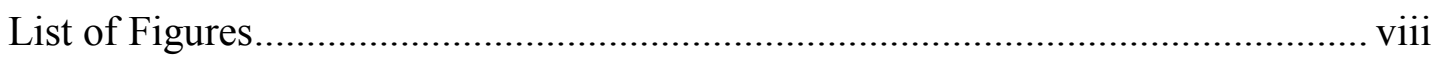

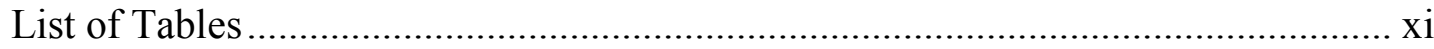

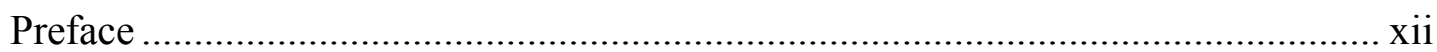

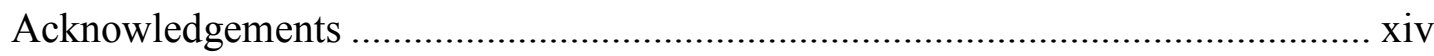

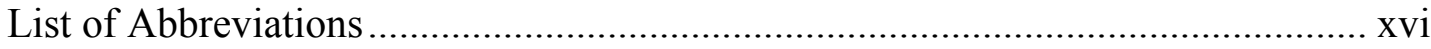

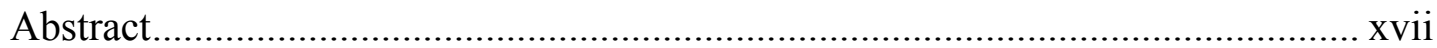

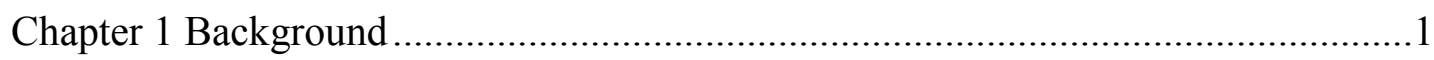

1.1 Why choosing hydrogen as fuel for transportation? .....................................

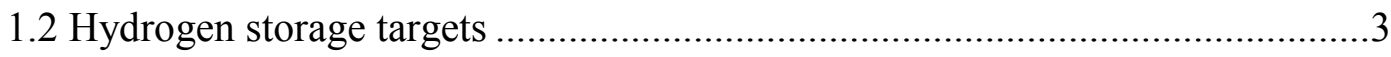

1.3 Technologies for hydrogen storage.....................................................4

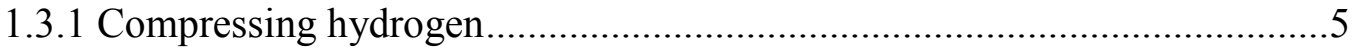

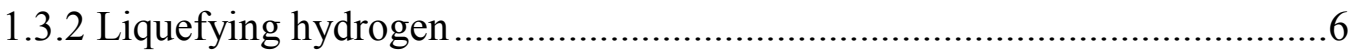

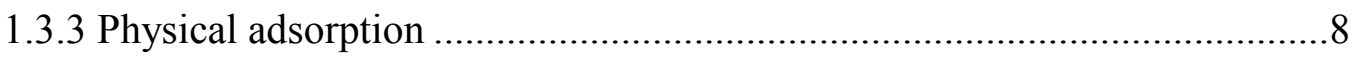

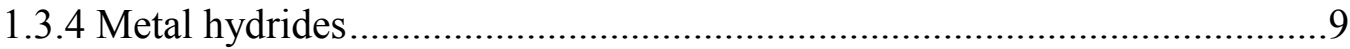

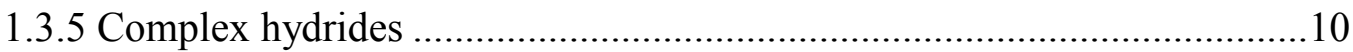

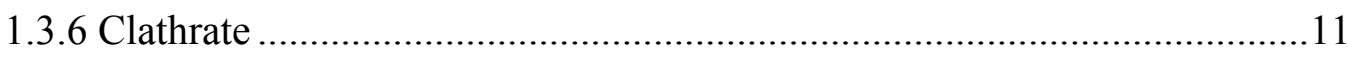

1.4 Lithium nitride for hydrogen storage.................................................. 11

1.5 Lithium nitride crystal structure and optical property ................................. 15

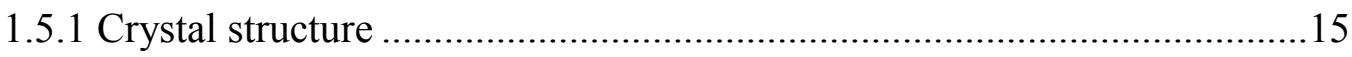

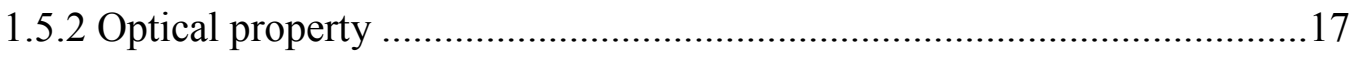

1.6 Lithium nitride halides structure and properties ..................................... 18

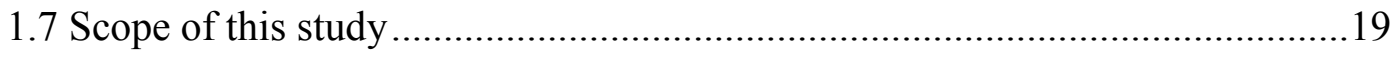

Chapter 2 Decomposition of lithium amide * ......................................................21

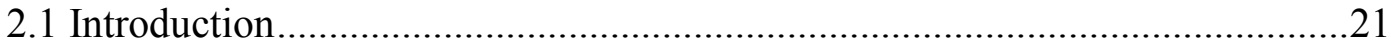

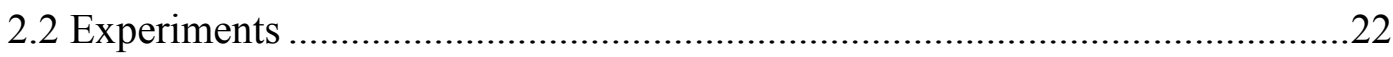

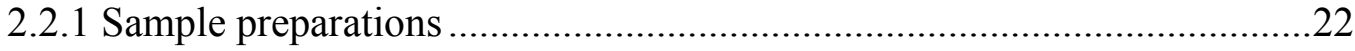

2.2.2 Temperature-programmed decomposition ..........................................23

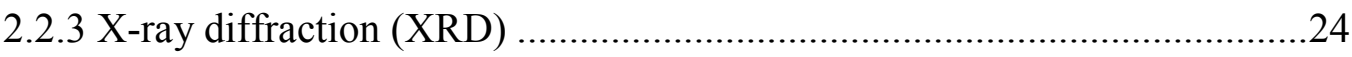




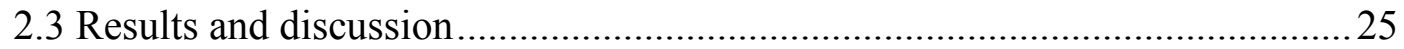

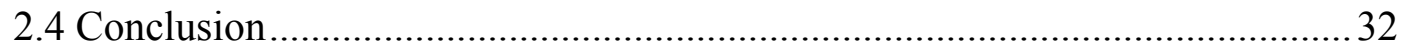

Chapter 3 Decomposition of lithium imide *........................................................... 33

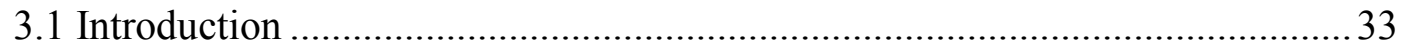

3.2 Experiments and kinetic calculation method....................................................34

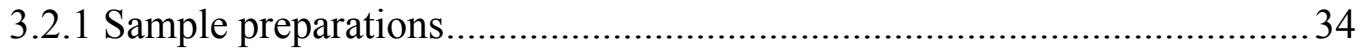

3.2.2 Temperature-programmed decomposition..................................................34

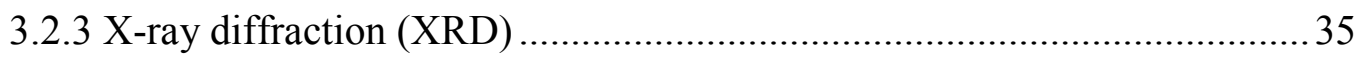

3.2.4 Kinetic calculation method for TPD-TCD peaks ........................................35

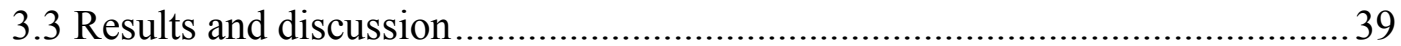

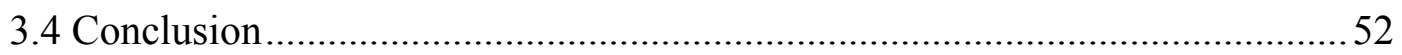

Chapter 4 Effect of anion promoter $\mathrm{Cl}^{-}$on the decomposition of lithium amide *....53

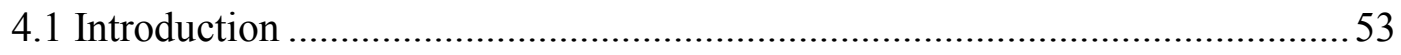

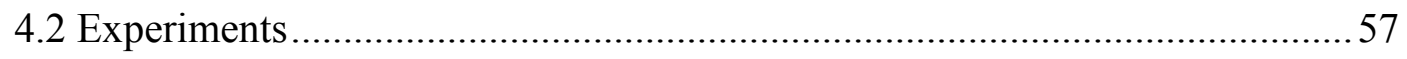

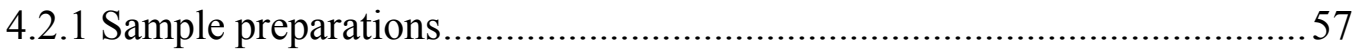

4.2.2 Temperature-programmed decomposition................................................5 57

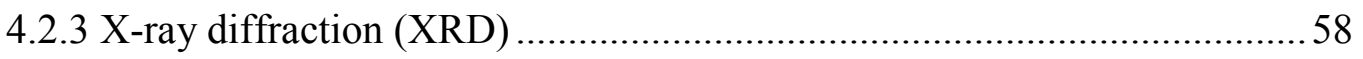

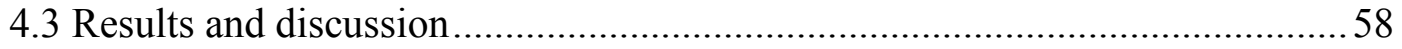

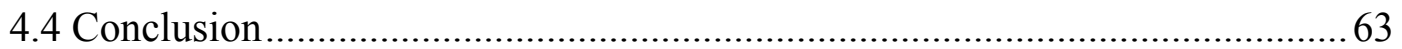

Chapter 5 Chemical stability of lithium nitride in air* ............................................6 64

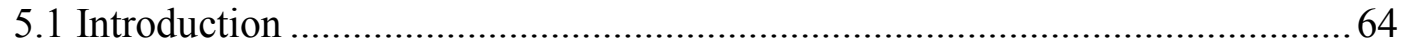

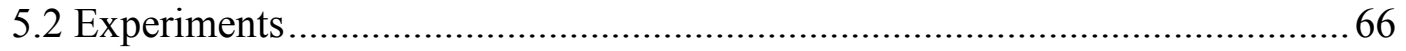

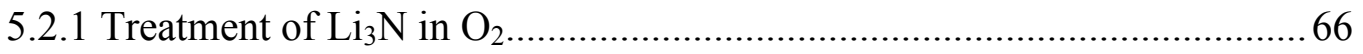

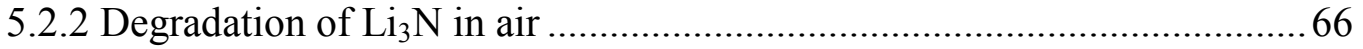

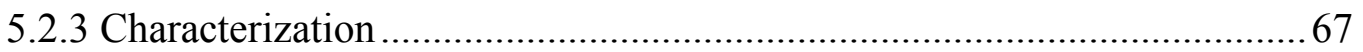

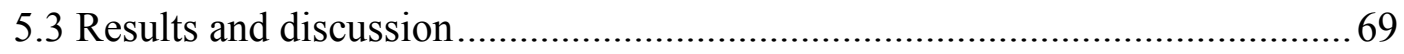

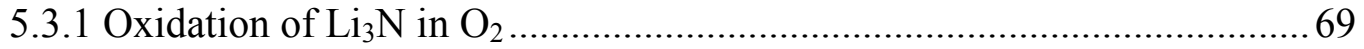

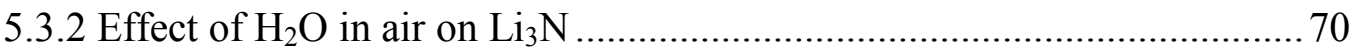

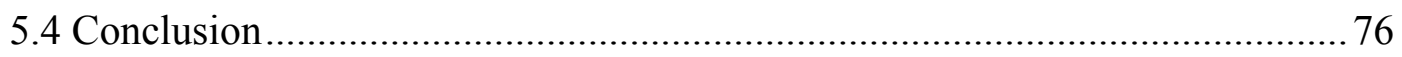

Chapter 6 Chemical stability of lithium nitride bromide $\mathrm{Li}_{13} \mathrm{~N}_{4} \mathrm{Br}$ in air ${ }^{*} \ldots \ldots \ldots \ldots \ldots . .78$ 


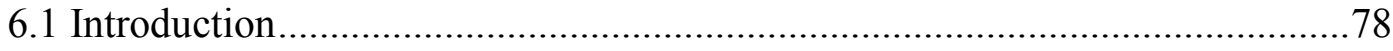

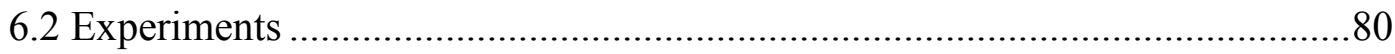

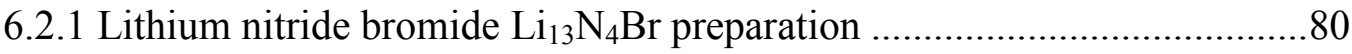

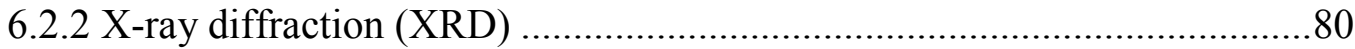

6.2.3 Temperature-programmed decomposition mass spectroscopy (TPD-MS) 81

6.2.4 Ultraviolet-visible (UV-vis) absorption ..................................................... 82

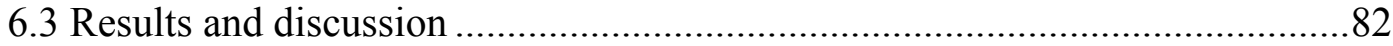

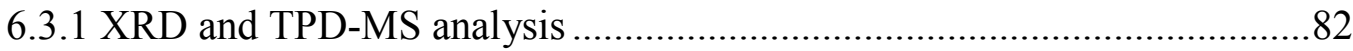

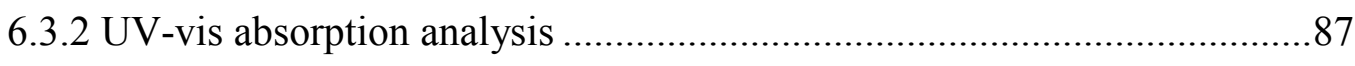

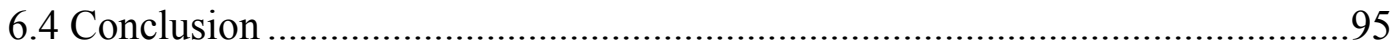

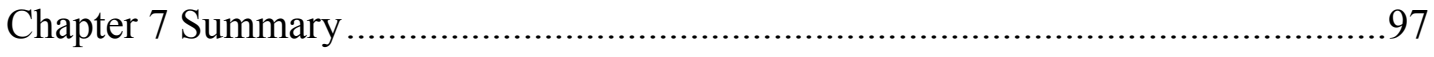

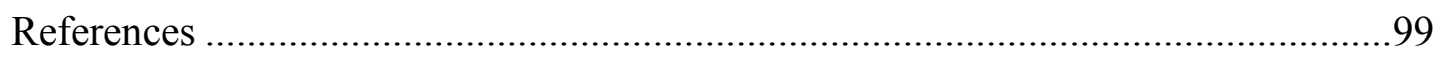

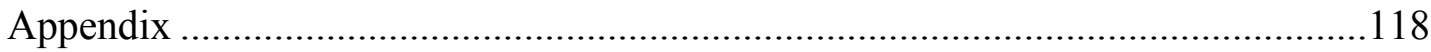




\section{List of Figures}

Figure 1.1 Petroleum consumption estimates by sector from 1949 to 2011 in USA [1].

Figure 1.2 Volumetric density of compressed hydrogen gas as a function of gas pressure comparing with the ideal gas and liquid hydrogen [7]

Figure 1.3 Primitive phase diagram for hydrogen. Liquid hydrogen only exists within

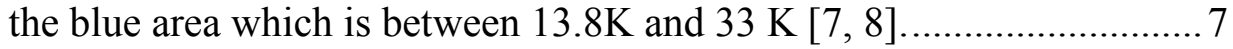

Figure 1.4 Logarithm of dissociation pressure vs. reciprocal of absolute temperature [53].

Figure 1.5 Equilibrium hydrogen pressure and reaction temperature of Reaction (1.2).

Figure 2.1 Thermal conductivity detector of Varian 3300 Gas Chromatograph. ......23

Figure 2.2 HP 5970 series mass selective detector. ............................................. 24

Figure 2.3 Scintag XDS2000 Powder Diffractometer. ..........................................25

Figure 2.4 (a)TPD-TCD profile and (b) TPD-MS profile of pure $\mathrm{LiNH}_{2}$................ 27

Figure 2.5 (a) TPD-TCD profile and (b) TPD-MS profile of $\mathrm{LiNH}_{2}$ with a cooler where produced gases were cooled to $159 \mathrm{~K}$ before entering TCD and

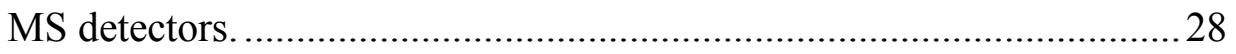

Figure 2.6 XRD patterns of the solid products from the TPD process of $\mathrm{LiNH}_{2}$ that was stopped at (a) room temperature, (b) $160{ }^{\circ} \mathrm{C}$, (c) $330{ }^{\circ} \mathrm{C}$, (d)

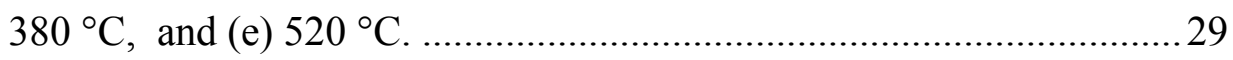

Figure 3.1 Typical TPD-TCD profile of a sample with a uniform gas product.........36

Figure 3.2 TPD-TCD profile of $\mathrm{Li}_{2} \mathrm{NH}$. The two peaks are resolved by (A) Gaussian equation fitting and (B) kinetic calculation.

Figure 3.3 lnhi vs. (1/Ti-SplnSi/hpTp2) for the first peak of the composition of $\mathrm{Li}_{2} \mathrm{NH}$. 44 
Figure $3.4 \operatorname{lnhi}$ vs. (1/Ti-SplnSi/hpTp2) for the second peak of the composition of $\mathrm{Li}_{2} \mathrm{NH}$. 46

Figure 3.5 XRD patterns of the solid products from the TPD process of $\mathrm{Li}_{2} \mathrm{NH}$ that were stopped at (a) $550{ }^{\circ} \mathrm{C}$, (b) $607{ }^{\circ} \mathrm{C}$, (c) $650{ }^{\circ} \mathrm{C}$, (d) $680{ }^{\circ} \mathrm{C}$, (e) $690{ }^{\circ} \mathrm{C}$, (f) $700{ }^{\circ} \mathrm{C}$, and (g) $710{ }^{\circ} \mathrm{C}$.

Figure 3.6 Lattice parameters of the solid products from the TPD process of $\mathrm{Li}_{2} \mathrm{NH}$ vs. the molar fraction of $\mathrm{Li}_{2} \mathrm{NH}$ in $\mathrm{Li}_{2} \mathrm{NH} / \mathrm{Li}_{4} \mathrm{NH}$ solid solution. .50

Figure 3.7 (a) TPD-TCD profile and (b) TPD-MS profile of $\mathrm{Li}_{3} \mathrm{~N}$. .51

Figure 4.1 Thermal desorption profiles of $\mathrm{H}_{2}$ and $\mathrm{NH}_{3}$ of the ball milled mixtures of $\mathrm{LiNH}_{2}$ and $\mathrm{LiH}$ with 1:1 molar ratio, in which added with a small amount $(1 \mathrm{~mol} \%)$ of $\mathrm{Ni}, \mathrm{Fe}$ and $\mathrm{Co}$ nanometer sized metals, and $\mathrm{VCl}_{3}$ and $\mathrm{TiCl}_{3}$ before milling [40]. .55

Figure 4.2 (A) TPD-TCD profiles and (B) TPD-MS profiles of LiCl-doped $\mathrm{LiNH}_{2}$ with various $\mathrm{LiNH}_{2} / \mathrm{LiCl}$ mole ratios: (a) pure $\mathrm{LiNH}_{2}$, (b) 9:1, (c) 8:2, (d) 7:3, (e) 6:4, (f) 5:5, (g) 4:6, (h) 3:7, (i) 2:8, and (j) 1:9.

Figure 4.3 XRD patterns of the solid products from the TPD process of $\mathrm{LiNH}_{2} / \mathrm{LiCl}$ (8:2 molar ratio) that was stopped at various temperatures: (a) room temperature, (b) $160{ }^{\circ} \mathrm{C}$, (c) $275^{\circ} \mathrm{C}$, (d) $320^{\circ} \mathrm{C}$, (e) $330{ }^{\circ} \mathrm{C}$, (f) $380{ }^{\circ} \mathrm{C}$, (g) $520{ }^{\circ} \mathrm{C}$, and (h) $570{ }^{\circ} \mathrm{C}$. 62

Figure 5.1 Shimadzu UV-2450 Spectrometer. ..........................................................68

Figure 5.2 Perkin Elmer Spectrum One FTIR spectrometer. .68

Figure 5.3 XRD patterns of $\mathrm{Li}_{3} \mathrm{~N}$ (a) without treatment and treated with $\mathrm{O}_{2}$ for $3 \mathrm{~h}$ at (b) $170{ }^{\circ} \mathrm{C}$, (c) $230{ }^{\circ} \mathrm{C}$, (d) $280^{\circ} \mathrm{C}$, and (e) $330{ }^{\circ} \mathrm{C}$. .70

Figure 5.4 XRD patterns of $\mathrm{Li}_{3} \mathrm{~N}$ exposed to air for (a) $0 \mathrm{~min}$, (b) $15 \mathrm{~min}$, (c) $30 \mathrm{~min}$, (d) $1 \mathrm{~h}$, (e) $2 \mathrm{~h}$, (f) $4 \mathrm{~h}$, (g) $14 \mathrm{~h}$ (h) $32 \mathrm{~h}$, and (i) $100 \mathrm{~h}$ .72

Figure 5.5 FTIR spectra of $\mathrm{Li}_{3} \mathrm{~N}$ exposed to air for (a) $0 \mathrm{~min}$, (b) $15 \mathrm{~min}$, (c) $30 \mathrm{~min}$, (d) $1 \mathrm{~h}$, (e) $2 \mathrm{~h}$, (f) $4 \mathrm{~h}$, (g) $14 \mathrm{~h}$ (h) $32 \mathrm{~h}$, and (i) $100 \mathrm{~h}$ .74

Figure 5.6 UV-vis absorption spectra of $\mathrm{Li}_{3} \mathrm{~N}$ exposed to (A) air with relative humidity of $16 \%$ and (B) air with relative humidity of $88 \% \ldots \ldots \ldots \ldots \ldots . . . .75$

Figure 5.7 UV-vis absorption spectra of individual $\mathrm{Li}_{2} \mathrm{O}, \mathrm{LiOH}$, and $\mathrm{Li}_{2} \mathrm{CO}_{3}$.........76 
Figure 6.1 XRD patterns of $\mathrm{Li}_{13} \mathrm{~N}_{4} \mathrm{Br}$ in air for various time before testing. (a) Newly made $\mathrm{Li}_{13} \mathrm{~N}_{4} \mathrm{Br}$, (b) $1 \mathrm{~h}$, (c) $2 \mathrm{~h}$, (d) $4 \mathrm{~h}$, (e) $14 \mathrm{~h}$, (f) $32 \mathrm{~h}$ and (g) $100 \mathrm{~h} . . . .84$

Figure 6.2 TPD-MS profile of $\mathrm{Li}_{13} \mathrm{~N}_{4} \mathrm{Br}$ in air for (a) $0 \mathrm{~h}$, (b) $1 \mathrm{~h}$, (d) $6 \mathrm{~h}$, (d) $30 \mathrm{~h}$, (e) $46 \mathrm{~h}$, and (f) $150 \mathrm{~h}$. 86

Figure 6.3 UV-vis absorption spectra of (A) $\mathrm{Li}_{13} \mathrm{~N}_{4} \mathrm{Br}$ and (B) $\alpha-\mathrm{Li}_{3} \mathrm{~N}$ in air for various time.

Figure 6.4 The energy gap calculation of sample $\mathrm{Li}_{13} \mathrm{~N}_{4} \mathrm{Br}$ in air for various time. (a) Newly made $\mathrm{Li}_{13} \mathrm{~N}_{4} \mathrm{Br}$, (b) $0.5 \mathrm{~h}$, (c) $1 \mathrm{~h}$, (d) $1.5 \mathrm{~h}$, (e) $2 \mathrm{~h}$, (f) $2.5 \mathrm{~h}$, (g) $3 \mathrm{~h}$, (h) 3.5h, (i) 4h, (j) 4.5h, (k) 7.3h, (1) 9h, (m) 16.2h, (n) 27.7h, (o) 40.3h, (p) $99.3 \mathrm{~h}$. 89

Figure 6.5 UV-vis absorption (at wavelength $428 \mathrm{~nm}, 528 \mathrm{~nm}, 628 \mathrm{~nm}$, and $728 \mathrm{~nm}$ ) of $\mathrm{Li}_{13} \mathrm{~N}_{4} \mathrm{Br}$ in air with time. 91

Figure 6.6 Reaction order fitting of the degradation of $\mathrm{Li}_{13} \mathrm{~N}_{4} \mathrm{Br}$ in air: $\mathrm{N}-\mathrm{t}$ and $\ln (\mathrm{N})$ $-\mathrm{t}$. 94

Figure 6.7 Reaction order fitting of the degradation of $\mathrm{Li}_{13} \mathrm{~N}_{4} \mathrm{Br}$ in air: $1 / \mathrm{N}-\mathrm{t}$, $1 / \mathrm{N}^{1.43}-\mathrm{t}$, and $1 / \mathrm{N}^{2}-\mathrm{t}$. 95 


\section{List of Tables}

Table 1.1 Mass energy densities for various fuels [4] ............................................

Table 1.2 The DOE targets for onboard hydrogen storage systems for light-duty

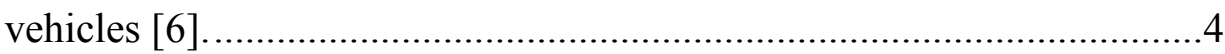

Table 3.1 Molar fraction of $\mathrm{H}_{2}$ and $\mathrm{N}_{2}$ produced in the decomposition of $\mathrm{Li}_{2} \mathrm{NH}$ at

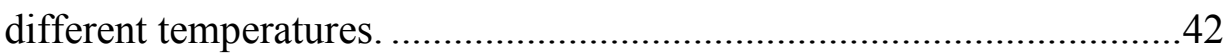

Table 3.2 Data obtained from the first peak of the composition of $\mathrm{Li}_{2} \mathrm{NH}$................44

Table 3.3 Data obtained from the second peak of the composition of $\mathrm{Li}_{2} \mathrm{NH}$...........46

Table 3.4 Lattice parameters of the solid products from the TPD process of $\mathrm{Li}_{2} \mathrm{NH} .50$

Table 5.1 Molar ratio of $\beta-\mathrm{Li}_{3} \mathrm{~N}$ to $\alpha-\mathrm{Li}_{3} \mathrm{~N}$ in the $\mathrm{Li}_{3} \mathrm{~N}$ sample exposed to air..........73

Table 6.1 Reaction order fitting of the degradation of $\mathrm{Li}_{13} \mathrm{~N}_{4} \mathrm{Br}$ in air. ....................93 


\section{Preface}

Hydrogen is considered an environmentally cleaner source of energy in transportation applications. Hydrogen storage is the key issue to achieve this purpose. Lithium nitride $\left(\mathrm{Li}_{3} \mathrm{~N}\right)$ is an important material which can be used for hydrogen storage. The decompositions of lithium amide $\left(\mathrm{LiNH}_{2}\right)$ and lithium imide $\left(\mathrm{Li}_{2} \mathrm{NH}\right)$ are important steps for hydrogen storage in $\mathrm{Li}_{3} \mathrm{~N}$. The formation of intermediate species during the decomposition of $\mathrm{LiNH}_{2}$ and $\mathrm{Li}_{2} \mathrm{NH}$ has never been studied. The anion promoter effect on the decomposition of $\mathrm{LiNH}_{2}$ has never been studied either.

In this dissertation, the research work was focused on (1) the mechanism of the decomposition of $\mathrm{LiNH}_{2}$; (2) the mechanism of the decomposition of $\mathrm{Li}_{2} \mathrm{NH}$; (3) the effect of anion promoter on the decomposition of $\mathrm{LiNH}_{2}$; (4) the chemical stability of $\mathrm{Li}_{3} \mathrm{~N}$ in air; and (5) the chemical stability of $\mathrm{Li}_{13} \mathrm{~N}_{4} \mathrm{Br}$ in air.

My PhD work was supervised by Professor Yun Hang Hu. The work in the dissertation has been published in several peer-reviewed journals. Professor Hu and I are the only two authors in all the published papers. I performed the experiments and data analysis under the guidance of Professor Hu for the work in this dissertation. The material contained in Chapter 2 and 4 was previously published in the journal Industrial and Engineering Chemistry Research. The material contained in Chapter 3 was previously published in the journal International Journal of Hydrogen Energy. The material contained in Chapter 5 and 6 was planned for submission to the journal Industrial and Engineering Chemistry Research. This work would not be possible without the guidance, encouragement, and support from Professor Hu. This 
dissertation would not be accomplished without the guidance, encouragement, and support from Professor Hu. 


\section{Acknowledgements}

Firstly, I appreciate my advisor, Professor Yun Hang Hu, very much. He provided me financial support. He guided me how to do research, instructed me to publish journal papers, and inspired me scientific thinking. His impact on me will benefit me for the rest of my life.

Next, I would like to thank all faculty and staff in Materials Science and Engineering Department at Michigan Tech for their help and support. Especially, I would like to thank my committee members: Professor Jaroslaw W. Drelich, Professor Stephen A. Hackney, and Professor Feng Zhao for reading my dissertation, listening to my presentation, and giving constructive suggestions. Also, I would like to express my appreciation to Professor Stephen L. Kampe, Professor Mark Plichta, Professor Douglas Swenson, Professor Peter D. Moran, and Professor Jiann-Yang (Jim) Hwang, for their guidance and encouragement.

Thanks are given to Stephen F. Forsell, Paul Fraley, Owen P. Mills, Edward A. Latitila, Patrick Quimby, Margaret Rothenberger, Beth Ruohonen, and Ruth Kramer for their assistance in chemicals ordering, experiments build up, and equipments operations.

I also would like to thank my research group members, Lei Zhang, Yan Huo, Sanchai Kuboon, Pubodee Ratana-Arsanarom, Hui Wang, Peifu Cheng, Bing Han, and Wei Wei, for their assistance and help on my research works. Also, I would like to thank Andrew Galerneau on the Fourier transform infrared spectroscopy measurement. 
Finally, I would like to thank my family and friends for all their supports and encouragements. Without them, I would never have accomplished what I have. 


\section{List of Abbreviations}

\begin{tabular}{cc}
\hline Abbreviation & Full name \\
\hline FTIR & Fourier transform infrared spectroscopy \\
GC & gas chromatography \\
MS & mass spectrometry \\
TCD & thermal conductivity detector \\
TPD & temperature programmed decomposition \\
XRD & X-ray diffraction \\
\hline
\end{tabular}




\begin{abstract}
Traditional transportation fuel, petroleum, is limited and nonrenewable, and it also causes pollutions. Hydrogen is considered one of the best alternative fuels for transportation. The key issue for using hydrogen as fuel for transportation is hydrogen storage. Lithium nitride $\left(\mathrm{Li}_{3} \mathrm{~N}\right)$ is an important material which can be used for hydrogen storage. The decompositions of lithium amide $\left(\mathrm{LiNH}_{2}\right)$ and lithium imide $\left(\mathrm{Li}_{2} \mathrm{NH}\right)$ are important steps for hydrogen storage in $\mathrm{Li}_{3} \mathrm{~N}$. The effect of anions (e.g. $\mathrm{Cl}^{-}$) on the decomposition of $\mathrm{LiNH}_{2}$ has never been studied. $\mathrm{Li}_{3} \mathrm{~N}$ can react with $\mathrm{LiBr}$ to form lithium nitride bromide $\mathrm{Li}_{13} \mathrm{~N}_{4} \mathrm{Br}$ which has been proposed as solid electrolyte for batteries.

The decompositions of $\mathrm{LiNH}_{2}$ and $\mathrm{Li}_{2} \mathrm{NH}$ with and without promoter were investigated by using temperature programmed decomposition (TPD) and X-ray diffraction (XRD) techniques. It was found that the decomposition of $\mathrm{LiNH}_{2}$ produced $\mathrm{Li}_{2} \mathrm{NH}$ and $\mathrm{NH}_{3}$ via two steps: $\mathrm{LiNH}_{2}$ into a stable intermediate species $\left(\mathrm{Li}_{1.5} \mathrm{NH}_{1.5}\right)$ and then into $\mathrm{Li}_{2} \mathrm{NH}$. The decomposition of $\mathrm{Li}_{2} \mathrm{NH}$ produced $\mathrm{Li}, \mathrm{N}_{2}$ and $\mathrm{H}_{2}$ via two steps: $\mathrm{Li}_{2} \mathrm{NH}$ into an intermediate species $-\mathrm{Li}_{4} \mathrm{NH}$ and then into $\mathrm{Li}$. The kinetic analysis of $\mathrm{Li}_{2} \mathrm{NH}$ decomposition showed that the activation energies are $533.6 \mathrm{~kJ} / \mathrm{mol}$ for the first step and $754.2 \mathrm{~kJ} / \mathrm{mol}$ for the second step. Furthermore, XRD demonstrated that the $\mathrm{Li}_{4} \mathrm{NH}$, which was generated in the decomposition of $\mathrm{Li}_{2} \mathrm{NH}$, formed a solid solution with $\mathrm{Li}_{2} \mathrm{NH}$. In the solid solution, $\mathrm{Li}_{4} \mathrm{NH}$ possesses a similar cubic structure as $\mathrm{Li}_{2} \mathrm{NH}$. The lattice parameter of the cubic $\mathrm{Li}_{4} \mathrm{NH}$ is $0.5033 \mathrm{~nm}$.
\end{abstract}


The decompositions of $\mathrm{LiNH}_{2}$ and $\mathrm{Li}_{2} \mathrm{NH}$ can be promoted by chloride ion $\left(\mathrm{Cl}^{-}\right)$. The introduction of $\mathrm{Cl}^{-}$into $\mathrm{LiNH}_{2}$ resulted in the generation of a new $\mathrm{NH}_{3}$ peak at low temperature of $250{ }^{\circ} \mathrm{C}$ besides the original $\mathrm{NH}_{3}$ peak at $330{ }^{\circ} \mathrm{C}$ in TPD profiles. Furthermore, $\mathrm{Cl}^{-}$can decrease the decomposition temperature of $\mathrm{Li}_{2} \mathrm{NH}$ by about $110^{\circ} \mathrm{C}$.

The degradation of $\mathrm{Li}_{3} \mathrm{~N}$ was systematically investigated with techniques of XRD, Fourier transform infrared (FT-IR) spectroscopy, and UV-visible spectroscopy. It was found that $\mathrm{O}_{2}$ could not affect $\mathrm{Li}_{3} \mathrm{~N}$ at room temperature. However, $\mathrm{H}_{2} \mathrm{O}$ in air can cause the degradation of $\mathrm{Li}_{3} \mathrm{~N}$ due to the reaction between $\mathrm{H}_{2} \mathrm{O}$ and $\mathrm{Li}_{3} \mathrm{~N}$ to $\mathrm{LiOH}$. The produced $\mathrm{LiOH}$ can further react with $\mathrm{CO}_{2}$ in air to $\mathrm{Li}_{2} \mathrm{CO}_{3}$ at room temperature. Furthermore, it was revealed that $\alpha-\mathrm{Li}_{3} \mathrm{~N}$ is more stable in air than $\beta$ $\mathrm{Li}_{3} \mathrm{~N}$.

The chemical stability of $\mathrm{Li}_{13} \mathrm{~N}_{4} \mathrm{Br}$ in air has been investigated by XRD, TPD-MS, and UV-vis absorption as a function of time. The aging process finally leads to the degradation of the $\mathrm{Li}_{13} \mathrm{~N}_{4} \mathrm{Br}$ into $\mathrm{Li}_{2} \mathrm{CO}_{3}$, lithium bromite $\left(\mathrm{LiBrO}_{2}\right)$ and the release of gaseous $\mathrm{NH}_{3}$. The reaction order $\mathrm{n}=2.43$ is the best fitting for the $\mathrm{Li}_{13} \mathrm{~N}_{4} \mathrm{Br}$ degradation in air reaction. $\mathrm{Li}_{13} \mathrm{~N}_{4} \mathrm{Br}$ energy gap was calculated to be 2.61 $\mathrm{eV}$. 


\section{Chapter 1 Background}

\subsection{Why choosing hydrogen as fuel for transportation?}

Transportation consumes around $2 / 3$ of petroleum in USA during the last few decades (Figure 1.1) [1]. Petroleum on earth, which is limited and nonrenewable, will be used up in the future. From the environment protection point of view, transportation by using petroleum based fuel (gasoline or diesel) can produce greenhouse gases, such as carbon dioxide $\left(\mathrm{CO}_{2}\right)$, which can cause global warming. Furthermore, Carbon monoxide $(\mathrm{CO})$, nitrogen oxides $\left(\mathrm{NO}_{\mathrm{x}}\right)$ and sulfur oxide $\left(\mathrm{SO}_{\mathrm{x}}\right)$ from the exhaust gas of petroleum based fuel vehicles have been shown to have variety of negative effects on public health and the natural environment. So, it is necessary and urgent to find an alternative fuel.

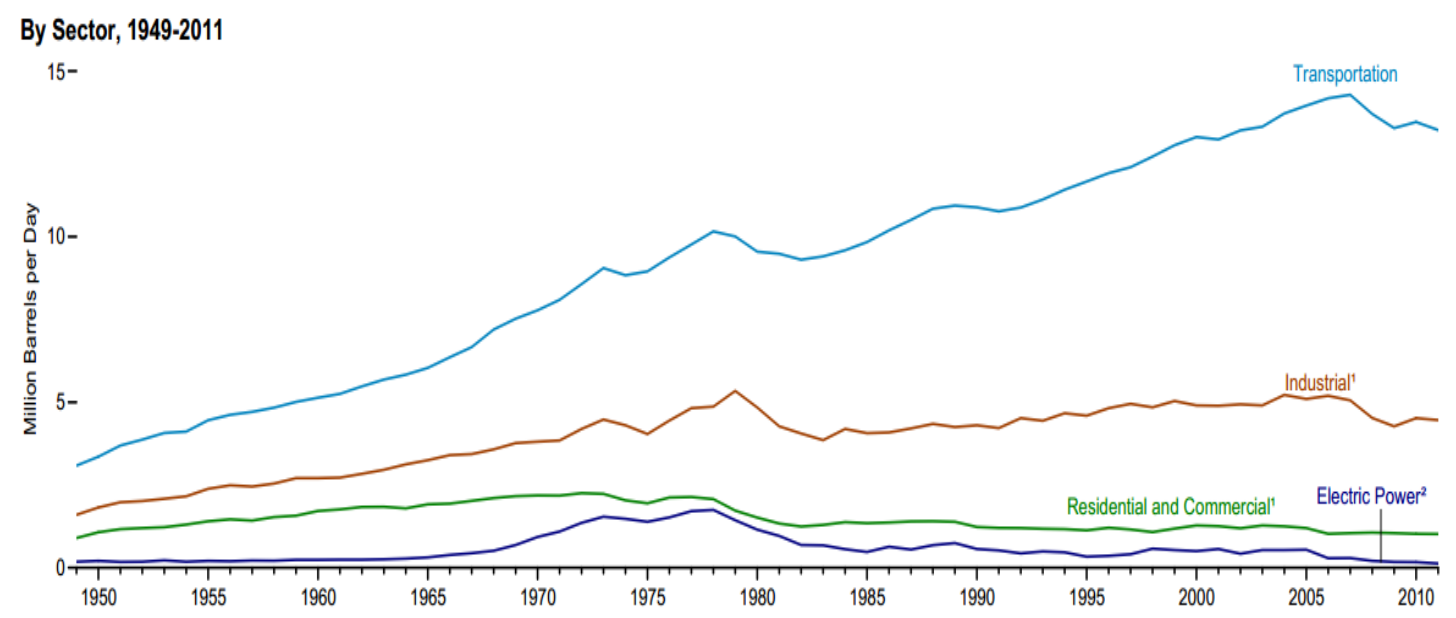

Figure 1.1 Petroleum consumption estimates by sector from 1949 to 2011 in USA [1]. (Reprinted from U.S. Energy Information Administration) 
Hydrogen, the most abundant element in the universe, is considered one of the best alternative fuels for transportation [2, 3]. Firstly, the mass energy density of hydrogen is much higher than other common fuels (Table 1.1) [4]. Secondly, by using hydrogen as fuel for transportation, it can reduce the dependence on petroleum. Thirdly, $\mathrm{H}_{2} \mathrm{O}$ is only a product which is clean and no pollution to the environment. Lastly, the hydrogen fuel cell efficiency (more than 60\%) is significantly higher than those powered by internal combustion engines (the internal combustion engine energy efficiency is only around 20\%) [5].

Table 1.1 Mass energy densities for various fuels [4]. (Reprinted from DOE)

\begin{tabular}{|c|c|c|c|}
\hline Fuel & $\begin{array}{l}\text { Hydrogen } \\
\text { weight } \\
\text { fraction }\end{array}$ & Ambient state & $\begin{array}{c}\text { Mass energy } \\
\text { density } \\
\text { (MJ/kg) }\end{array}$ \\
\hline Hydrogen & 1 & Gas & 120 \\
\hline Methane & 0.25 & Gas & $50(43)^{2}$ \\
\hline Ethane & 0.2 & Gas & 47.5 \\
\hline Propane & 0.18 & Gas (liquid) ${ }^{1}$ & 46.4 \\
\hline Gasoline & 0.16 & Liquid & 44.4 \\
\hline Ethanol & 0.13 & Liquid & 26.8 \\
\hline Methanol & 0.12 & Liquid & 19.9 \\
\hline
\end{tabular}

(1) A gas at room temperature, but normally stored as a liquid at moderate pressure. (2)The larger values are for pure methane. The values in parantheses are for a "typical" Natural Gas. 


\subsection{Hydrogen storage targets}

The key issue for using hydrogen as fuel for transportation is hydrogen storage. Hydrogen has the highest gravimetric energy densities of any known fuels (Table 1.1) [4]. However, its volumetric energy density is only a quarter of that of gasoline $(8 \mathrm{MJ} / \mathrm{L}$ for liquid hydrogen versus $32 \mathrm{MJ} / \mathrm{L}$ for gasoline). At 1 atm and room temperature, $2 \mathrm{~g}$ hydrogen gas has a volume of around 22.4 liters. So, it's a challenge to store hydrogen gas with such a low volumetric energy density, especially for the given requirements to achieve a driving range of greater than 300 miles $(500 \mathrm{~km})$ which is comparable with today's gasoline driven automobiles [6].

The DOE has performed a partnership with the U.S. DRIVE, the U.S. Council for Automotive Research, and major energy and utility companies to develop targets for onboard hydrogen storage systems for light-duty vehicles. The goal of the targets is to meet packaging, cost, safety, and performance requirements to be competitive with comparable vehicles in the market place [6]. The DOE targets for onboard hydrogen storage systems for light-duty vehicles are listed in table 1.2. 
Table 1.2 The DOE targets for onboard hydrogen storage systems for light-duty vehicles [6]. (Reprinted from DOE)

\begin{tabular}{lccc}
\hline storage parameter & Units & 2015 & Ultimate \\
\hline system gravimetric capacity & wt. \% & 5.5 & 7.5 \\
system volumetric capacity & $\mathrm{g} / \mathrm{L}$ & 40 & 70 \\
$\mathrm{H}_{2}$ delivery temperature (min./max.) & ${ }^{\circ} \mathrm{C}$ & $-40 / 85$ & $-40 / 95-105$ \\
operating pressure (min./max.) fuel cell & bar & $5 / 12$ & $3 / 12$ \\
\hline
\end{tabular}

\subsection{Technologies for hydrogen storage}

An effective hydrogen storage technology, which provides high storage capacity, suitable operating temperature, and fast kinetics, is a critical factor in the development of hydrogen fuel for transportation [2,6]. So far, three types of technologies are available to store hydrogen: compressing hydrogen, liquefying hydrogen, and hydrogen storage in solid materials. In general, hydrogen storage in solid materials is achieved via two processes: physical adsorption, in which hydrogen is adsorbed on the surface of solid materials, and chemical reactions, in which hydrogen reacts with solid materials to form new compounds. 


\subsubsection{Compressing hydrogen}

Compressing hydrogen is the easiest and commonest way for hydrogen storage. According to the ideal gas law, at constant temperature, increasing the gas pressure will reduce the gas volume, and improve the gas volumetric density. As shown in Figure 1.2, there is a deviation of the $\mathrm{H}_{2}$ gas from the ideal gas, especially at high pressure. With increasing pressure, the volumetric density of the hydrogen gas increases and reaches the maximum at about $55 \mathrm{~kg} / \mathrm{m}^{3}$. Further increasing of the hydrogen gas pressure has little impact on the volumetric density of the compressed hydrogen gas.

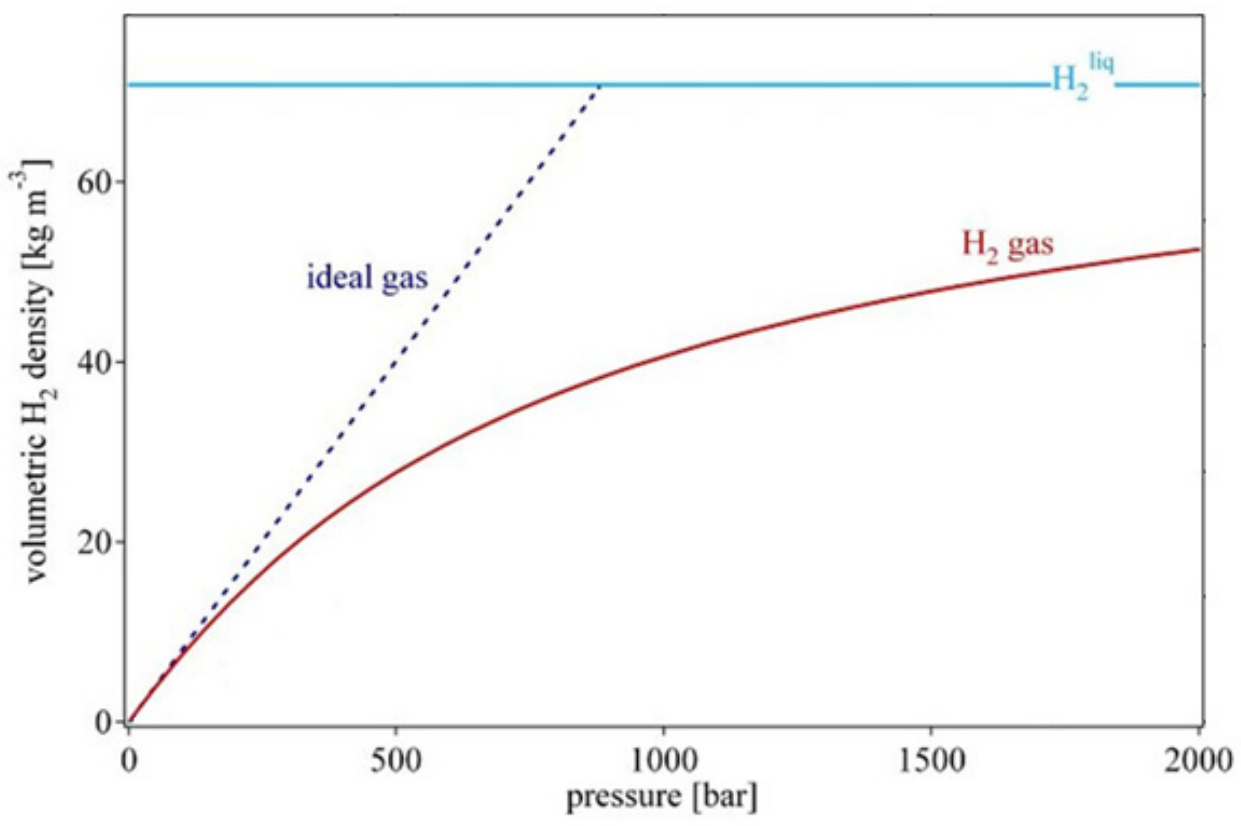

Figure 1.2 Volumetric density of compressed hydrogen gas as a function of gas pressure comparing with the ideal gas and liquid hydrogen [7]. (With permission from Springer) 
For the reality use of storing enough hydrogen fuel for a reasonable driving range of 400-500 km, compressing hydrogen requires a very high pressure (up to 700 bar), and this causes a safety issue related to tank rupture in an accident [3]. Large amount of energy is also needed to reach this high pressure.

\subsubsection{Liquefying hydrogen}

Storing hydrogen in a liquid state has higher energy density than compressing hydrogen. It is a technology used in NASA's Space Shuttle programs. However, the drawbacks with liquefying hydrogen are the big energy requirement for hydrogen liquefaction, hydrogen boil-off, and tank cost.

As shown in the primitive phase diagram for hydrogen (Figure 1.3), there is no liquid phase above the critical temperature, $33 \mathrm{~K}[7,8]$. To exist as a liquid, hydrogen must be cooled to its critical point (33 K). Liquid hydrogen is stored in cryogenic tanks at $20.28 \mathrm{~K}$ at ambient pressure. It needs large amount of energy to liquefy hydrogen from room temperature to this low temperature. Moreover, all of the components for storage and delivery of the liquid hydrogen must also be cooled to this low temperature, which leads to a further energy cost.

Because there is no liquid phase of hydrogen existing above its critical temperature $(33 \mathrm{~K})$, liquid hydrogen can only be stored at open systems. Otherwise, in a closed storage system, the hydrogen pressure at room temperature could reach to 
about $10^{4}$ bar [7]. Thus, continuous boil-off of liquid hydrogen is unavoidable. Therefore, liquefying hydrogen for on-board use is not an energy efficient method.

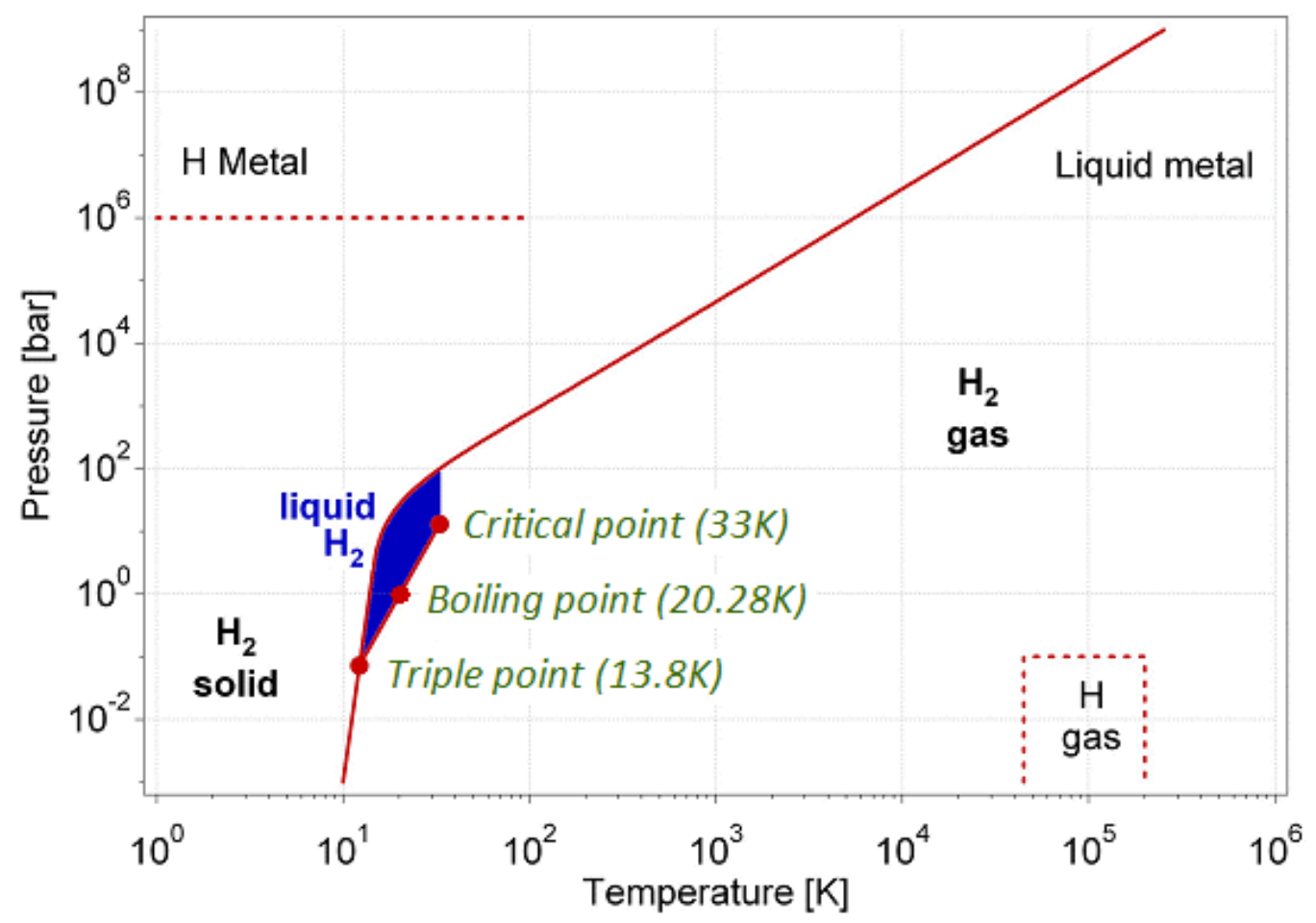

Figure 1.3 Primitive phase diagram for hydrogen. Liquid hydrogen only exists within the blue area which is between $13.8 \mathrm{~K}$ and $33 \mathrm{~K}[7,8]$. (With permission from Springer)

For those reasons, hydrogen storage in solid materials is now seen as the safest and most effective way of routinely handling hydrogen for transportation application. Therefore, the emphasis of hydrogen storage was and will be focused on storage in solid materials. 


\subsubsection{Physical adsorption}

Like all other gases, hydrogen will be adsorbed onto solid surfaces via weak Van der Waals force $(1-10 \mathrm{~kJ} / \mathrm{mol} \mathrm{H})$. Because of the weak interaction, thermal energy at room temperature is enough to desorb the majority of hydrogen from the surface. A significant physisorption is only observed at low temperatures $(<273 \mathrm{~K})$. Liquid nitrogen (boiling point $77 \mathrm{~K}$ ) is often used as coolant to maximize this interaction.

Materials for hydrogen storage via physisorption are typically solids with high surface area such as zeolites [9], activated carbons [10], metal-organic frameworks (MOFs) $[11,12]$ etc. The amount of adsorbed hydrogen is proportional to the BET surface area (total surface area based on the multipoint Brunauer, Emmett and Teller method) of the materials at low temperature $(77 \mathrm{~K})$.

The hydrogen capacity via physical adsorption is low at ambient temperature. The maximum absorption capacity for hydrogen on carbon materials is $2 \mathrm{wt} \%$. The adsorption capacity of zeolites at $77 \mathrm{~K}$ is typically below $2 \mathrm{wt} \%$. By modifying the

organic linkers, the pore size and effective surface area can be tailored quite effectively. For example, hydrogen adsorption capacities of up to $7.5 \mathrm{wt} \%$ at $77 \mathrm{~K}$ have been obtained for MOF-177 [13, 14]. 


\subsubsection{Metal hydrides}

Metal hydrides can be generated by the reaction of hydrogen and many metals and alloys at elevated temperature. For some cases, the formation of metal hydrides does not change the original structure of these metals. These hydrides are called interstitial hydrides, e.g. $\mathrm{PdH}, \mathrm{LaNi}_{5} \mathrm{H}_{\mathrm{x}}$ and $(\mathrm{Vi}-\mathrm{Ti}-\mathrm{Fe}) \mathrm{H}_{2}$. For other cases, the formation of metal hydrides changes the original metal structure, e.g. $\mathrm{MgH}_{2}$ and $\mathrm{AlH}_{3}$.

For many binary metal hydrides, the thermodynamics of $\mathrm{H}$ bonding is either too strong or too weak. For example, the binding energy of $\mathrm{AlH}_{3}$ is so weak (7.6 $\left.\mathrm{kJ} / \mathrm{mol} \mathrm{H}_{2}[15]\right)$ that it is impossible to generate $\mathrm{AlH}_{3}$ directly from the reaction of $\mathrm{Al}$ and $\mathrm{H}_{2}$ at moderate pressure. While the binding energy of $\mathrm{MgH}_{2}$ is so strong (62.3 $\left.\mathrm{kJ} / \mathrm{mol} \mathrm{H}_{2}[16]\right)$ that it needs $\sim 290{ }^{\circ} \mathrm{C}$ to release hydrogen at $1 \mathrm{~atm}$.

In order to obtain intermediate thermodynamic affinities for hydrogen, Researchers $[17,18]$ combined strong hydride forming elements A with weak hydride forming elements B to form alloys. Typical alloys for hydrogen storage include $\mathrm{AB}_{5}, \mathrm{AB}_{2}, \mathrm{AB}$, and, $\mathrm{A}_{2} \mathrm{~B}$. The latter element $\mathrm{B}$ is often $\mathrm{Ni}$ due to its excellent hydrogen dissociation performance [7]. For example, $\mathrm{LaH}_{2}$ (binding energy 208 $\mathrm{kJ} / \mathrm{mol} \mathrm{H}_{2}$ ) and $\mathrm{NiH}$ (binding energy $8.8 \mathrm{~kJ} / \mathrm{mol} \mathrm{H}_{2}$ ) can form $\mathrm{LaNi}_{5} \mathrm{H}_{6^{+}}$(binding energy $30.9 \mathrm{~kJ} / \mathrm{mol} \mathrm{H}_{2}$ ) [19].

Metal hydrides have larger volumetric hydrogen density than hydrogen gas or liquid hydrogen [2]. However, the gravimetric hydrogen density is limited to less than 3 weight $\%$ for metal hydrides working around ambient temperature and 
atmospheric pressure because they consist of transition metals. Therefore, it is still a challenge to explore metal hydrides for onboard hydrogen storage usage.

\subsubsection{Complex hydrides}

Group I and II salts of $\left[\mathrm{AlH}_{4}\right]^{-},\left[\mathrm{NH}_{2}\right]^{-},\left[\mathrm{BH}_{4}\right]^{-}$are referred to as "complex hydrides" because in which hydrogen is covalently bonded to central atoms to form "complex" anions in contrast to interstitial hydrides [20].

Hydrogen storage in light weight complex hydride can meet the DOE gravimetric and volumetric capacities targets. Many complex hydrides even show very high gravimetric and volumetric hydrogen densities. For example, the gravimetric and volumetric hydrogen densities for $\mathrm{LiBH}_{4}$ are 18.5 wt $\%$ and 120

$\mathrm{kg} / / \mathrm{m}^{3}$ [21]; for $\mathrm{Al}\left(\mathrm{BH}_{4}\right)_{3}$ are17 $\mathrm{wt} \%$ and $150 \mathrm{~kg} / \mathrm{m}^{3}$ [22]. However, the slow kinetics, high hydrogen release temperature and low charge and discharge rates are still challenges for mobile applications [23]. $\mathrm{LiBH}_{4}$ and $\mathrm{NaBH}_{4}$ are most promising candidates among the known borohydrides which can be potentially used for onboard applications due to their high hydrogen densities. Nevertheless, their low dynamics of hydrogen release is still a big problem associated with these systems [23].

Most complex hydrides change their morphology of particles and cannot maintain their original structure after the hydrogen absorption/desorption cycles [24]. Therefore, the reversibility is also a problem. 


\subsubsection{Clathrate}

Recently, hydrogen storage in clathrate hydrogen hydrates was explored [2530]. Hydrogen storage in this type of material is achieved by capturing hydrogen in $\mathrm{H}_{2} \mathrm{O}$-cages, instead of chemical reaction or physical adsorption. Because the hydrogen hydrates are neither flammable nor corrosive, they provide a safe and environmentally-friendly material to store hydrogen. However, it still remains a challenge to employ hydrogen hydrates as practical hydrogen storage materials. For example, formation of hydrogen hydrate is a slow process. The permanent cooling, which is necessary to keep hydrogen hydrates stable, may be another issue.

\subsection{Lithium nitride for hydrogen storage}

As early as 1910, Dafert and Miklauz found that $\mathrm{Li}_{3} \mathrm{~N}$ and $\mathrm{H}_{2}$ generated $\mathrm{Li}_{3} \mathrm{NH}_{4}$ at $220-250{ }^{\circ} \mathrm{C}$ and $\mathrm{Li}_{3} \mathrm{NH}_{4}$ can be partially decomposed to release $\mathrm{H}_{2}$ [31]. The next year, Ruff, H. Goerges identified that $\mathrm{Li}_{3} \mathrm{NH}_{4}$ is a mixture of $\mathrm{LiNH}_{2}$ and $2 \mathrm{LiH}$ [32]. Consequently, the reversible process of the hydrogenation of $\mathrm{Li}_{3} \mathrm{~N}$ and the dehydrogenation of the hydrogenated $\mathrm{Li}_{3} \mathrm{~N}$ can be used for hydrogen storage. Although $\mathrm{Li}_{3} \mathrm{~N}$ can be used as hydrogen storage material, it did not attract any attention for almost a century. Since 2002 , the interests of $\mathrm{Li}_{3} \mathrm{~N}$ as a hydrogen storage material have been activated [33-51].

The Li-N-H system for hydrogen storage is based on the following hydrogenation and dehydrogenation process [33]: 


$$
\mathrm{Li}_{3} \mathrm{~N}+2 \mathrm{H}_{2} \leftrightarrow \mathrm{Li}_{2} \mathrm{NH}+\mathrm{LiH}+\mathrm{H}_{2} \leftrightarrow \mathrm{LiNH}_{2}+2 \mathrm{LiH}
$$

The enthalpy changes of the dehydrogenation process are shown as follows:

$$
\begin{array}{ll}
\mathrm{LiNH}_{2}+\mathrm{LiH}=\mathrm{Li}_{2} \mathrm{NH}+\mathrm{H}_{2} & \Delta H=44.63 \mathrm{~kJ} / \mathrm{mol} \mathrm{H} \\
\mathrm{Li}_{2} \mathrm{NH}+\mathrm{LiH}=\mathrm{Li}_{3} \mathrm{~N}+\mathrm{H}_{2} & \Delta H=148.07 \mathrm{~kJ} / \mathrm{mol} \mathrm{H}_{2}
\end{array}
$$

Because further dehydrogenation of $\mathrm{Li}_{2} \mathrm{NH} / \mathrm{LiH}$ back to $\mathrm{Li}_{3} \mathrm{~N}$ is difficult (as we can see from the big enthalpy change of Reaction 1.3), the attention was focused on Reaction 1.2 as a reversible process, which provides $6.8 \mathrm{wt} \%$ hydrogen storage capacity [52].

Hydrogen absorption and desorption by $\mathrm{Li}_{2} \mathrm{NH}$ (Reaction 1.2) was measured with a commercial pressure-composition-temperature (PTC) automatic measuring system [53]. The results are shown in Figure 1.4. 


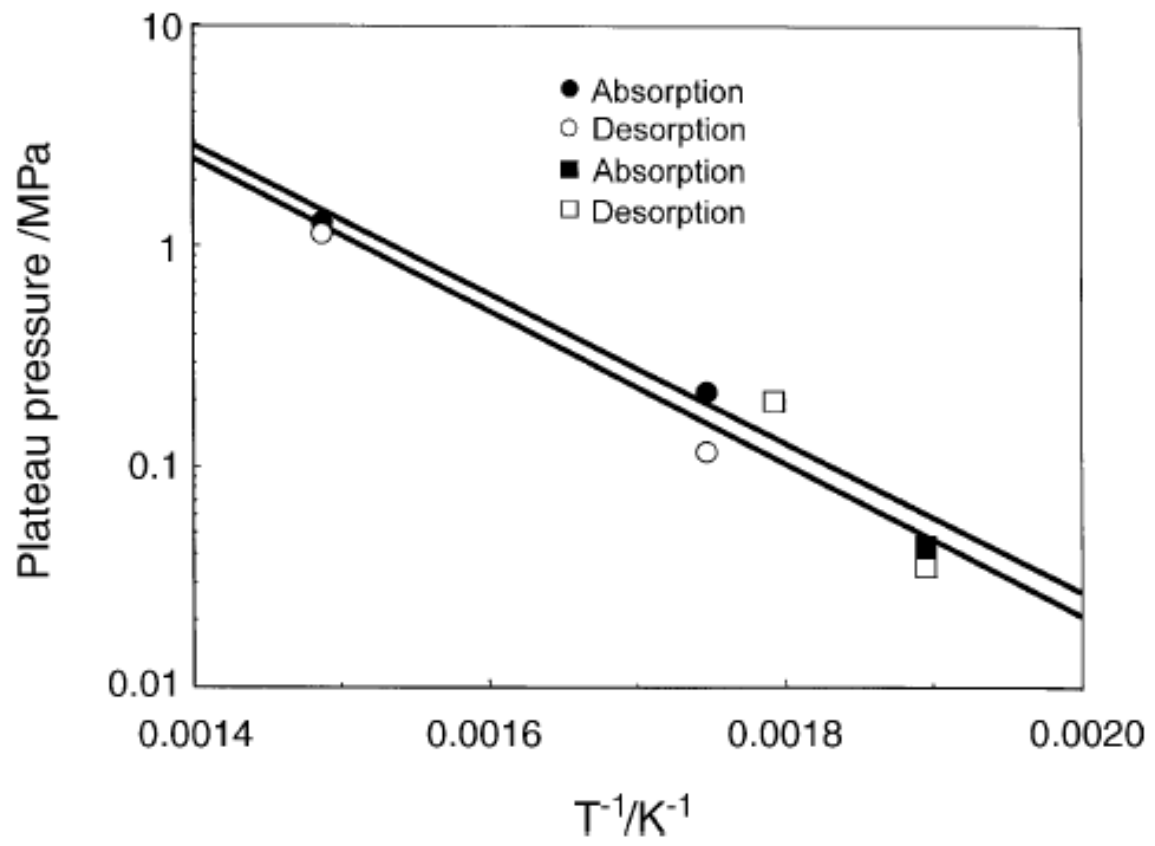

Figure 1.4 Logarithm of dissociation pressure vs. reciprocal of absolute temperature [53]. (With permission from Elsevier)

The equations of hydrogen absorption and desorption based on Figure 1.4 are [53]:

$$
\begin{aligned}
& \ln P=-\frac{7760}{\mathrm{~T}}+14.2 \text { (absorption) } \\
& \ln P=-\frac{8010}{\mathrm{~T}}+14.4 \text { (desorption) }
\end{aligned}
$$

Assuming that $\mathrm{H}_{2}$ absorption and desorption reaction paths are the same, by averaging Equation (1.4) and (1.5), we can get:

$$
\ln P=-\frac{7885}{\mathrm{~T}}+14.3
$$


Through Equation (1.6), we can calculate the enthalpy and entropy change of Reaction (1.2): $\Delta \mathrm{H}=65.6 \mathrm{~kJ} / \mathrm{mol} \mathrm{H}_{2}$ and $\Delta \mathrm{S}=119 \mathrm{~J} / \mathrm{mol} \mathrm{H}_{2} \cdot \mathrm{K}$. The value of enthalpy obtained by this experiment is different from the one by theoretically calculation $\Delta H$ $=44.63 \mathrm{~kJ} / \mathrm{mol} \mathrm{H}_{2}$ probably because the errors of each method.

By Equation (1.6), we can draw a plot of the equilibrium hydrogen pressure and reaction temperature of the hydrogenation and dehydrogenation of $\mathrm{Li}_{2} \mathrm{NH} / \mathrm{LiH}$ system (Reaction 1.2) as shown in Figure 1.5.

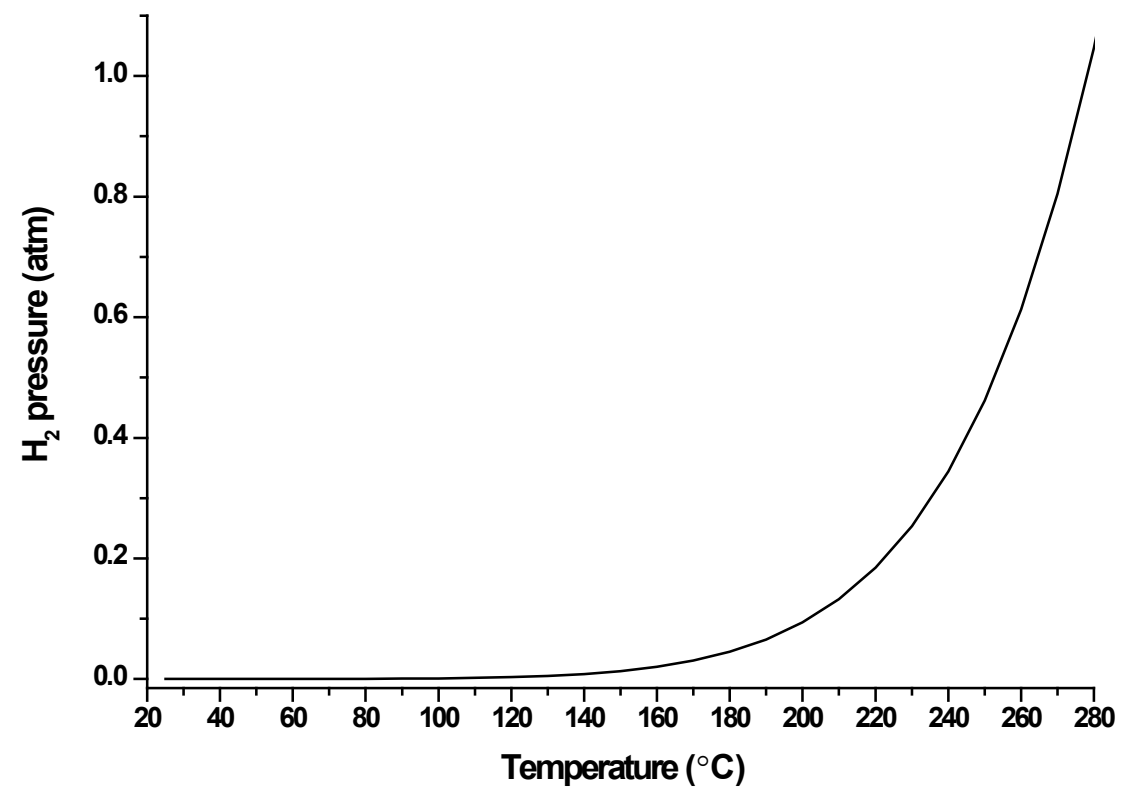

Figure 1.5 Equilibrium hydrogen pressure and reaction temperature of Reaction (1.2).

From Figure 1.5 we know that when the combination of hydrogen pressure and reaction temperature is below the curve, the equilibrium of Reaction (1.2) will 
move forward, namely, the dehydrogenation is feasible. In contrast, when the combination of hydrogen pressure and reaction temperature is above the curve, the equilibrium of Reaction (1.2) will move backward, namely, the hydrogenation is feasible.

\subsection{Lithium nitride crystal structure and optical property}

\subsubsection{Crystal structure}

$\mathrm{Li}_{3} \mathrm{~N}$ is the only stable alkali metal nitride [54-56]. The commercial $\mathrm{Li}_{3} \mathrm{~N}$ used was a two-phase mixture of $\alpha-\mathrm{Li}_{3} \mathrm{~N}$ and $\beta-\mathrm{Li}_{3} \mathrm{~N}$. $\alpha-\mathrm{Li}_{3} \mathrm{~N}$ can be prepared by direct combination of elemental lithium with nitrogen gas at $400{ }^{\circ} \mathrm{C}$ [57]. Its structure was first evaluated by Zintl and Brauer [58] and later revised by Rabenau and Schulz [59]. They revealed that the structure of $\alpha$ phase is hexagonal with P6/mmm space group and lattice constants $\mathrm{a}=3.648(1) \AA$ and $\mathrm{c}=3.875(1) \AA(\mathrm{Z}=1)$ $[59,60] . \alpha-\mathrm{Li}_{3} \mathrm{~N}$ crystal structure consists of two types of layers: in the $\mathrm{Li}_{2} \mathrm{~N}^{-}$layers, the lithium atoms $\mathrm{Li}(1)$ are arranged in a graphite like structure with the nitrogen atoms at the center of the hexagons; in the pure lithium layers, the pure $\operatorname{Li}(2)$ are on the top of the nitrogen atoms. $\alpha-\mathrm{Li}_{3} \mathrm{~N}$ is known to have an exceptionally large $\mathrm{Li}$ ionic conductivity [61-65]. Its conductivity is caused by intrinsic defects $(1-2 \% \mathrm{Li}$ vacancies) in the $\alpha-\mathrm{Li}_{2} \mathrm{~N}$ layers [66]. Due to the defects within the $\mathrm{Li}_{2} \mathrm{~N}$ layers, the structure of $\alpha-\mathrm{Li}_{3} \mathrm{~N}$ is packed loosely, and consequently it could be expected to 
undergo a pressure-induced phase transformation. Indeed, $\beta-\mathrm{Li}_{3} \mathrm{~N}$ can be produced by the pressure $(\sim 0.5 \mathrm{GPa})$ induced phase transformation of $\alpha-\mathrm{Li}_{3} \mathrm{~N}[67,68]$. This phase possesses a hexagonal structure in the $\mathrm{P} 6_{3} / \mathrm{mmc}$ space group with $\mathrm{a}=3.552(1)$ $\AA$ and $\mathrm{c}=6.311(3) \AA(\mathrm{Z}=2)[69]$ in which pure-lithium layers alternate $\mathrm{LiN}$ layers as opposed to the $\mathrm{Li}_{2} \mathrm{~N}$ layers in $\alpha$ phase.

Since the phase transformation from $\alpha-\mathrm{Li}_{3} \mathrm{~N}$ to $\beta-\mathrm{Li}_{3} \mathrm{~N}$ takes place at the relatively low pressure of $0.5 \mathrm{GPa}$, it can hardly be ruled out that at least a partial $\beta$ $\mathrm{Li}_{3} \mathrm{~N}$ can be formed by grinding a- $\mathrm{Li}_{3} \mathrm{~N}$ in a mortar [69]. Mechanically ball milling commercial $\mathrm{Li}_{3} \mathrm{~N}$ can also transform $\alpha-\mathrm{Li}_{3} \mathrm{~N}$ to $\beta-\mathrm{Li}_{3} \mathrm{~N}$ due to the high pressure produced by the strong striking between the ball and the jar wall [70]. Heat treatment $\left(\sim 500^{\circ} \mathrm{C}\right)$ of $\beta-\mathrm{Li}_{3} \mathrm{~N}$ can lead the phase transformation of $\beta-\mathrm{Li}_{3} \mathrm{~N}$ back to $\alpha-\mathrm{Li}_{3} \mathrm{~N}[70,71]$. The $\beta-\mathrm{Li}_{3} \mathrm{~N}$ phase remains stable up to $35 \mathrm{Gpa}$.

The third solid phase of $\mathrm{Li}_{3} \mathrm{~N}, \gamma-\mathrm{Li}_{3} \mathrm{~N}$, exist at ultra high pressure. Theoretical calculations predicted the phase transformation from $\beta-\mathrm{Li}_{3} \mathrm{~N}$ to a cubic structure P $\overline{4} 3 \mathrm{~m}$ at $37.9 \mathrm{Gpa}[72]$ or $\mathrm{Fm} \overline{3} \mathrm{~m}$ at $27.6 \pm 5.4 \mathrm{Gpa}[68]-\gamma-\mathrm{Li}_{3} \mathrm{~N}$. Furthermore, experimental evidence showed that $\beta-\mathrm{Li}_{3} \mathrm{~N}$ indeed transforms to a cubic structure $(\gamma$ $\mathrm{Li}_{3} \mathrm{~N}$ ) in the pressure range of $36-45 \mathrm{Gpa}[73] . \gamma-\mathrm{Li}_{3} \mathrm{~N}$ possesses a FCC structure in the $\mathrm{Fm} \overline{3} \mathrm{~m}$ space group with a $=4.976 \AA$ and remains stable up to $200 \mathrm{Gpa}$ [73]. 


\subsubsection{Optical property}

The electronic structure and energy gap of $\mathrm{Li}_{3} \mathrm{~N}$ have been evaluated experimentally [71, 74, 75] and theoretically [76-82]. Brendecke and Bludau investigated the optical absorption of single crystal $\alpha-\mathrm{Li}_{3} \mathrm{~N}$ with incident light perpendicular and parallel to the c-direction $[74,75]$. Their results showed $\alpha-\mathrm{Li}_{3} \mathrm{~N}$ with anisotropic behavior of optical absorption: $\mathrm{E} / / \mathrm{c}=2.15 \mathrm{eV}$ at $4.2 \mathrm{~K}, \mathrm{E} / / \mathrm{c}=2.00 \mathrm{eV}$ at $300 \mathrm{~K}$, and $\mathrm{E} \perp \mathrm{c}=2.18 \mathrm{eV}$ at $4.2 \mathrm{~K}$ [74]. Our research group evaluated the optical properties of $\alpha$ and $\beta \mathrm{Li}_{3} \mathrm{~N}$ by ultraviolet-visible (UV-vis) absorption method and found that the energy gap of $\alpha$ and $\beta \mathrm{Li}_{3} \mathrm{~N}$ are $1.81 \pm 0.01$ and $2.14 \pm 0.01 \mathrm{eV}$, respectively [71]. In addition, ab initio calculations were employed to evaluate the band structure of $\mathrm{Li}_{3} \mathrm{~N}$. Kerker's self-consistent electronic structure calculation for $\alpha$ $\mathrm{Li}_{3} \mathrm{~N}$ predicted that the energy gap between the occupied valence band and the lowest excited band is $1 \mathrm{eV}$ [76]. Cui et al. carried out density functional calculations with the plane wave pseudopotential method, predicting that the energy gap of $\alpha$ $\mathrm{Li}_{3} \mathrm{~N}$ is $1.32 \mathrm{eV}$ at pressure of $0 \mathrm{GPa}$ [81]. This value is close to Kerker's result [76]. However, both of these theoretical values are smaller than the experimental ones: 2.2 $\mathrm{eV}$ by Brendecke and Bludau [74, 75] and $1.81 \pm 0.01 \mathrm{eV}$ by our group [71]. This discrepancy between theory and experiment is often observed for band-structure calculations of semiconductors [83]. Lazicki et al. performed first-principles electronic structure calculations and predicted that the energy gap of $\beta-\mathrm{Li}_{3} \mathrm{~N}$ is 1.5 $\mathrm{eV}$ [78]. This predicted value is smaller than our experimental value $(2.14 \pm 0.01 \mathrm{eV})$. This happened because theoretical calculations usually underestimate energy gaps of 
semi-conductors $[76,82]$. The energy gap of $\gamma-\mathrm{Li}_{3} \mathrm{~N}$ was predicted to be $5.5 \mathrm{eV}$ by Lazicki et al. [78] and $5.68 \mathrm{eV}$ by Cui et al. [81]. The big increase of the energy gap of the phase change from $\beta-\mathrm{Li}_{3} \mathrm{~N}$ to $\gamma-\mathrm{Li}_{3} \mathrm{~N}$ is in accordance with the optical change from the opaque $\beta$ to the transparent $\gamma$ phase [73].

\subsection{Lithium nitride halides structure and properties}

Lithium nitride halides $\mathrm{Li}_{3-2 \mathrm{y}} \mathrm{N}_{1-\mathrm{y}} \mathrm{X}_{\mathrm{y}}(\mathrm{X}=\mathrm{Cl}, \mathrm{Br}, \mathrm{I} ; 0<\mathrm{y}<1)$ compounds were first reported by Sattlegger and Hahn in 1964 [84, 85] and were subsequently studied widely [85-101]. Generally, the crystal structures of $\mathrm{Li}_{3-2 y} \mathrm{~N}_{1-y} \mathrm{X}_{\mathrm{y}}(\mathrm{X}=\mathrm{Cl}, \mathrm{Br}, \mathrm{I} ; 0<\mathrm{y}<1)$ can be understood as products of the reaction between $\alpha-\mathrm{Li}_{3} \mathrm{~N}$ and $\mathrm{LiX}(\mathrm{X}=\mathrm{Cl}, \mathrm{Br})$ in which the framework structure of $\alpha-\mathrm{Li}_{3} \mathrm{~N}$ is broken down into units of lower dimensionality [102]. $\mathrm{Li}_{9} \mathrm{~N}_{2} \mathrm{Cl}_{3}\left(2 \mathrm{Li}_{3} \mathrm{~N}\right.$ : $\left.3 \mathrm{LiCl}\right)$ possesses an anti-fluorite type structure with $10 \%$ of the lithium sites are vacancies, while the anion sites are almost completely randomly occupied by $\mathrm{N}$ and $\mathrm{Cl}[90]$. It shows more clearly by using formula $\left(\mathrm{Li}_{0.9} \square_{0.1}\right)_{2}\left(\mathrm{~N}_{0.4} \mathrm{Cl}_{0.6}\right)$ comparing with $\mathrm{Li}_{2} \mathrm{O}$ in which the sites are almost fully occupied [103]. The more vacancies of the $\mathrm{Li}$ sites of $\mathrm{Li}_{9} \mathrm{~N}_{2} \mathrm{Cl}_{3}$ than that of $\mathrm{Li}_{2} \mathrm{O}$ makes $\mathrm{Li}_{9} \mathrm{~N}_{2} \mathrm{Cl}_{3}$ a better ionic conductor than $\mathrm{Li}_{2} \mathrm{O}$ [103]. The ternary compounds $\mathrm{Li}_{11} \mathrm{~N}_{3} \mathrm{Cl}_{2}$ and $\mathrm{Li}_{9} \mathrm{~N}_{2} \mathrm{Cl}_{3}$ melt congruently at $705{ }^{\circ} \mathrm{C}$ and $710{ }^{\circ} \mathrm{C}$ respectively [88]. The incongruent melting points of compounds $\mathrm{Li}_{13} \mathrm{~N}_{4} \mathrm{Br}, \mathrm{Li}_{9} \mathrm{~N}_{2} \mathrm{Br}_{3}$ and $\mathrm{Li}_{6} \mathrm{NBr}_{3}$ decrease with increasing lithium bromide content: $600{ }^{\circ} \mathrm{C}$ for $\mathrm{Li}_{13} \mathrm{~N}_{4} \mathrm{Br}$, $510{ }^{\circ} \mathrm{C}$ for $\mathrm{Li}_{9} \mathrm{~N}_{2} \mathrm{Br}_{3}$ and $484{ }^{\circ} \mathrm{C}$ for $\mathrm{Li}_{6} \mathrm{NBr}_{3}$ [88]. Compound $\mathrm{Li}_{3 \mathrm{x}+1} \mathrm{~N}_{\mathrm{x}} \mathrm{I}$ 
$(1.89 \leq x \leq 2.76)$ shows the maximum congruent melting point of $775{ }^{\circ} \mathrm{C}$ while $\mathrm{Li}_{5} \mathrm{NI}_{2}$ melts congruently at $573{ }^{\circ} \mathrm{C}$ [88]. Lithium nitride halides have been proposed as solid electrolytes in practical battery applications due to their high $\mathrm{Li}^{+}$ion conductivity, negligible electronic conduction, and high enough thermodynamic decomposition voltage $[87,89]$.

Of all the lithium nitride halides $\mathrm{Li}_{3-2 \mathrm{y}} \mathrm{N}_{1-\mathrm{y}} \mathrm{X}_{\mathrm{y}}(\mathrm{X}=\mathrm{Cl}, \mathrm{Br}, \mathrm{I} ; 0<\mathrm{y}<1)$ stable compounds, $\mathrm{Li}_{13} \mathrm{~N}_{4} \mathrm{Br}$ shows the highest $\mathrm{Li}_{3} \mathrm{~N}$ to $\mathrm{LiX}(\mathrm{X}=\mathrm{Cl}, \mathrm{Br}, \mathrm{I})$ molar ratio. $\mathrm{Li}_{13} \mathrm{~N}_{4} \mathrm{Br}$ was prepared by annealing of the two binary compounds $\mathrm{Li}_{3} \mathrm{~N}$ and $\mathrm{LiBr}$ in the molar ratio of $4: 1$ at $400{ }^{\circ} \mathrm{C}$ for about 20 hours [86]. It was found that $\mathrm{Li}_{13} \mathrm{~N}_{4} \mathrm{Br}$ has a hexagonal symmetry with $a=7.417(1) \AA$ and $c=3.865(1) \AA[88] . \mathrm{Li}_{13} \mathrm{~N}_{4} \mathrm{Br}$ shows a phase transition at about $230{ }^{\circ} \mathrm{C}$ with a small enthalpy change of 0.927 $\mathrm{kJ} / \mathrm{mol}[88]$. The ionic conductivities of $\mathrm{Li}_{13} \mathrm{~N}_{4} \mathrm{Br}$ at 150 and $300{ }^{\circ} \mathrm{C}$ are $3.5 \times 10^{-6} \Omega^{-}$ ${ }^{1} \mathrm{~cm}^{-1}$ and $1.4 \times 10^{-3} \Omega^{-1} \mathrm{~cm}^{-1}$, respectively; the electronic conductivity of $\mathrm{Li}_{13} \mathrm{~N}_{4} \mathrm{Br}$ is negligible [90].

\subsection{Scope of this study}

Lithium nitride is an important material which can be used for hydrogen storage. The decompositions of lithium amide and lithium imide are important steps for hydrogen storage in $\mathrm{Li}_{3} \mathrm{~N}$. As far as our knowledge, the effect of anions (e.g. halide ions) on the decomposition have never been studied. 
Lithium nitride is also an important material which can be used for $\mathrm{CO}_{2}$ conversion, and electric charge storage. Lithium nitride halides are also significant materials which can be potentially used for batteries. Therefore, the chemical stability of lithium nitride and lithium nitride halides in air is very important for guiding how to deal with them while being used. As far as our knowledge, the chemical stability of lithium nitride and lithium nitride halides in air has never been studied.

Therefore, the objectives of this dissertation are to (1) evaluate the mechanism of the decomposition of lithium amide; (2) evaluate the mechanism of the decomposition of lithium imide; (3) examine the effect of anion promoter $\mathrm{Cl}^{-}$on the decomposition of lithium amide; (4) investigate the chemical stability of lithium nitride in air; and (5) investigate the chemical stability of lithium nitride halide $\mathrm{Li}_{13} \mathrm{~N}_{4} \mathrm{Br}$ in air. 


\section{Chapter 2 Decomposition of lithium amide *}

\subsection{Introduction}

Since $2002, \mathrm{Li}_{3} \mathrm{~N}$ has attracted much attention for hydrogen storage [33-51], which is based on the following hydrogenation and dehydrogenation [34]:

$$
\begin{array}{ll}
\mathrm{Li}_{3} \mathrm{~N}+\mathrm{H}_{2}=\mathrm{Li}_{2} \mathrm{NH}+\mathrm{LiH} & \Delta H=-148.07 \mathrm{~kJ} / \mathrm{mol} \mathrm{H}_{2} \\
\mathrm{Li}_{2} \mathrm{NH}+\mathrm{H}_{2}=\mathrm{LiNH}_{2}+\mathrm{LiH} & \Delta H=-44.63 \mathrm{~kJ} / \mathrm{mol} \mathrm{H}_{2}
\end{array}
$$

Because further dehydrogenation of $\mathrm{Li}_{2} \mathrm{NH} / \mathrm{LiH}$ back to $\mathrm{Li}_{3} \mathrm{~N}$ (the reverse direction of Reaction 2.1) is difficult, the attention was focused on Reaction 2.2 as a reversible process, which provides 6.8 wt $\%$ hydrogen storage capacity [52]. The dehydrogenation mechanism of $\mathrm{LiNH}_{2} / \mathrm{LiH}$ (Reaction 2.2) consists of two elementary steps with $\mathrm{NH}_{3}$ as intermediate species (Reaction 2.3 and Reaction 2.4) [34].

$$
\begin{array}{ll}
2 \mathrm{LiNH}_{2}=\mathrm{Li}_{2} \mathrm{NH}+\mathrm{NH}_{3} & \Delta H=84.1 \mathrm{~kJ} / \mathrm{mol} \mathrm{NH} \\
\mathrm{LiH}+\mathrm{NH}_{3}=\mathrm{LiNH}_{2}+\mathrm{H}_{2} & \Delta H=-39.47 \mathrm{~kJ} / \mathrm{mol} \mathrm{H}_{2}
\end{array}
$$

The reaction between $\mathrm{NH}_{3}$ and $\mathrm{LiH}$ (Reaction 2.4) is exothermic and ultra fast [34]. The decomposition of $\mathrm{LiNH}_{2}$ (Reaction 2.3) is the rate-determining step.

\footnotetext{
*The material contained in this chapter was previously published in the journal Industrial and Engineering Chemistry Research 2011, 50 (13), 8058-8064 by Junqing Zhang and Yun Hang Hu. See Appendix for documentation of permission to republish this material.
} 
We hypothesize that a new compound $\mathrm{Li}_{1.5} \mathrm{NH}_{1.5}$ may form during the decomposition of $\mathrm{LiNH}_{2}$. It is demonstrated through structural refinement from synchrotron X-ray diffraction that the mechanism of the transformation between $\mathrm{LiNH}_{2}$ and $\mathrm{Li}_{2} \mathrm{NH}$ during hydrogen cycling $\left(\mathrm{Li}_{3} \mathrm{~N}+2 \mathrm{H}_{2} \leftrightarrow \mathrm{Li}_{2} \mathrm{NH}+\mathrm{LiH}+\mathrm{H}_{2} \leftrightarrow\right.$ $\left.\mathrm{LiNH}_{2}+2 \mathrm{LiH}\right)$ occurs in a non-stoichiometric manner [104]. This means the formation of any intermediate species $\mathrm{Li}_{1+x} \mathrm{NH}_{2-\mathrm{x}}(0<\mathrm{x}<1)$ between $\mathrm{LiNH}_{2}$ and $\mathrm{Li}_{2} \mathrm{NH}$ is possible. Furthermore, density functional theory calculations predict that $\mathrm{Li}_{1.5} \mathrm{NH}_{1.5}$ is the most stable transition state between $\mathrm{LiNH}_{2}$ and $\mathrm{Li}_{2} \mathrm{NH}$ [105]. Therefore, it is reasonable for us to expect that the decomposition of $\mathrm{LiNH}_{2}$ to $\mathrm{Li}_{2} \mathrm{NH}$ is via the intermediate compound $\mathrm{Li}_{1.5} \mathrm{NH}_{1.5}$.

In this chapter, the systematical evaluation for the decompositions of $\mathrm{LiNH}_{2}$ was carried out. We evaluate how lithium amide $\left(\mathrm{LiNH}_{2}\right)$ decomposes and what intermediate species are formed during the decomposition by temperatureprogrammed decomposition and X-ray diffraction (XRD) techniques.

\subsection{Experiments}

\subsubsection{Sample preparations}

Lithium amide $\left(\mathrm{LiNH}_{2}\right)$ powder $(95 \%)$ which had been purchased from Sigma-Aldrich Chemical Co. was used without any further purification. 


\subsubsection{Temperature-programmed decomposition}

The temperature-programmed decomposition (TPD) experiments were performed as follows: A sample was loaded into a vertical quartz tube reactor, which was located in an electric tube furnace. The temperature of the reactor was increased to $850{ }^{\circ} \mathrm{C}$ at a rate of $5{ }^{\circ} \mathrm{C} / \mathrm{min}$. Argon $(30 \mathrm{~mL} / \mathrm{min})$ was employed as a carrier gas through the reactor to bring the gaseous products of the decomposition of the sample into a thermal conductivity detector (TCD, Figure 2.1) of Varian 3300 Gas Chromatograph, generating a TPD-TCD profile. Thermal conductivity is the property of a material to conduct heat.

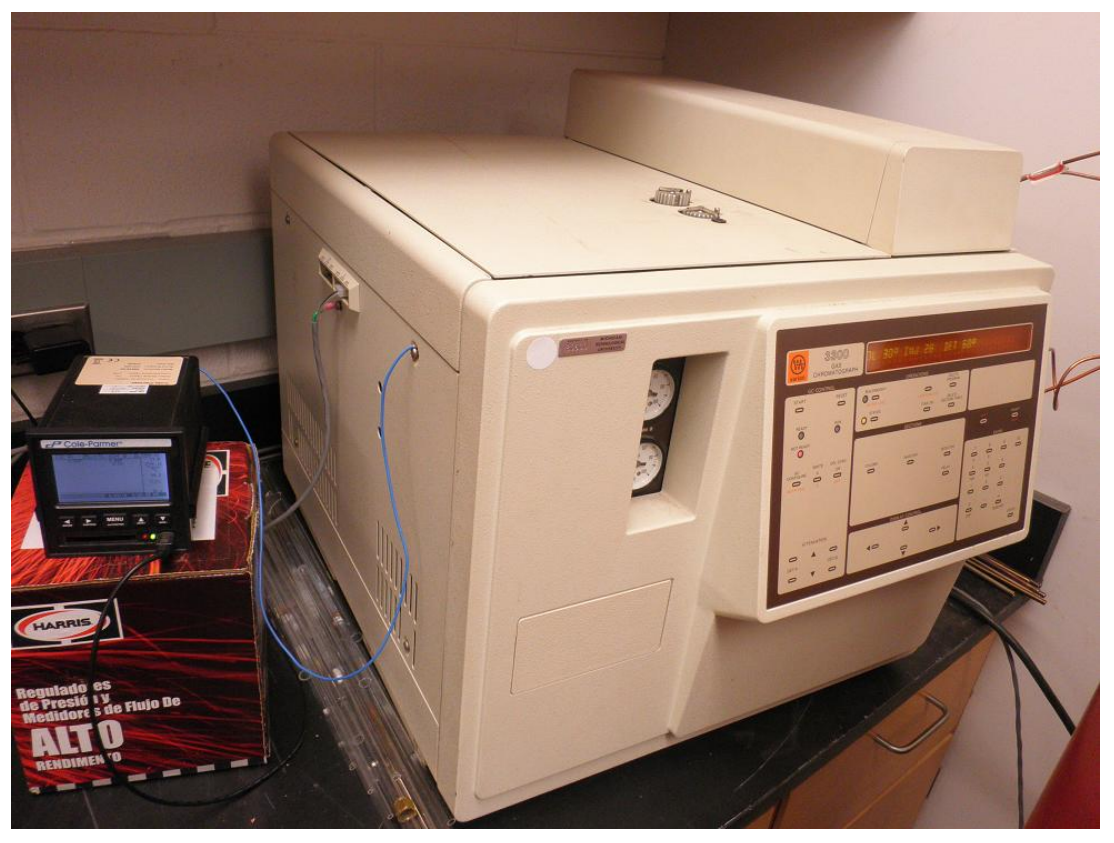

Figure 2.1 Thermal conductivity detector of Varian 3300 Gas Chromatograph. 
Furthermore, to determine all gas products except hydrogen, helium was used to carry the products from the TPD reactor into a mass spectrometer (HP 5970 series mass selective detector, Figure 2.2) instead of TCD detector, generating a TPD-MS profile. The masses from 16.7 to 17.7 were used to monitor $\mathrm{NH}_{3}$ and from 27.7 to 28.7 to detect $\mathrm{N}_{2}$.

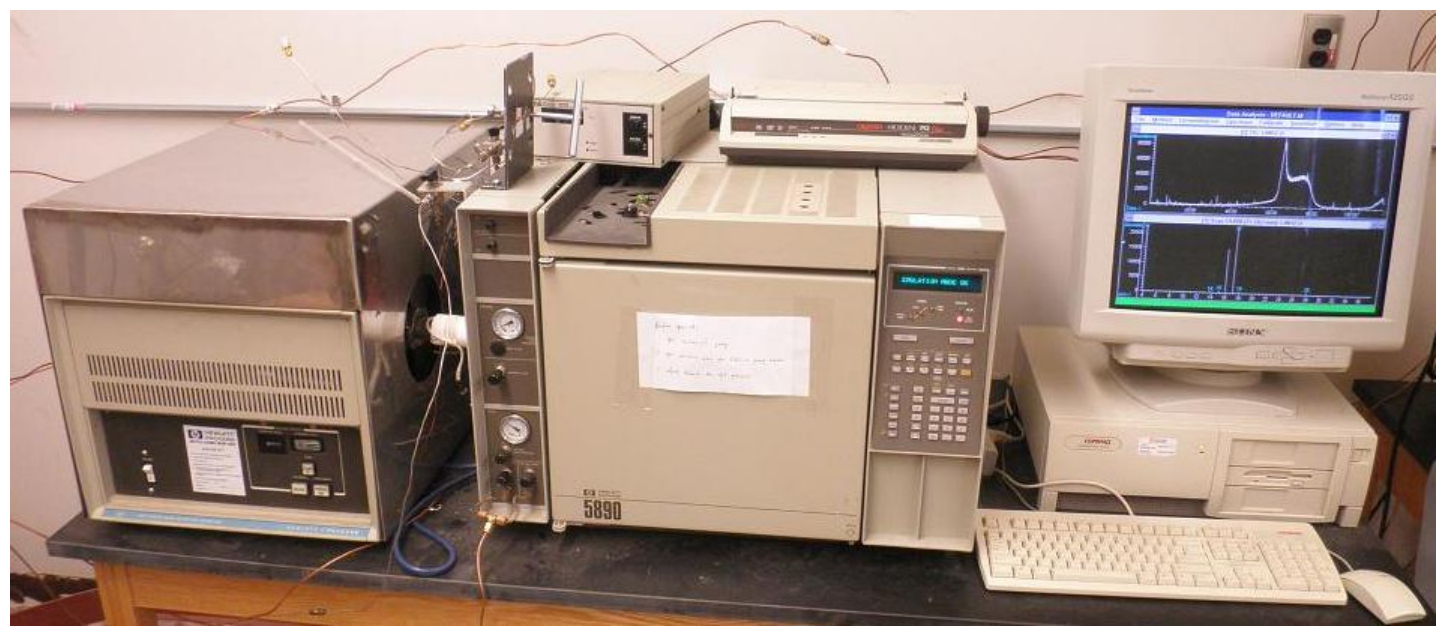

Figure 2.2 HP 5970 series mass selective detector.

\subsubsection{X-ray diffraction (XRD)}

A sample $(0.1 \mathrm{~g})$ was loaded into a vertical quartz tube reactor $(5-\mathrm{mm}$ diameter) located in an electric tube furnace. Argon $(30 \mathrm{~mL} / \mathrm{min})$ was introduced into the reactor at room temperature, followed by heating to a selected temperature at a rate of $5{ }^{\circ} \mathrm{C} / \mathrm{min}$ and then cooling down to room temperature. The obtained samples were subjected to XRD measurements, which were performed with a Scintag 
XDS2000 Powder Diffractometer equipped with a $\mathrm{Cu} \mathrm{K} \alpha$ source, at $45 \mathrm{kV}$ and 35 $\mathrm{mA}$ (Figure 2.3). The scanning speed was $1 \%$ min. Samples were covered with plastic wrap during the XRD measurements to prevent from absorbing $\mathrm{H}_{2} \mathrm{O}$ in air.

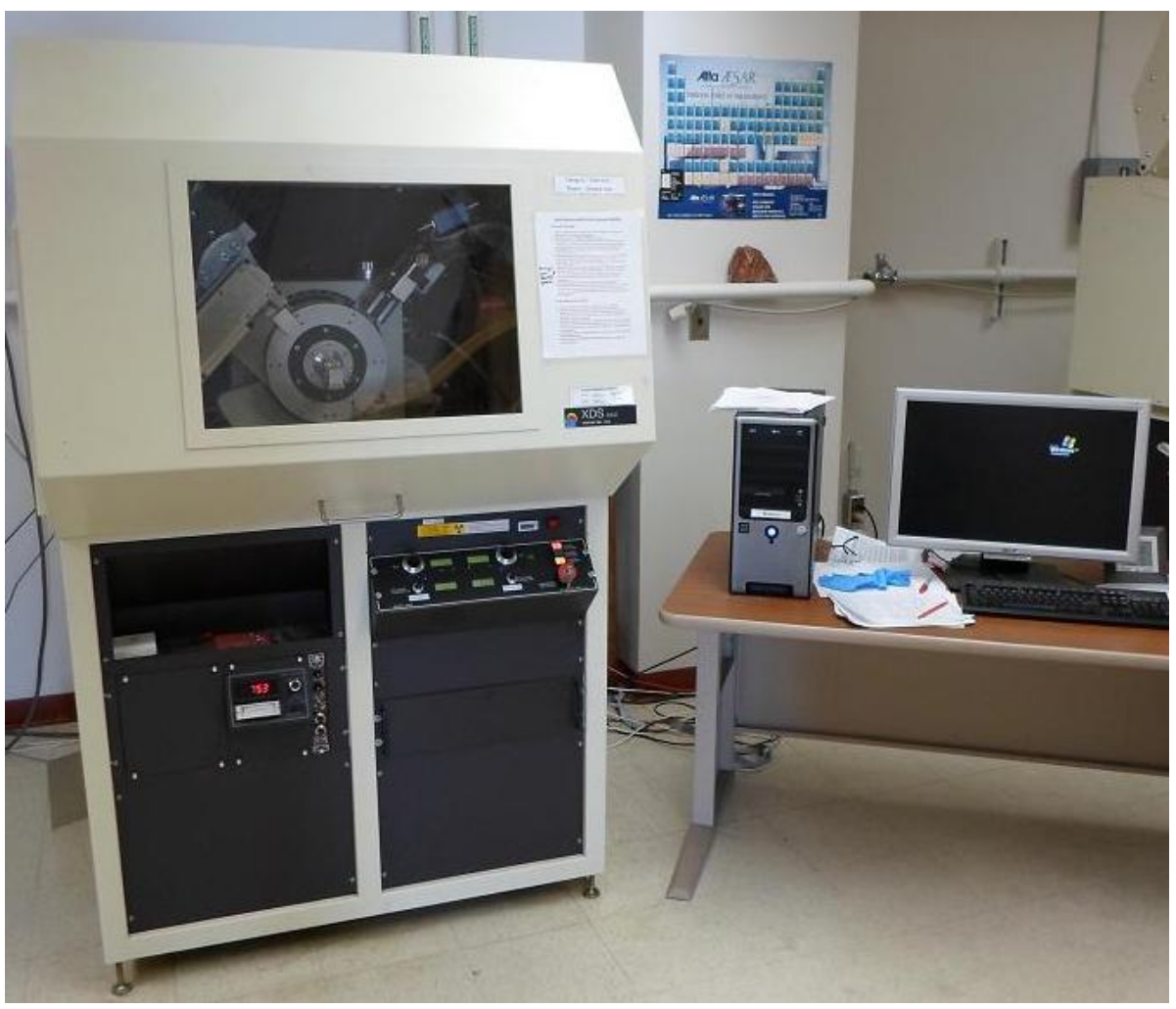

Figure 2.3 Scintag XDS2000 Powder Diffractometer.

\subsection{Results and discussion}

It is well-known that the decomposition of $\mathrm{LiNH}_{2}$ can produce $\mathrm{Li}_{2} \mathrm{NH}$ and $\mathrm{NH}_{3}[106,107]$. However, the answers for the two questions are still unknown: whether hydrogen is formed during the decomposition of $\mathrm{LiNH}_{2}$ and how $\mathrm{Li}_{2} \mathrm{NH}$ 
further decomposes. To clarify them, $\mathrm{LiNH}_{2}$ was subjected to temperatureprogrammed decompositions (TPD) with TCD and MS detectors.

As shown in Figure 2.4, one can see that the TPD-TCD and TPD-MS profiles are very similar. Furthermore, the TPD-MS profile showed that $\mathrm{NH}_{3}$ was formed in the temperature range of $160-470{ }^{\circ} \mathrm{C}$ and $\mathrm{N}_{2}$ produced between 550 and $800{ }^{\circ} \mathrm{C}$. However, hydrogen cannot be detected by the MS detector due to the limitation of the MS instrument. In contrast, the TPD-TCD provides total signals of all gases due to their different thermal conductivities from the carrier gas (Argon). In other words, all three possible gas products $\left(\mathrm{H}_{2}, \mathrm{NH}_{3}\right.$, and $\left.\mathrm{N}_{2}\right)$ can contribute to the peaks in the TPD-TCD profile. To clarify whether the peaks between 200 and $500{ }^{\circ} \mathrm{C}$ are associated with hydrogen, the gas products from the temperature-programmed decomposition of $\mathrm{LiNH}_{2}$ were cooled to $159 \mathrm{~K}$ before entering a TCD or MS detector. As a result, the peaks between 200 and $500{ }^{\circ} \mathrm{C}$ disappeared (Figure 2.5). The boiling temperatures of $\mathrm{H}_{2}(20.28 \mathrm{~K})$ and $\mathrm{N}_{2}(77.36 \mathrm{~K})$ are lower than the cooling temperature $(159 \mathrm{~K})$, whereas the melting temperature of $\mathrm{NH}_{3}(195 \mathrm{~K})$ is higher than the cooling temperature. Therefore, the disappearance of the peak between $200{ }^{\circ} \mathrm{C}$ and $500{ }^{\circ} \mathrm{C}$ should be due to the condensation of $\mathrm{NH}_{3}$. A small bump between 200 and $500{ }^{\circ} \mathrm{C}$ can be observed in Figure 2.5a. The further analysis of a gas chromatography (GC) equipped with TCD detector and a Porapak Q column revealed that the small bump is due to small amount of $\mathrm{H}_{2}$ and $\mathrm{N}_{2}$. In other words, the peaks at $330{ }^{\circ} \mathrm{C}$ in Figure $2.4 \mathrm{a}$ consist of mainly $\mathrm{NH}_{3}$ with a very little amount of $\mathrm{H}_{2}$ and $\mathrm{N}_{2}$. Such a negligible amount of $\mathrm{N}_{2}$ and $\mathrm{H}_{2}$ may be due to the decomposition 
of $\mathrm{NH}_{3}$.
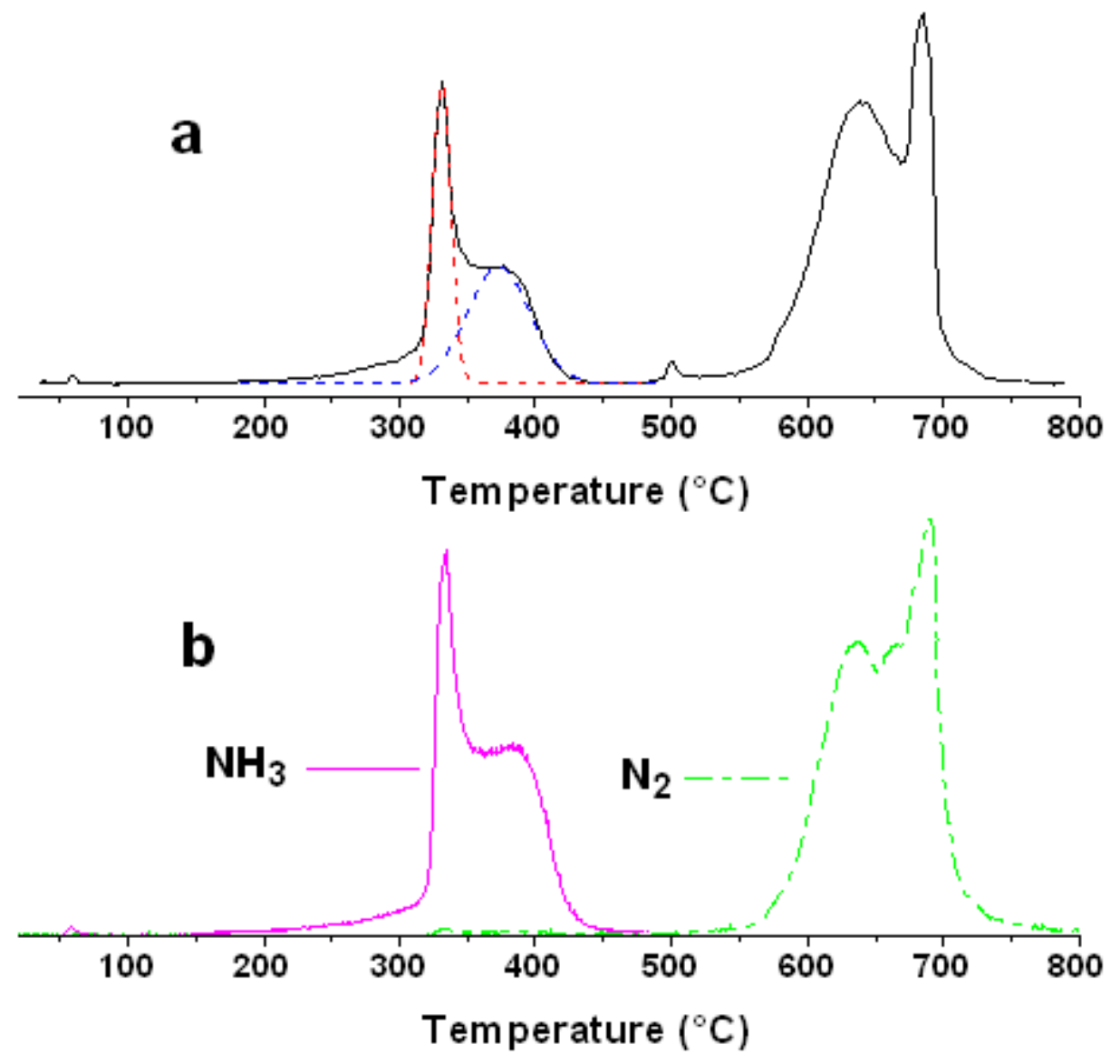

Figure 2.4 (a)TPD-TCD profile and (b) TPD-MS profile of pure $\mathrm{LiNH}_{2}$. 


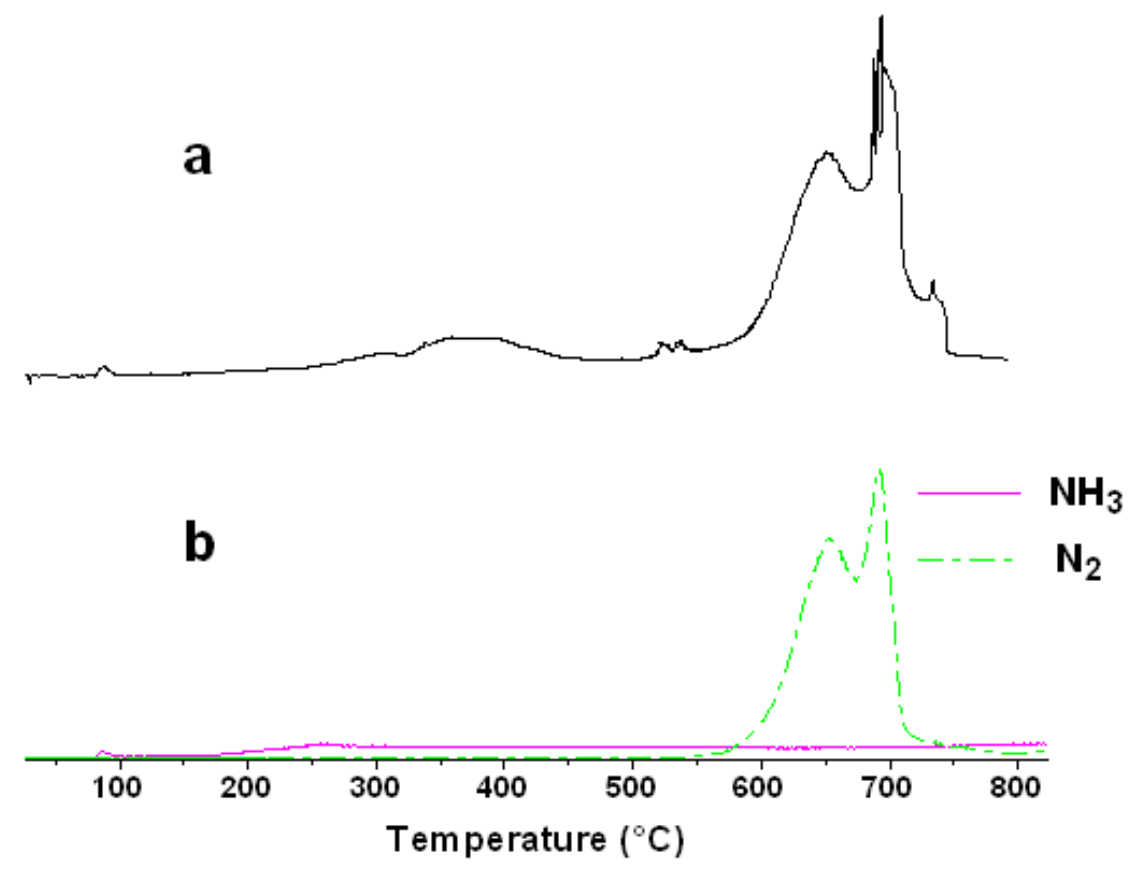

Figure 2.5 (a) TPD-TCD profile and (b) TPD-MS profile of $\mathrm{LiNH}_{2}$ with a cooler where produced gases were cooled to $159 \mathrm{~K}$ before entering TCD and MS detectors.

Furthermore, the solid products from the TPD process were analyzed by XRD. As shown in Figure 2.6, one can see that the solid product obtained after the decomposition of $\mathrm{LiNH}_{2}$ at $330{ }^{\circ} \mathrm{C}$ or above was $\mathrm{Li}_{2} \mathrm{NH}$. This indicates that the decomposition of $\mathrm{LiNH}_{2}$ produced $\mathrm{NH}_{3}$ and $\mathrm{Li}_{2} \mathrm{NH}$ between 200 and $500{ }^{\circ} \mathrm{C}$, which can be expressed by Equation 2.3. 


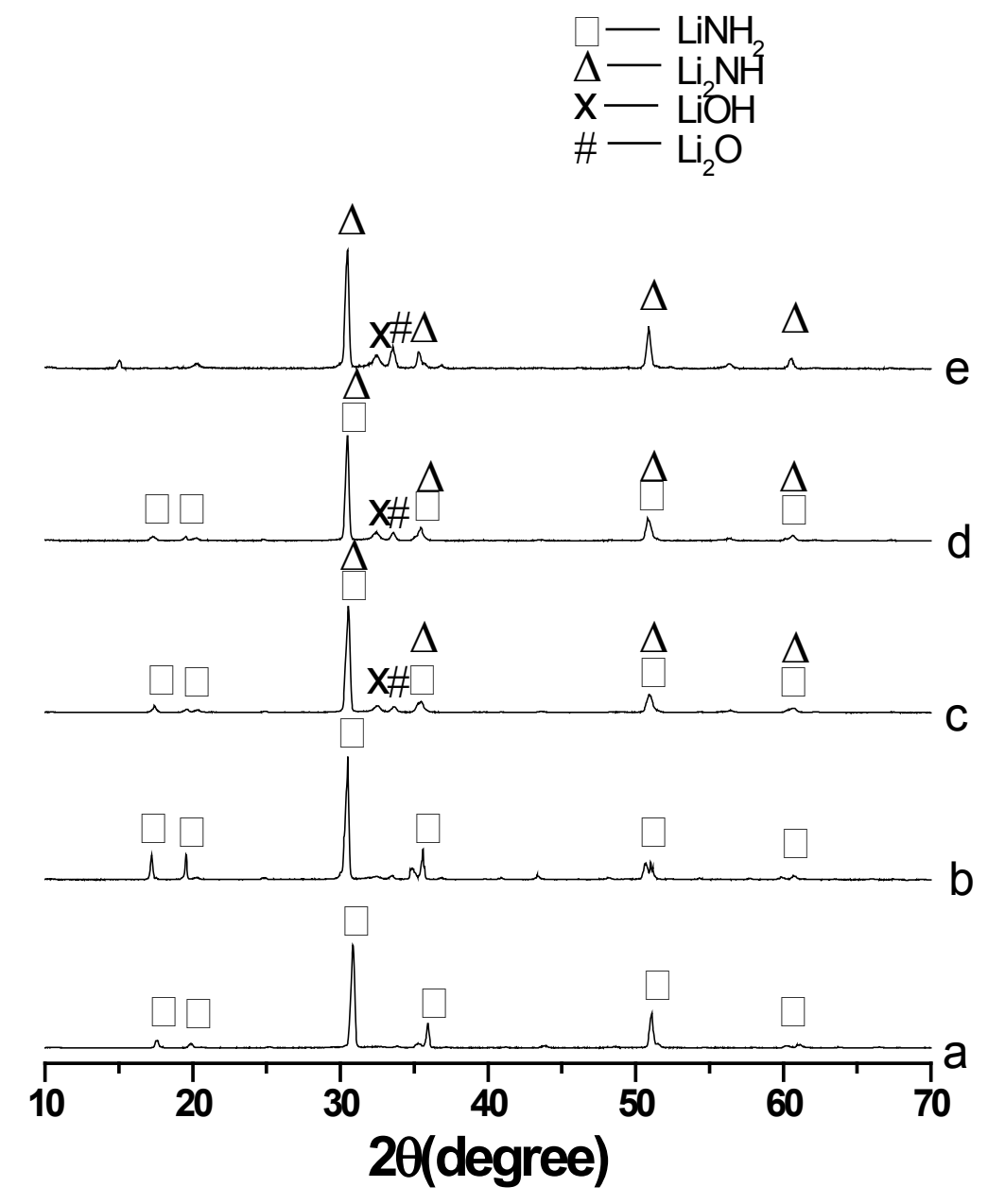

Figure 2.6 XRD patterns of the solid products from the TPD process of $\mathrm{LiNH}_{2}$ that was stopped at (a) room temperature, (b) $160{ }^{\circ} \mathrm{C}$, (c) $330{ }^{\circ} \mathrm{C}$, (d) $380{ }^{\circ} \mathrm{C}$, and (e) $520{ }^{\circ} \mathrm{C}$.

However, the decomposition process is not a single step, because there were two peaks (one at $330{ }^{\circ} \mathrm{C}$ and the other at $380{ }^{\circ} \mathrm{C}$ ) between 200 and $500{ }^{\circ} \mathrm{C}$ in the TPD profiles (Figure 2.4). This means that the two steps were involved in the decomposition of $\mathrm{LiNH}_{2}$ into $\mathrm{Li}_{2} \mathrm{NH}$ and $\mathrm{NH}_{3}$. In other words, a stable intermediate 
species $\mathrm{Li}_{1+x} \mathrm{NH}_{2-\mathrm{x}}(0<\mathrm{x}<1)$, which is between $\mathrm{LiNH}_{2}$ and $\mathrm{Li}_{2} \mathrm{NH}$, was formed as follows:

$$
\begin{aligned}
& (1+x) \mathrm{LiNH}_{2}=\mathrm{Li}_{1+\mathrm{x}} \mathrm{NH}_{2-\mathrm{x}}+\mathrm{x} \mathrm{NH} \\
& 2 \mathrm{Li}_{1+\mathrm{x}} \mathrm{NH}_{2-\mathrm{x}}=(1+\mathrm{x}) \mathrm{Li}_{2} \mathrm{NH}+(1-\mathrm{x}) \mathrm{NH}_{3}
\end{aligned}
$$

The ratio of $\mathrm{x}$ to $(1-\mathrm{x}) / 2$ equals to the ratio of the areas of peak 1 (at $330{ }^{\circ} \mathrm{C}$, corresponding to reaction 2.23) to peak 2 (at $380^{\circ} \mathrm{C}$, corresponding to reaction 2.24). The value (0.5) of $\mathrm{x}$ was obtained from the TPD profiles (overlapped peaks in Figure 2.4a were resolved by Gaussian function fitting to obtain their areas). Therefore, the intermediate species in the decomposition of $\mathrm{LiNH}_{2}$ is $\mathrm{Li}_{1.5} \mathrm{NH}_{1.5}$.

During the hydrogenation of $\mathrm{Li}_{3} \mathrm{~N}$, Weidner et al. detected a series of nonstoichiometric lithium imides [108], in which compositions can be changed from $\mathrm{Li}_{1.70} \mathrm{NH}_{1.30}$ to $\mathrm{Li}_{1.02} \mathrm{NH}_{1.98}[104,109]$. This would be dependent on the unique structure of $\mathrm{Li}_{2} \mathrm{NH}$. Juza et al. first reported that the crystal structure of lithium imide $\left(\mathrm{Li}_{2} \mathrm{NH}\right)$ is an anti-fluorite face centered cubic (fcc) structure [106]. Recently, Ohoyama et al. performed neutron powder diffraction experiments on $\mathrm{Li}_{2} \mathrm{NH}$ [110]. They confirmed the fcc structure. However, they refined the positions of hydrogen atoms, because there is not any fully occupied model representing experimental data. They found two partially occupied models that can explain the experimental data: Model I, in which every hydrogen is located at the $48 \mathrm{~h}$ site of the Fm $\overline{3} \mathrm{~m}$ space group and the site occupancy of hydrogen is only $8.7 \%$, and Model II, in which every 
hydrogen is located at the $16 \mathrm{e}$ site of the $\mathrm{F} \overline{4} 3 \mathrm{~m}$ space group and the site occupancy of hydrogen is $27 \%$. Furthermore, Noritake et al. [111] carried out synchrotron X-ray powder diffraction experiments and charge density analysis for the same sample as Ohoyama et al. used. They also confirmed the anti-fluorite structure. Based on the Rietveld analysis accomplished for various structure models on the expected hydrogen sites around $\mathrm{N}$ atom, they revealed that both the structure model with hydrogen located at the $48 \mathrm{~h}$ of the $\mathrm{Fm} \overline{3} \mathrm{~m}$ space group and the model with hydrogen located at the 96j site of the Fm $\overline{3} \mathrm{~m}$ space group can well match their experimental data. Other models were also proposed [112-115]. Although those models have some differences, they reached the same conclusion that sites for $\mathrm{N}$ and $\mathrm{Li}$ are fully occupied but sites for $\mathrm{H}$ only partially occupied. Each $\mathrm{H}$ atom randomly occupies the hydrogen sites around each N. In other words, the crystal structure of $\mathrm{Li}_{2} \mathrm{NH}$ is hydrogen disordered structure, which has huge number of unoccupied hydrogen sites. As a result, hydrogen can be introduced into the unoccupied hydrogen sites around $\mathrm{N}$ in stoichiometric lithium imide $\left(\mathrm{Li}_{2} \mathrm{NH}\right)$ to form a series of non-stoichiometric intermediate species between $\mathrm{LiNH}_{2}$ and $\mathrm{Li}_{2} \mathrm{NH}$. This can explain why the stable intermediate species $\left(\mathrm{Li}_{1.5} \mathrm{NH}_{1.5}\right)$ was observed during the thermal decomposition of $\mathrm{LiNH}_{2}$. Furthermore, very recently, Crivello et al. reported density functional theory calculations for intermediate Li-N-H compounds [105]. Their results showed that the formation of the intermediate $\mathrm{Li}_{1.5} \mathrm{NH}_{1.5}$ is possible and it should occupy a cubic Livacant-type structure, in which ordered $[\mathrm{NH}]^{2-}$ and $\left[\mathrm{NH}_{2}\right]^{-}$anions coexist. Therefore, 
our detected stable intermediate $\mathrm{Li}_{1.5} \mathrm{NH}_{1.5}$ compound is consistent with the DFT prediction.

\subsection{Conclusion}

The decomposition of $\mathrm{LiNH}_{2}$ was evaluated. It was found that the decomposition of $\mathrm{LiNH}_{2}$ produced $\mathrm{Li}_{2} \mathrm{NH}$ and $\mathrm{NH}_{3}$ via two-steps: $\mathrm{LiNH}_{2}$ into a stable intermediate species $\left(\mathrm{Li}_{1.5} \mathrm{NH}_{1.5}\right)$ and then into $\mathrm{Li}_{2} \mathrm{NH}$. This proved that the hypothesis a new compound $\mathrm{Li}_{1.5} \mathrm{NH}_{1.5}$ may form during the decomposition of $\mathrm{LiNH}_{2}$ is true. 


\section{Chapter 3 Decomposition of lithium imide *}

\subsection{Introduction}

$\mathrm{Li}_{2} \mathrm{NH}$ is a promising material for hydrogen storage with $6.8 \%$ reversible capacity [52]. However, the decomposition of lithium imide $\left(\mathrm{Li}_{2} \mathrm{NH}\right)$ has not been investigated. This prompts us to evaluate how $\mathrm{Li}_{2} \mathrm{NH}$ decomposes and what intermediate species is formed during the decomposition by temperatureprogrammed decomposition and X-ray diffraction (XRD) techniques as well as kinetic analysis.

$\mathrm{Li}_{4} \mathrm{NH}$, which is a stable compound, has been synthesized by the reaction of $\mathrm{LiNH}_{2}$ and $\mathrm{Li}_{3} \mathrm{~N}$ in liquid $\mathrm{Li}$ in the presence of $\mathrm{Fe}$ at $747{ }^{\circ} \mathrm{C}$ followed by slow cooling to $27{ }^{\circ} \mathrm{C}$ within $20 \mathrm{~h}$ [116], or by the reaction of $\mathrm{Li}_{3} \mathrm{~N}$ and $\mathrm{LiH}$ at $490{ }^{\circ} \mathrm{C}$ [117]. We hypothesize that $\mathrm{Li}_{4} \mathrm{NH}$ may be an intermediate compound during the decomposition of $\mathrm{Li}_{2} \mathrm{NH}$.

\footnotetext{
*The material contained in this chapter was previously published in the journal International Journal of Hydrogen Energy 2012, 37 (13), 10467-10472 by Junqing Zhang and Yun Hang Hu. See Appendix for documentation of permission to republish this material.
} 


\subsection{Experiments and kinetic calculation method}

\subsubsection{Sample preparations}

Lithium amide $\left(\mathrm{LiNH}_{2}\right)$ powder $(95 \%)$ and lithium nitride $\mathrm{Li}_{3} \mathrm{~N}$ powder $(\geq$ 99.5\%) which had been purchased from Sigma-Aldrich Chemical Co. were used without any further purification. Lithium imide $\left(\mathrm{Li}_{2} \mathrm{NH}\right)$ was prepared with thermal decomposition method: $\mathrm{LiNH}_{2}$ was located in a stainless steel tube reactor at room temperature under argon $(30 \mathrm{~mL} / \mathrm{min})$ flow, followed by increasing temperature to $500{ }^{\circ} \mathrm{C}$ at a rate of $5{ }^{\circ} \mathrm{C} / \mathrm{min}$.

\subsubsection{Temperature-programmed decomposition}

$5.5 \mathrm{mg} \mathrm{Li}_{2} \mathrm{NH}$ or $10 \mathrm{mg} \mathrm{Li} 3 \mathrm{~N}$ was loaded into a stainless steel tube reactor, which was located in an electric tube furnace. The temperature of the reactor was increased to $850^{\circ} \mathrm{C}$ at a rate of $5{ }^{\circ} \mathrm{C} / \mathrm{min}$ from room temperature. Argon $(30 \mathrm{~mL} / \mathrm{min})$ was employed as a carrier gas through the reactor to bring the gaseous products of the decomposition into a thermal conductivity detector (TCD, Figure 2.1), generating a TPD profile.

Furthermore, to determine all gas products except hydrogen, helium was used to carry the products from the TPD reactor into a mass spectrometer (HP Quadrupole, 5970 series mass selective detector, Figure 2.2) instead of TCD detector, generating 
a TPD-MS profile. The masses from 16.7 to 17.7 were used to monitor $\mathrm{NH}_{3}$ and from 27.7 to 28.7 to detect $\mathrm{N}_{2}$.

\subsubsection{X-ray diffraction (XRD)}

$0.1 \mathrm{~g} \mathrm{Li}_{2} \mathrm{NH}$ was loaded into a stainless steel tube reactor (5-mm diameter) located in an electric tube furnace. Argon $(30 \mathrm{~mL} / \mathrm{min})$ was introduced into the reactor at room temperature, followed by heating to a selected temperature at a rate of $5{ }^{\circ} \mathrm{C} / \mathrm{min}$ and then cooling down to room temperature. The obtained samples were subjected to XRD measurements, which were performed with a Scintag XDS2000 Powder Diffractometer equipped with a $\mathrm{Cu} \mathrm{K} \alpha$ source, at $45 \mathrm{kV}$ and $35 \mathrm{~mA}$ (Figure 2.3). The scanning speed was $1 \%$ min. Samples were covered with plastic wrap during the XRD measurements to prevent from absorbing $\mathrm{H}_{2} \mathrm{O}$ in air.

\subsubsection{Kinetic calculation method for TPD-TCD peaks}

Assuming temperature-programmed decomposition of a sample generate gas (gases) which is (are) uniform during the whole decomposition process. If TPD-TCD of the sample is taken, a peak signal will be generated recoding the decomposition process. A typical TPD-TCD profile is shown in Figure 3.1. 


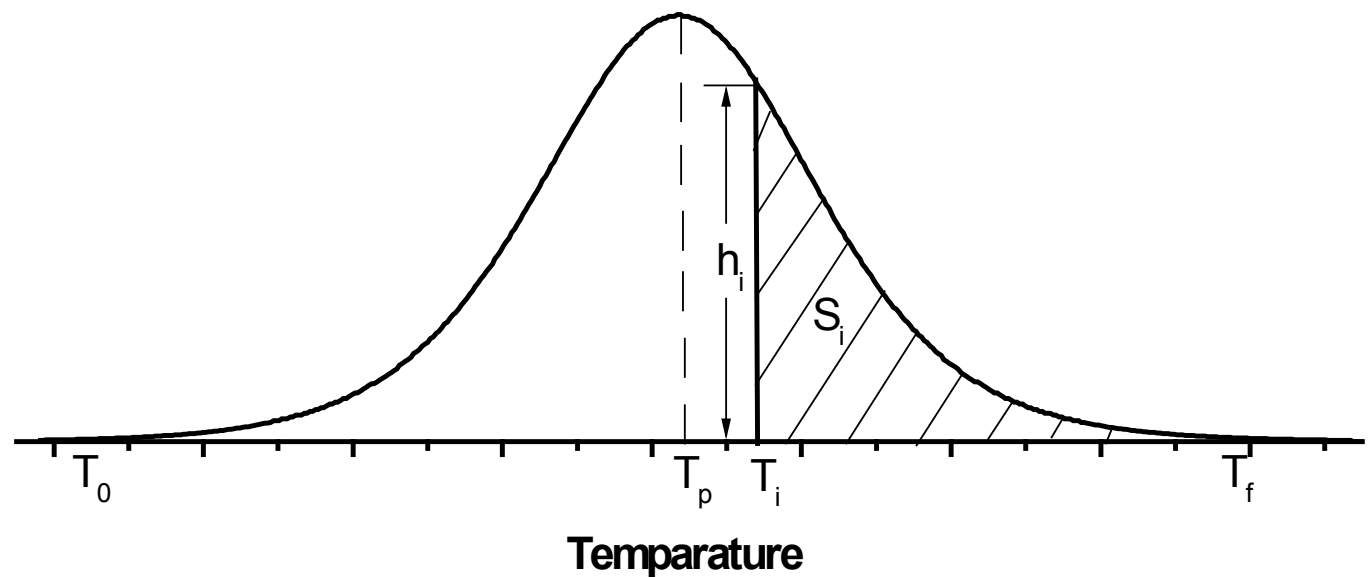

Figure 3.1 Typical TPD-TCD profile of a sample with a uniform gas product.

According to Polangi-Wagner model [118],

$$
-\frac{d N}{d t}=\mathrm{A} \exp \left(-\frac{E_{\mathrm{a}}}{\mathrm{RT}}\right) \mathrm{N}^{\mathrm{n}}
$$

where $\mathrm{N}$ is the amount of sample (mg) before decomposition; $\mathrm{t}$ the reaction time, A the pre-exponential factor, $E_{a}$ the decomposition activation energy, $n$ the decomposition order, $\mathrm{R}$ the gas constant, and $\mathrm{T}$ the absolute temperature.

When temperature increases linearly with time,

$$
T=T_{0}+\beta t
$$

where $T_{0}$ is initial decomposition temperature and $\beta$ heating rate. From Equation 3.6, one can obtain

$$
d t=\frac{d T}{\beta}
$$

Because the amount of sample is proportional to the area of the peak, 


$$
N=a S_{i}
$$

where $a$ is the proportionality constant and $S_{i}$ the area of the peak from $T_{i}$ to $T_{f}$ (where $T_{f}$ is the ending temperature of the peak)

The combination of Equation 3.5 with Equations 3.7 and 3.8 gives

$$
-\frac{d S_{i}}{\mathrm{dT}}=\frac{\mathrm{Aa}^{\mathrm{n}-1}}{\beta} \exp \left(-\frac{\mathrm{E}_{\mathrm{a}}}{\mathrm{RT}}\right) \mathrm{S}_{\mathrm{i}}^{\mathrm{n}}
$$

Because

$$
S_{i}=\int_{T_{i}}^{T_{f}} h_{i} d T
$$

where $h_{i}$ is the height of the curve at any specified temperature $T_{i}$,

$$
h_{i}=-\frac{d s_{i}}{d T}
$$

Combining Equations 3.9 and 3.11 provides

$$
h_{i}=\frac{\mathrm{Aa}^{\mathrm{n}-1}}{\beta} \exp \left(-\frac{\mathrm{E}_{\mathrm{a}}}{\mathrm{RT}}\right) \mathrm{S}_{\mathrm{i}}^{\mathrm{n}}
$$

At the highest point of the peak,

$$
\frac{d h_{i}}{d T}=\left[\frac{\mathrm{Aa}^{\mathrm{n}-1}}{\beta} \exp \left(-\frac{\mathrm{E}_{\mathrm{a}}}{\mathrm{RT}}\right)\right]\left(\frac{\mathrm{E}_{\mathrm{a}}}{\mathrm{RT}^{2}} \mathrm{~S}_{\mathrm{i}}^{\mathrm{n}}+\mathrm{nS}_{\mathrm{i}}^{\mathrm{n}-1} \frac{d S_{i}}{d T}\right)=0
$$

Thus,

$$
\frac{\mathrm{E}_{\mathrm{a}}}{\mathrm{RT}_{\mathrm{p}}{ }^{2}} \mathrm{~S}_{\mathrm{p}}+\mathrm{n}\left(\frac{d S_{i}}{d T}\right)_{\mathrm{T}=\mathrm{T}_{\mathrm{P}}}=0
$$

Where $T_{p}$ is temperature at the highest point of the peak and $S_{p}$ the area of the peak from $T_{p}$ to $T_{f}$. 
Introduction of Equation3.11 into Equation 3.14 produces

$$
\mathrm{n}=\frac{\mathrm{S}_{\mathrm{p}} \mathrm{E}_{\mathrm{a}}}{\mathrm{h}_{\mathrm{p}} \mathrm{RT}_{\mathrm{p}}^{2}}
$$

where $h_{p}$ is the peak height at the maximum point of the peak.

The rearrangement of Equation (3.12) provides

$$
\ln h_{i}=\ln \left(\frac{\mathrm{Aa}^{\mathrm{n}-1}}{\beta}\right)-\frac{\mathrm{E}_{\mathrm{a}}}{\mathrm{RT}}+\mathrm{nln} S_{i}
$$

The combination of Equations 3.15 and 3.16 provides

$$
\ln h_{i}=\ln \left(\frac{\mathrm{Aa}^{\mathrm{n}-1}}{\beta}\right)-\frac{\mathrm{E}_{\mathrm{a}}}{\mathrm{R}}\left(\frac{1}{\mathrm{~T}_{\mathrm{i}}}-\frac{\mathrm{S}_{\mathrm{p}} \ln S_{i}}{\mathrm{~h}_{\mathrm{p}} \mathrm{T}_{\mathrm{p}}^{2}}\right)
$$

Equation 3.17 indicates a linear relationship between $\left(\frac{1}{\mathrm{~T}_{\mathrm{i}}}-\frac{\mathrm{S}_{\mathrm{p}} \ln S_{i}}{\mathrm{~h}_{\mathrm{p}} \mathrm{T}_{\mathrm{p}}{ }^{2}}\right)$ and $\ln h_{i}$, which has $-\frac{E_{a}}{R}$ as slope and $\ln \left(\frac{\mathrm{Aa}^{\mathrm{n}-1}}{\beta}\right)$ as intersection. This equation can allow ones to calculate the kinetic parameters including $E_{a}, n$, and $A$.

According to Equation (3.9),

$$
-\frac{d S_{i}}{S_{\mathrm{i}}{ }^{\mathrm{n}}}=\frac{\mathrm{Aa}^{\mathrm{n}-1}}{\beta} \exp \left(-\frac{\mathrm{E}_{\mathrm{a}}}{\mathrm{RT}}\right) \mathrm{dT}
$$

Integration of Equation3.18 gives

$$
\int_{S_{T_{0}}}^{S}-\mathrm{S}^{-\mathrm{n}} \mathrm{dS}=\int_{T_{0}}^{T} \frac{\mathrm{Aa}^{\mathrm{n}-1}}{\beta} \exp \left(-\frac{\mathrm{E}_{\mathrm{a}}}{\mathrm{RT}}\right) \mathrm{dT}
$$

Thus,

$$
\mathrm{S}^{1-\mathrm{n}}=S_{T_{0}}{ }^{1-\mathrm{n}}-(1-\mathrm{n}) \int_{T_{0}}^{T} \frac{\mathrm{Aa}^{\mathrm{n}-1}}{\beta} \exp \left(-\frac{\mathrm{E}_{\mathrm{a}}}{\mathrm{RT}}\right) \mathrm{dT}
$$


Rearrangement of Equation 3.20 gives

$$
\ln S=\frac{1}{1-\mathrm{n}} \ln \left[S_{T_{0}}{ }^{1-\mathrm{n}}-(1-\mathrm{n}) \int_{T_{0}}^{T} \frac{\mathrm{Aa}^{\mathrm{n}-1}}{\beta} \exp \left(-\frac{\mathrm{E}_{\mathrm{a}}}{\mathrm{RT}}\right) \mathrm{dT}\right]
$$

Equations 3.17 and 3.21 are combined as

$$
\begin{array}{r}
l n h_{i}= \\
\ln \left(\frac{\mathrm{Aa}^{\mathrm{n}-1}}{\beta}\right)-\frac{\mathrm{E}_{\mathrm{a}}}{\mathrm{R}}\left\{\frac{1}{\mathrm{~T}_{\mathrm{i}}}-\frac{\mathrm{S}_{\mathrm{p}}}{(1-\mathrm{n}) \mathrm{h}_{\mathrm{p}} \mathrm{T}_{\mathrm{p}}{ }^{2}} \ln \left[S_{T_{0}}^{1-\mathrm{n}}-(1-\mathrm{n}) \int_{T_{0}}^{\mathrm{T}_{\mathrm{i}}} \frac{\mathrm{Aa}^{\mathrm{n}-1}}{\beta} \exp \left(-\frac{\mathrm{E}_{\mathrm{a}}}{\mathrm{RT}_{\mathrm{i}}}\right) \mathrm{dT} \mathrm{T}_{\mathrm{i}}\right]\right\}
\end{array}
$$

According to Equation3.22 with obtained $E_{a}, n$, and $A$, one can draw the entire peak.

\subsection{Results and discussion}

The decomposition of $\mathrm{Li}_{2} \mathrm{NH}$ was evaluated by TPD technique. As shown in Figure 3.2 , one can see that $\mathrm{Li}_{2} \mathrm{NH}$ started to decompose at $550{ }^{\circ} \mathrm{C}$ and finished at $800{ }^{\circ} \mathrm{C}$. Because the TPD-TCD provides only total signals of all gases due to their different thermal conductivities from the carrier gas (Argon), the composition of the product gases during the TPD process was analyzed by a gas chromatography (GC) equipped with TCD detector and a Porapak Q column for each $2 \mathrm{~min}$. One can see from Table 3.1 that the peaks consisted of $\mathrm{H}_{2}$ and $\mathrm{N}_{2}$ with almost 1:1 molar ratio in the entire temperature range of the two peaks. Although $\mathrm{Li}$ is too reactive to be detected by XRD before it transferred into $\mathrm{Li}_{2} \mathrm{O}$ and $\mathrm{LiOH}$ during its relocation from the reactor to the XRD instrument, we did see shiny matter attached to the inner wall 
of the quartz tube reactor after $\mathrm{LiNH}_{2}$ decomposition at $850{ }^{\circ} \mathrm{C}$, indicating the formation of $\mathrm{Li}$. Therefore, the complete decomposition of $\mathrm{Li}_{2} \mathrm{NH}$ produced $\mathrm{Li}, \mathrm{H}_{2}$, and $\mathrm{N}_{2}$ as follows:

$$
2 \mathrm{Li}_{2} \mathrm{NH}=4 \mathrm{Li}+\mathrm{H}_{2}+\mathrm{N}_{2} \quad \Delta \mathrm{H}=444 \mathrm{~kJ} / \mathrm{mol} \mathrm{H}_{2}
$$



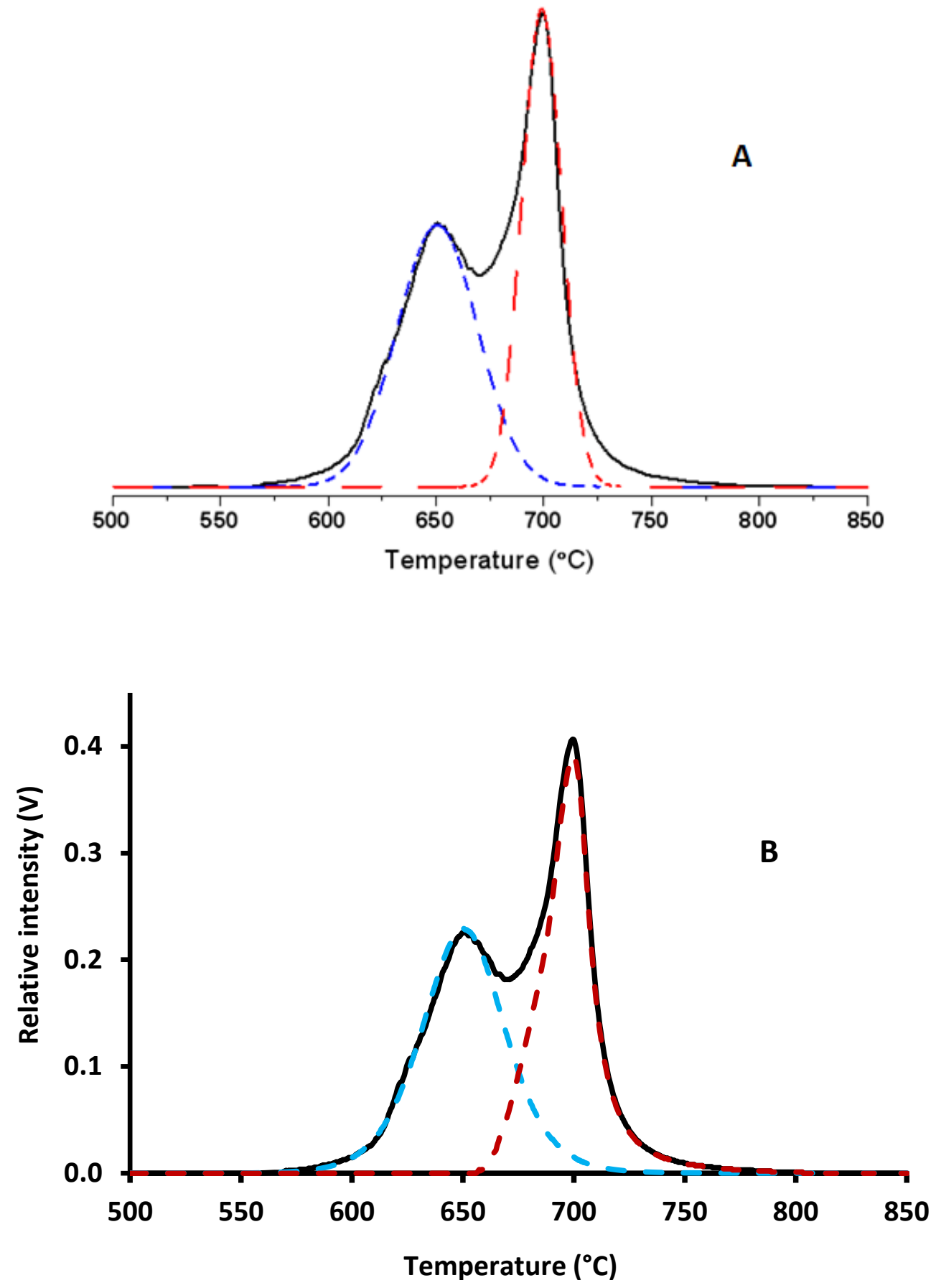

Figure 3.2 TPD-TCD profile of $\mathrm{Li}_{2} \mathrm{NH}$. The two peaks are resolved by (A) Gaussian equation fitting and (B) kinetic calculation. 
Table 3.1 Molar fraction of $\mathrm{H}_{2}$ and $\mathrm{N}_{2}$ produced in the decomposition of $\mathrm{Li}_{2} \mathrm{NH}$ at different temperatures.

\begin{tabular}{ccc}
\hline $\mathrm{T}\left({ }^{\circ} \mathrm{C}\right)$ & $\mathrm{H}_{2}(\mathrm{~mol} \%)$ & $\mathrm{N}_{2}(\mathrm{~mol} \%)$ \\
\hline 600 & 35.1 & 64.9 \\
610 & 39.4 & 60.6 \\
620 & 48.4 & 51.6 \\
630 & 47.4 & 52.6 \\
640 & 48.1 & 51.9 \\
650 & 49.5 & 50.5 \\
660 & 48.5 & 51.5 \\
670 & 46.2 & 53.8 \\
680 & 46.2 & 53.8 \\
690 & 41.2 & 58.8 \\
700 & 50.8 & 49.2 \\
710 & 56.1 & 43.9 \\
\hline
\end{tabular}

However, as shown in Figure 3.2, the decomposition of $\mathrm{Li}_{2} \mathrm{NH}$ is not a single step, because there were two TPD peaks (one at $650{ }^{\circ} \mathrm{C}$ and the other at $700{ }^{\circ} \mathrm{C}$ ) between 550 and $800{ }^{\circ} \mathrm{C}$. This means that the decomposition contains two steps. In other words, an intermediate species $\mathrm{Li}_{\mathrm{x}} \mathrm{NH}_{\mathrm{y}}$ was formed as follows:

$$
\begin{aligned}
& \frac{x}{2} L i_{2} N H=L i_{x} N H_{y}+\frac{x-2}{4} N_{2}+\frac{x-2 y}{4} H_{2} \\
& L i_{x} N H_{y}=x L i+\frac{1}{2} N_{2}+\frac{y}{2} H_{2}
\end{aligned}
$$

Because the molar ratio of $\mathrm{H}_{2}$ to $\mathrm{N}_{2}$ is equal to 1 (Table 3.1), one can know from equation 3.25 that $y$ should be 1 . The ratio of $\left(\frac{x-2}{4}+\frac{x-2 y}{4}\right)$ to $\left(\frac{1}{2}+\frac{y}{2}\right)$ equals 
to the ratio of the areas of peak 1 (corresponding to reaction 3.24) to peak 2 (corresponding to reaction 3.25). The overlapped peaks in Figure 3.2 were resolved by Gaussian function fitting, revealing that the areas of the two peaks are the same. This means that the value of $\mathrm{x}$ is 4 . Therefore, the intermediate species in the decomposition of $\mathrm{Li}_{2} \mathrm{NH}$ is $\mathrm{Li}_{4} \mathrm{NH}$.

The kinetics of the first step of the decomposition of $\mathrm{Li}_{2} \mathrm{NH}$ (Reaction 3.24) was evaluated from Figure 3.2. Because Gaussian fitting showed that the two peaks of $\mathrm{Li}_{2} \mathrm{NH}$ TPD (Figure 3.2A) have equal areas, the area $\left(\mathrm{S}_{\mathrm{t} 1}\right)$ of the first peak should be the half of the total area of the two peaks. Furthermore, one can make an approximation that the part of the first peak before the highest point has a negligible overlapping with the second peak. Therefore, the data, which are listed in Table 3.2, were obtained for temperatures not larger than $T_{p 1}$ (temperature at the highest point of the first peak). From Table 3.2, one can obtain a linear relationship between $\frac{1}{T_{i}}-\frac{S_{\mathrm{p}} l n S_{i}}{\mathrm{~h}_{\mathrm{p}} \mathrm{T}_{\mathrm{p}}{ }^{2}}$ and $\operatorname{lnh}_{\mathrm{i}}$, which is shown in Figure 3.3. From the slope (-64180) and intersection (64.86) of the line, one can obtain activation energy $\left(E_{a}\right)$ of $533.6 \mathrm{~kJ} / \mathrm{mol}$, decomposition order (n) of 1.84, and pre-exponential factor (A) of $1.34 \times 10^{29}$. This indicates that the decomposition of $\mathrm{Li}_{2} \mathrm{NH}$ to $\mathrm{Li}_{4} \mathrm{NH}$ is almost the second-order reaction. 
Table 3.2 Data obtained from the first peak of the composition of $\mathrm{Li}_{2} \mathrm{NH}$.

\begin{tabular}{cccccc}
\hline $\mathrm{T}_{\mathrm{p} 1}\left({ }^{\circ} \mathrm{C}\right)$ & $\mathrm{h}_{\mathrm{p} 1}(\mathrm{~V})$ & $\mathrm{S}_{\mathrm{p} 1}(\mathrm{VK})$ & $\mathrm{S}_{\mathrm{t} 1}(\mathrm{VK})$ & $\mathrm{a}(\mathrm{mg} / \mathrm{VK})$ & $\beta\left({ }^{\circ} \mathrm{C} / \mathrm{min}\right)$ \\
\hline 650.4 & 0.23 & 5.54 & 11.21 & 0.49 & 5 \\
\hline \multirow{2}{*}{$\mathrm{T}_{\mathrm{i}}\left({ }^{\circ} \mathrm{C}\right)$} & $\ln \mathrm{S}_{\mathrm{i}}$ & $\frac{1}{\mathrm{~T}_{\mathrm{i}}}-\frac{\mathrm{S}_{\mathrm{p}} \ln S_{i}}{\mathrm{~h}_{\mathrm{p}} \mathrm{T}_{\mathrm{p}}{ }^{2}}$ & $1 \operatorname{lnh}_{\mathrm{i}}$ \\
\hline 600.3 & 2.40 & 0.001076 & -4.22 \\
610.1 & 2.38 & 0.001064 & -3.52 \\
620.2 & 2.33 & 0.001053 & -2.57 \\
630.3 & 2.22 & 0.001043 & -2.09 \\
640.1 & 2.05 & 0.001036 & -1.70 \\
650.4 & 1.71 & 0.001034 & -1.48 \\
\hline
\end{tabular}

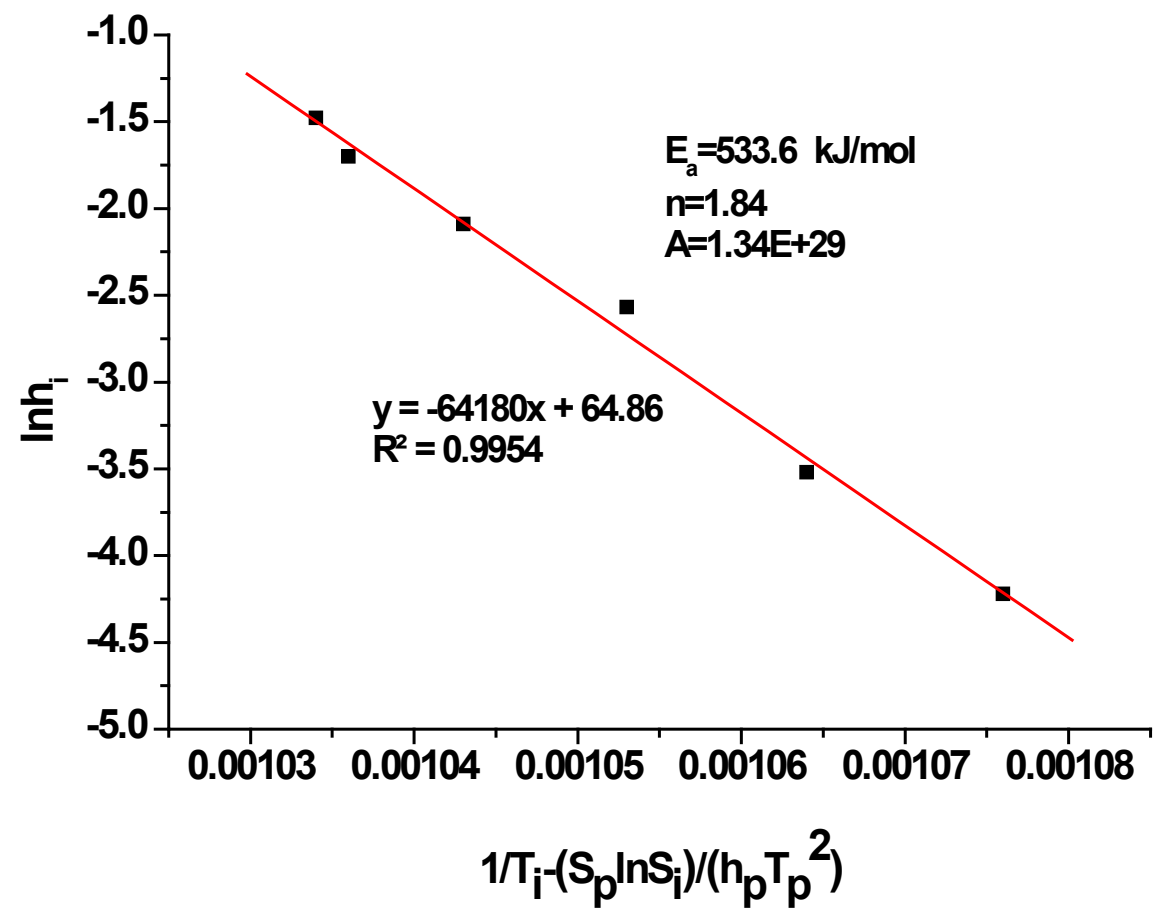

Figure 3.3 $\operatorname{lnh} \mathrm{i}_{\mathrm{i}}$ VS. $\left(\frac{\mathbf{1}}{\mathbf{T}_{\mathbf{i}}}-\frac{\mathbf{S}_{\mathbf{p}} l n s_{\boldsymbol{i}}}{\mathbf{h}_{\mathbf{p}} \mathrm{T}_{\mathbf{p}}{ }^{2}}\right)$ for the first peak of the composition of $\mathrm{Li}_{2} \mathrm{NH}$. 
According to Equation3.22 with obtained $\mathrm{E}_{\mathrm{a}}$, $\mathrm{n}$, and $\mathrm{A}$, one can draw the entire first peak (corresponding to reaction 3.24) as the dashed blue peak (Figure 3.2B). The area of the first peak generated by Equation 3.22 is exactly equal to the half of the area of the two peaks, which is consistent with the peak separation from the Gaussian function fitting.

The subtraction of the first peak height (calculated with Equation 3.22) from the total height of the overlapped two peaks can generate the separated second peak (Figure 3.2B), from which the data for the second peak were obtained (Table 3.3). As shown in Figure 3.4, one can see a linear relationship between $\frac{1}{\mathrm{~T}_{\mathrm{i}}}-\frac{\mathrm{S}_{\mathrm{p}} \ln S_{i}}{\mathrm{~h}_{\mathrm{p}} \mathrm{T}_{\mathrm{p}}{ }^{2}}$ and $\operatorname{lnh}_{\mathrm{i}}$. This provides the kinetic parameters for reaction 3.25, including activation energy $\left(E_{a}\right)$ of $754.2 \mathrm{~kJ} / \mathrm{mol}$, decomposition order (n) of 1.18, and pre-exponential factor (A) of $1.05 \times 10^{40}$. Therefore, the decomposition of $\mathrm{Li}_{4} \mathrm{NH}$ to $\mathrm{Li}, \mathrm{H}_{2}$, and $\mathrm{N}_{2}$ is almost the first-order reaction. 
Table 3.3 Data obtained from the second peak of the composition of $\mathrm{Li}_{2} \mathrm{NH}$.

\begin{tabular}{cccccc}
\hline $\mathrm{T}_{\mathrm{p} 2}\left({ }^{\circ} \mathrm{C}\right)$ & $\mathrm{h}_{\mathrm{p} 2}(\mathrm{~V})$ & $\mathrm{S}_{\mathrm{p} 2}(\mathrm{VK})$ & $\mathrm{S}_{\mathrm{t} 2}(\mathrm{VK})$ & $\mathrm{a}(\mathrm{mg} / \mathrm{VK})$ & $\beta\left({ }^{\circ} \mathrm{C} / \mathrm{min}\right)$ \\
\hline 699.8 & 0.39 & 4.82 & 11.21 & 0.49 & 5 \\
\hline $\mathrm{T}_{\mathrm{i}}\left({ }^{\circ} \mathrm{C}\right)$ & $\ln \mathrm{S}_{\mathrm{i}}$ & & $\frac{1}{\mathrm{~T}_{\mathrm{i}}}-\frac{\mathrm{S}_{\mathrm{p}} \ln S_{i}}{\mathrm{~h}_{\mathrm{p}} \mathrm{T}_{\mathrm{p}}{ }^{2}}$ & $1 \mathrm{lnh}_{\mathrm{i}}$ \\
\hline 667.1 & 2.41 & 0.001032 & -3.31 \\
672.4 & 2.38 & 0.001027 & -2.64 \\
677.3 & 2.34 & 0.001022 & -2.18 \\
682.5 & 2.27 & 0.001017 & -1.82 \\
687.4 & 2.17 & 0.001013 & -1.55 \\
692.6 & 2.00 & 0.001009 & -1.20 \\
697.2 & 1.76 & 0.001008 & -0.98 \\
699.8 & 1.57 & 0.001007 & -0.94 \\
\hline
\end{tabular}

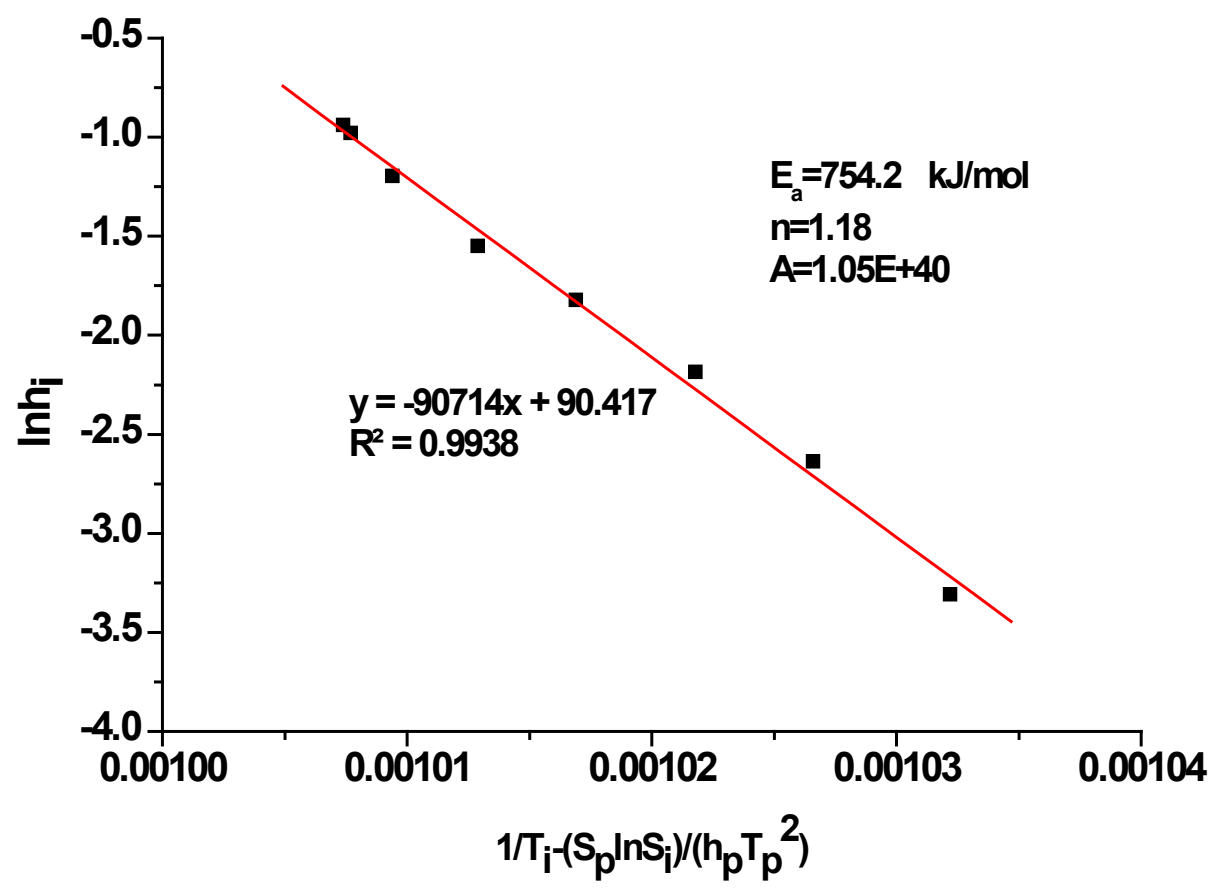

Figure 3.4 $\operatorname{lnh}_{\mathrm{i}}$ vs. $\left(\frac{1}{\mathrm{~T}_{\mathbf{i}}}-\frac{\mathrm{S}_{\mathbf{p}} I n s_{i}}{\mathbf{h}_{\mathbf{p}} \mathrm{T}_{\mathbf{p}}{ }^{2}}\right)$ for the second peak of the composition of $\mathrm{Li}_{2} \mathrm{NH}$. 
Furthermore, the solid products from the $\mathrm{Li}_{2} \mathrm{NH}$ TPD process were characterized by XRD. As shown in Figure 3.5, one can see cubic $\mathrm{Li}_{2} \mathrm{NH}$ peaks at $550{ }^{\circ} \mathrm{C}$ before the decomposition started. With increasing temperature, there is an obvious peak-shifting in the XRD pattern of $\mathrm{Li}_{2} \mathrm{NH}$ (Figure 3.5), corresponding to the change of cubic lattice parameter. As discussed above, the decomposition of $\mathrm{Li}_{2} \mathrm{NH}$ produced $\mathrm{Li}_{4} \mathrm{NH}$ in the first step (reaction 3.24). The XRD patterns for all samples, which were obtained in the temperature range where two TPD peaks occurred, indicated that there is only a cubic phase. In other words, $\mathrm{Li}_{4} \mathrm{NH}$ should possess a similar cubic crystal structure as $\mathrm{Li}_{2} \mathrm{NH}$. The lattice parameters of the solid products obtained at different temperatures were listed in Table 3.4. It can be seen that the lattice parameter decreases with increasing decomposition of $\mathrm{Li}_{2} \mathrm{NH}$. Because the first peak is associated with the decomposition of $\mathrm{Li}_{2} \mathrm{NH}$ to $\mathrm{Li}_{4} \mathrm{NH}$, the samples, which were obtained in the temperature range of the first peak, should contain both $\mathrm{Li}_{2} \mathrm{NH}$ and $\mathrm{Li}_{4} \mathrm{NH}$. The observation of only one phase in their XRD patterns indicates that $\mathrm{Li}_{2} \mathrm{NH}$ and $\mathrm{Li}_{4} \mathrm{NH}$ form a solid solution. Furthermore, the lattice parameters of those samples were correlated with molar ratio of $\mathrm{Li}_{2} \mathrm{NH}$ to $\mathrm{Li}_{4} \mathrm{NH}$ when the $\mathrm{Li}_{2} \mathrm{NH}$ content is greater than or equal to $13 \mathrm{~mol} \%$, leading to a linear equation (Figure 3.6):

$$
\mathrm{a}=0.0027 \mathrm{x}+0.5033
$$

Where a is lattice parameter (with unit of $\mathrm{nm}$ ) and $\mathrm{x}$ is molar fraction of $\mathrm{Li}_{2} \mathrm{NH}$ in $\mathrm{Li}_{2} \mathrm{NH} / \mathrm{Li}_{4} \mathrm{NH}$ solid solution. This indicates that the solid solution follows Vegard's law. Furthermore, the above equation can be used to predict the lattice parameter of 
$\mathrm{Li}_{4} \mathrm{NH}$, which is $0.5033 \mathrm{~nm}$. It was reported that $\mathrm{Li}_{4} \mathrm{NH}$ can be formed from the reaction of $\mathrm{LiNH}_{2}$ and $\mathrm{Li}_{3} \mathrm{~N}$ in liquid $\mathrm{Li}$ [116] or the reaction of $\mathrm{Li}_{3} \mathrm{~N}$ and $\mathrm{LiH}$ [117]. The $\mathrm{Li}_{4} \mathrm{NH}$ obtained from those reactions occupied a tetragonal structure $[116,117]$. Furthermore, the DFT calculations showed that the tetragonal structure is stable [105]. In contrast, the $\mathrm{Li}_{2} \mathrm{NH}$ decomposition produced cubic $\mathrm{Li}_{4} \mathrm{NH}$. This indicates that cubic $\mathrm{Li}_{2} \mathrm{NH}$ induced the formation of cubic $\mathrm{Li}_{4} \mathrm{NH}$ and stabilize it via the formation of solid solution. However, when the content of cubic $\mathrm{Li}_{2} \mathrm{NH}$ becomes too small to stabilize the relatively instable cubic structure of $\mathrm{Li}_{4} \mathrm{NH}$, the cubic $\mathrm{Li}_{4} \mathrm{NH}$ might tend to more stable tetragonal state. This can explain why the lattice parameter of solid solution decreased very much with increasing $\mathrm{Li}_{4} \mathrm{NH}$ content when the content of $\mathrm{Li}_{2} \mathrm{NH}$ is less than $13 \%$ (Figure 3.6). 


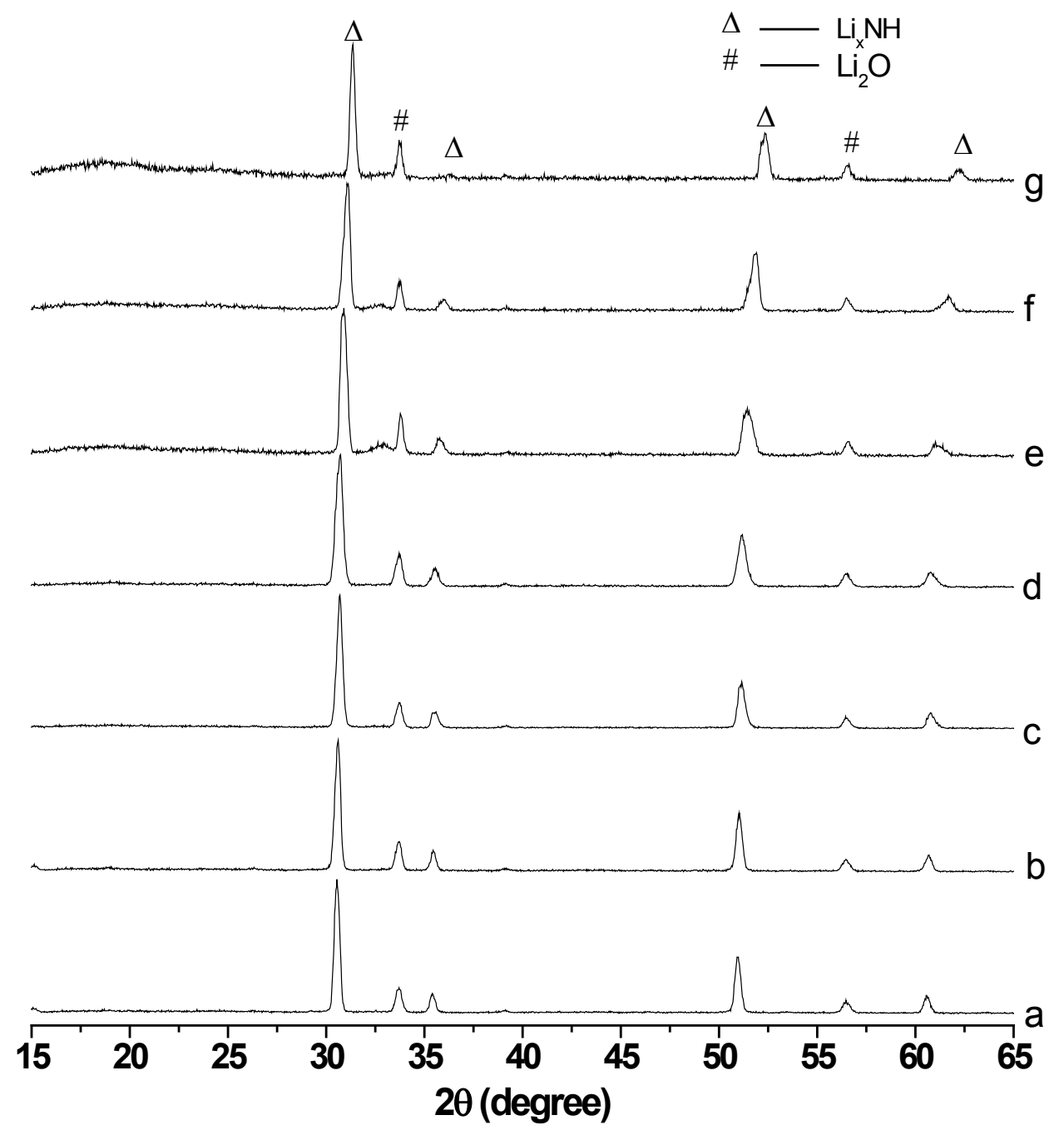

Figure 3.5 XRD patterns of the solid products from the TPD process of $\mathrm{Li}_{2} \mathrm{NH}$ that were stopped at (a) $550{ }^{\circ} \mathrm{C}$, (b) $607{ }^{\circ} \mathrm{C}$, (c) $650{ }^{\circ} \mathrm{C}$, (d) $680{ }^{\circ} \mathrm{C}$, (e) $690{ }^{\circ} \mathrm{C}$, (f) $700{ }^{\circ} \mathrm{C}$, and (g) $710^{\circ} \mathrm{C}$. 
Table 3.4 Lattice parameters of the solid products from the TPD process of $\mathrm{Li}_{2} \mathrm{NH}$.

\begin{tabular}{ccc}
\hline \multicolumn{3}{c}{$\begin{array}{c}\text { Molar fraction of } \\
\mathrm{Li}_{2} \mathrm{NH} \text { in } \\
\mathrm{Li}_{2} \mathrm{NH}+\mathrm{Li}{ }_{4} \mathrm{NH} \\
\text { solid solution }\end{array}$} \\
\hline 550 & 1.00 & $\mathrm{a}(\mathrm{nm})$ \\
607 & 0.99 & 0.5067 \\
650 & 0.66 & 0.5056 \\
680 & 0.13 & 0.5044 \\
690 & 0.06 & 0.5013 \\
700 & 0.03 & 0.4980 \\
710 & 0.02 & 0.4939 \\
\hline
\end{tabular}

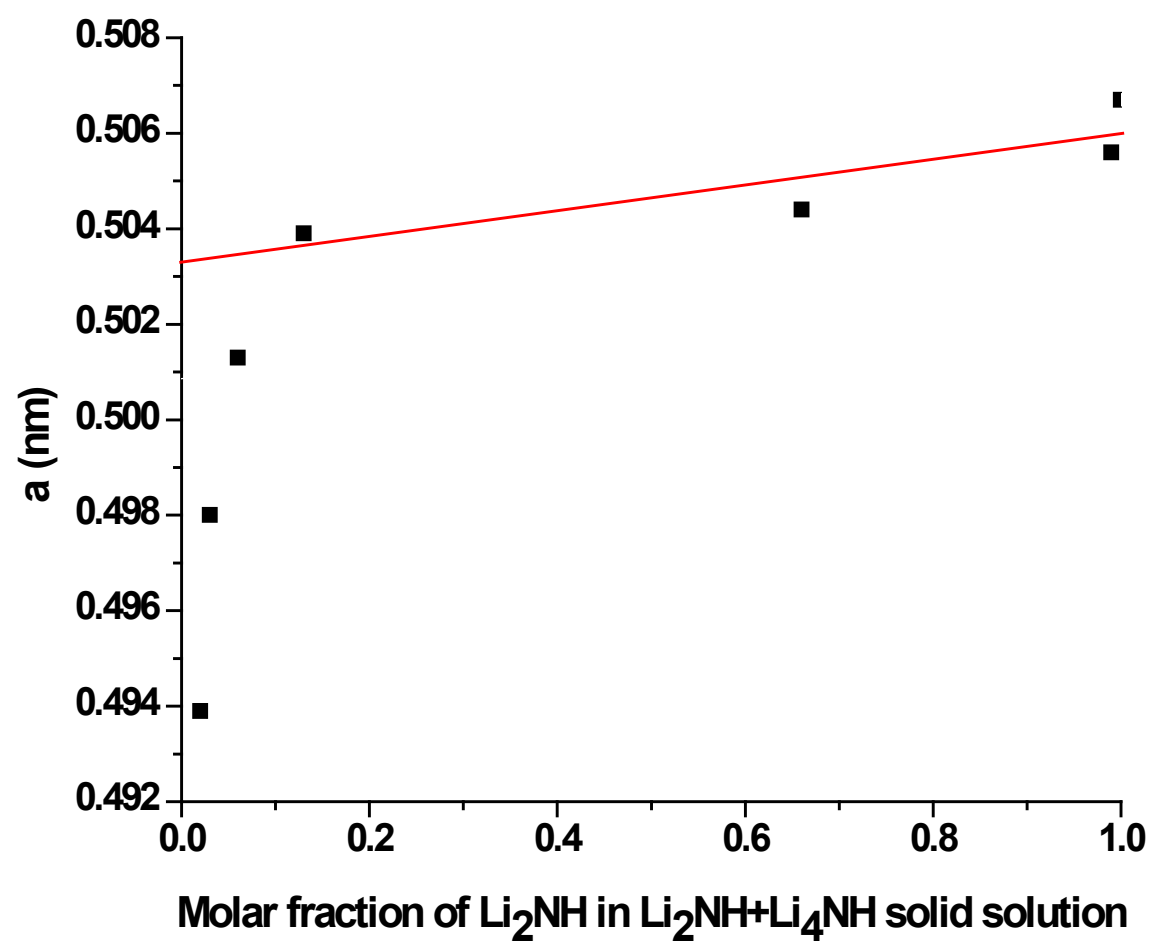

Figure 3.6 Lattice parameters of the solid products from the TPD process of $\mathrm{Li}_{2} \mathrm{NH}$ vs. the molar fraction of $\mathrm{Li}_{2} \mathrm{NH}$ in $\mathrm{Li}_{2} \mathrm{NH} / \mathrm{Li}_{4} \mathrm{NH}$ solid solution. 
Thus, $\mathrm{Li}_{2} \mathrm{NH}$ is decomposed into $\mathrm{Li}, \mathrm{H}_{2}$ and $\mathrm{N}_{2}$ without $\mathrm{Li}_{3} \mathrm{~N}$ formation. This can further be supported by the XRD measurement, in which no $\mathrm{Li}_{3} \mathrm{~N}$ in the samples of $\mathrm{LiNH}_{2}$ decomposed at 650 and at $690{ }^{\circ} \mathrm{C}$ was detected (Figure 3.5). Furthermore, $\mathrm{Li}_{3} \mathrm{~N}$ sample was subjected to TPD measurements. As shown in Figure 3.7, one can see that $\mathrm{Li}_{3} \mathrm{~N}$ started to decompose at $470{ }^{\circ} \mathrm{C}$, which is lower than that $\left(550{ }^{\circ} \mathrm{C}\right)$ of $\mathrm{Li}_{2} \mathrm{NH}$. This indicates that $\mathrm{Li}_{2} \mathrm{NH}$ is more stable than $\mathrm{Li}_{3} \mathrm{~N}$, which can explain why no $\mathrm{Li}_{3} \mathrm{~N}$ can be formed in the decomposition of $\mathrm{Li}_{2} \mathrm{NH}$.

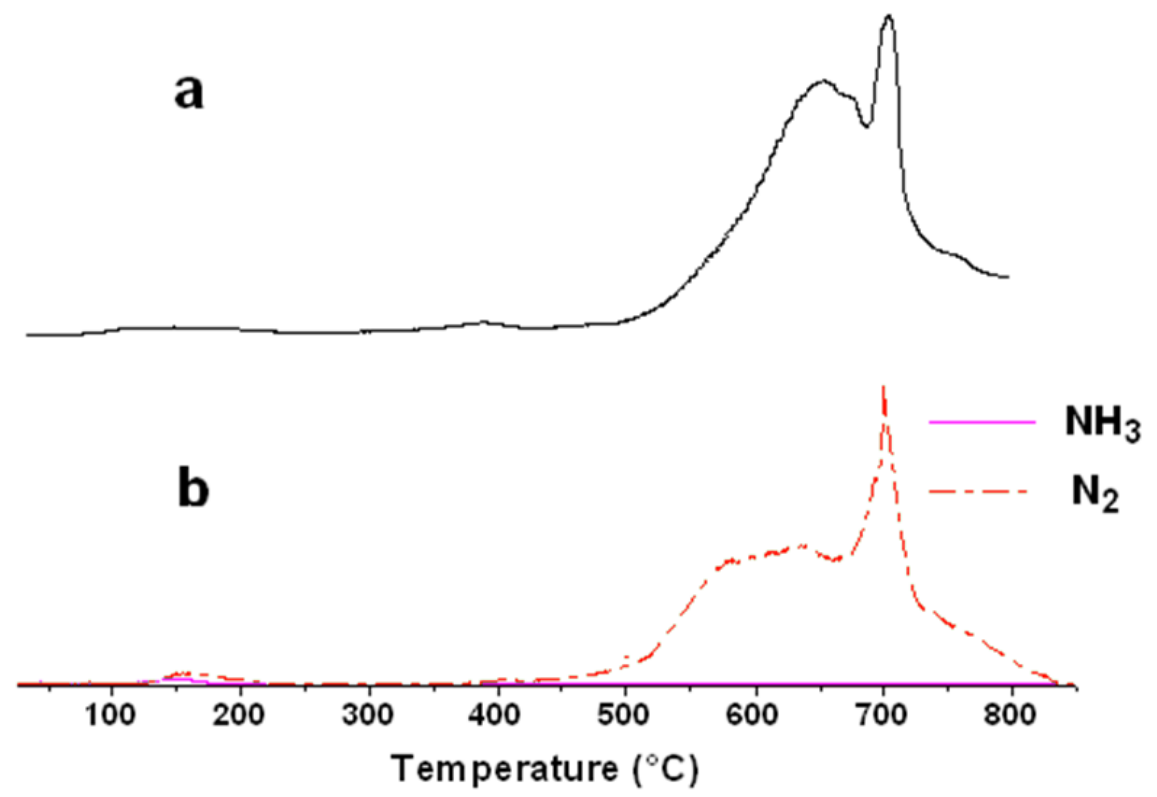

Figure 3.7 (a) TPD-TCD profile and (b) TPD-MS profile of $\mathrm{Li}_{3} \mathrm{~N}$. 


\subsection{Conclusion}

$\mathrm{Li}_{2} \mathrm{NH}$ is decomposed into $\mathrm{Li}, \mathrm{H}_{2}$ and $\mathrm{N}_{2}$ without formation of $\mathrm{Li}_{3} \mathrm{~N}$ in the temperature range of 550 to $800{ }^{\circ} \mathrm{C}$. The decomposition of $\mathrm{Li}_{2} \mathrm{NH}$ produced $\mathrm{Li}, \mathrm{H}_{2}$ and $\mathrm{N}_{2}$ via two steps: (1) $\mathrm{Li}_{2} \mathrm{NH}$ into $\mathrm{Li}_{4} \mathrm{NH}, \mathrm{N}_{2}$, and $\mathrm{H}_{2}$ and (2) $\mathrm{Li}_{4} \mathrm{NH}$ into $\mathrm{Li}, \mathrm{N}_{2}$, and $\mathrm{H}_{2}$. The first step is the seond-order reaction with activation energy of 533.6 $\mathrm{kJ} / \mathrm{mol}$, whereas the second step is the first-order reaction with activation energy of $754.2 \mathrm{~kJ} / \mathrm{mol}$. $\mathrm{Li}_{4} \mathrm{NH}$, which was generated in the decomposition of $\mathrm{Li}_{2} \mathrm{NH}$, formed a solid solution with $\mathrm{Li}_{2} \mathrm{NH}$. In the solid solution, $\mathrm{Li}_{4} \mathrm{NH}$ possesses a similar cubic structure as $\mathrm{Li}_{2} \mathrm{NH}$. The lattice parameter of cubic $\mathrm{Li}_{4} \mathrm{NH}$ is $0.5033 \mathrm{~nm}$.

Our hypothesis that a new compound $\mathrm{Li}_{4} \mathrm{NH}$ may form during the decomposition of $\mathrm{Li}_{2} \mathrm{NH}$ is true. 


\title{
Chapter 4 Effect of anion promoter $\mathrm{Cl}^{-}$on the
}

\author{
decomposition of lithium amide *
}

\subsection{Introduction}

Dehydrogenation of $\mathrm{Li}_{2} \mathrm{NH} / \mathrm{LiH}$ back to $\mathrm{Li}_{3} \mathrm{~N}$ (the reverse direction of Reaction 2.1) is very difficult, the attention was focused on the reaction 4.2 as a reversible hydrogen storage process, which provides $6.8 \mathrm{wt} \%$ hydrogen capacity [52]. The dehydrogenation mechanism of $\mathrm{LiNH}_{2} / \mathrm{LiH}$ consists of two steps with $\mathrm{NH}_{3}$ intermediate species (Equations 2.3 and 2.4) [34]. The reaction between $\mathrm{NH}_{3}$ and $\mathrm{LiH}$ (Equation 2.4) was exothermic and ultra fast [34]. Therefore, the decomposition of $\mathrm{LiNH}_{2}$ (Equation 2.3) is the rate-determining step, which requires a high temperature.

The DOE target for hydrogen storage dehydrogenation temperature is between $-40{ }^{\circ} \mathrm{C}$ and $85{ }^{\circ} \mathrm{C}$ [6]. However, in the Li-N-H system, the $\mathrm{H}_{2}$ releasing temperature is nearly $200{ }^{\circ} \mathrm{C}$ [33], which is too high to be used for on-board hydrogen storage.

\footnotetext{
*The material contained in this chapter was previously published in the journal Industrial and Engineering Chemistry Research 2011, 50 (13), 8058-8064 by Junqing Zhang and Yun Hang Hu. See Appendix for documentation of permission to republish this material.
} 
Current efforts to decrease the dehydrogenation temperature of Li-N-H system are being focused on the introduction of metal or cation promoters, including $\mathrm{Mg}, \mathrm{Ni}, \mathrm{Fe}$, $\mathrm{Co}, \mathrm{Mn}, \mathrm{VCl}_{3}$, and $\mathrm{TiCl}_{3}$ [47-49]. Figure 4.1 shows the thermal desorption profiles of $\mathrm{H}_{2}$ and $\mathrm{NH}_{3}$ of the ball milled mixtures of $\mathrm{LiNH}_{2}$ and $\mathrm{LiH}$ with 1:1 molar ratio, in which added with a small amount ( $1 \mathrm{~mol} \%)$ of $\mathrm{Ni}, \mathrm{Fe}$ and $\mathrm{Co}$ nanometer sized metals, $\mathrm{VCl}_{3}$ and $\mathrm{TiCl}_{3}$ before milling. The gases were monitored by mass spectrometry with the sample heating rate $5{ }^{\circ} \mathrm{C} / \min$ [40]. It shows that all the additives have effects on decreasing the hydrogen releasing temperature. 


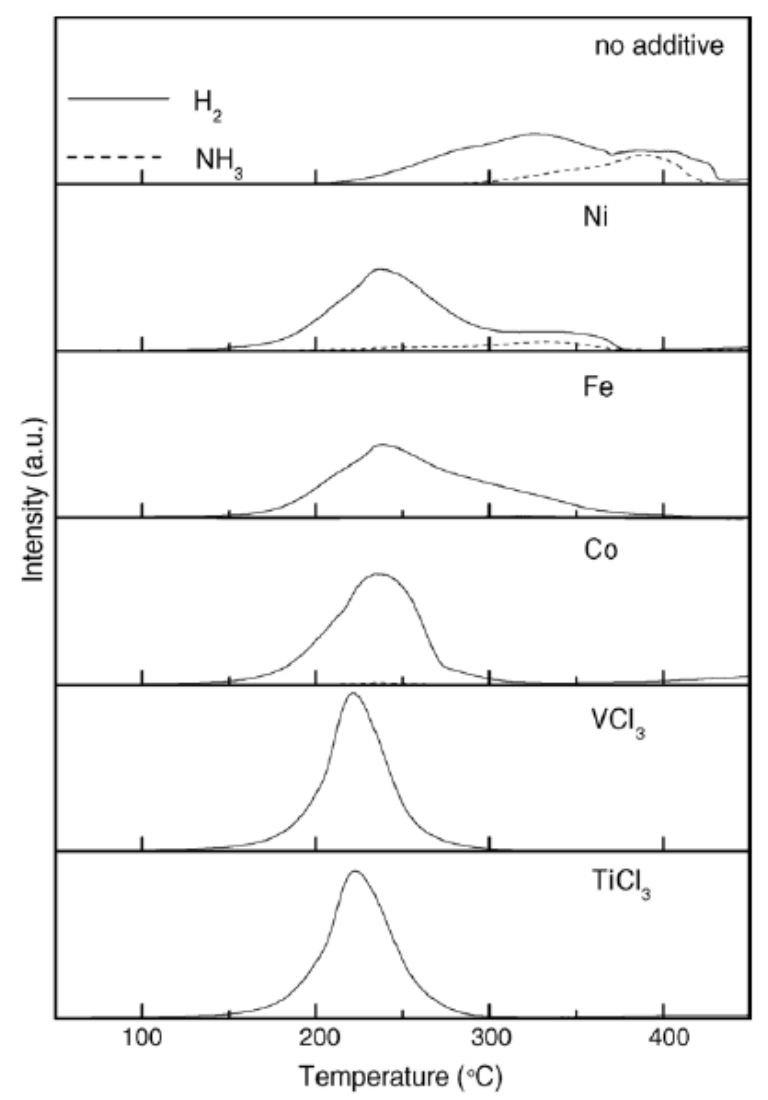

Figure 4.1 Thermal desorption profiles of $\mathrm{H}_{2}$ and $\mathrm{NH}_{3}$ of the ball milled mixtures of $\mathrm{LiNH}_{2}$ and LiH with 1:1 molar ratio, in which added with a small amount ( $\left.1 \mathrm{~mol} \%\right)$ of $\mathrm{Ni}, \mathrm{Fe}$ and $\mathrm{Co}$ nanometer sized metals, and $\mathrm{VCl}_{3}$ and $\mathrm{TiCl}_{3}$ before milling [40]. (With permission from Elsevier)

Nevertheless, effects of doping-anions on this $\mathrm{Li}-\mathrm{N}-\mathrm{H}$ hydrogen storage system have attracted little attention. One of the reasons is probably that the anion of a promoter is always accompanied with a corresponding cation. The effect of the promoter is often attributed to its cation instead of its anion.

We hypothesize that the decomposition of $\mathrm{LiNH}_{2}$ may be promoted by anion promoter. This is based on the following observation. It can be seen in Figure 4.1 
that the $\mathrm{H}_{2}$ peak shapes by adding $\mathrm{VCl}_{3}$ and $\mathrm{TiCl}_{3}$ are almost the same. Since the cations are different, the effect probably should be attributed to the anion $\left(\mathrm{Cl}^{-}\right)$. The decomposition of $\mathrm{LiNH}_{2}$ is the elementary and rate-determining reaction of the hydrogen releasing process in the $\mathrm{LiNH}_{2} / \mathrm{LiH}$ mixture. So, the decomposition of $\mathrm{LiNH}_{2}$ may be promoted by the anion $\left(\mathrm{Cl}^{-}\right)$.

As the realization of the important roles that anions play in biology, [119] catalysis [120], and the environment [121, 122] has grown; interest in anion chemistry has become more widespread. For example, the stringent environmental regulations on the sulfur content in transportation fuels force ones to use hydrotreatment catalysts with enhanced hydrogenating and acid functionalities in order to improve the removal of the most refractory sulfur compounds, substituted dibenzothiophenes, from the different petroleum fractions. Anion-modified aluminabased catalysts present these characteristics $[123,124]$. This work stimulated much interest to reveal why the doping-anion can exhibit so remarkable promoting-effect. Nevertheless, effects of doping-anions on hydrogen storage materials have attracted limited attention. One of reasons is probably that the anion of a promoter is always accompanied with a corresponding cation. The effect of the promoter is often attributed to its cation instead of its anion. However, recently, the anion promoting effects on hydrogen storage in $\mathrm{LiBH}_{4}$ and $\mathrm{MgH}_{2}$ were reported [125-128]. Furthermore, in the Li-N-H hydrogen storage system, $\mathrm{LiNH}_{2}$ doped with $\mathrm{LiBH}_{4}$ was intensively studied [129-132]. This proved the effect of $\left[\mathrm{BH}_{4}\right]^{-}$anion on hydrogen storage in Li-N-H system. 
In this work, the effect of $\mathrm{Cl}^{-}$anion on the decompositions of $\mathrm{LiNH}_{2}$ and $\mathrm{Li}_{2} \mathrm{NH}$ was examined, because $\mathrm{Cl}^{-}$anion was widely employed as a promoter to improve various catalysts. As a result, the remarkable effects of $\mathrm{Cl}^{-}$anion were found.

\subsection{Experiments}

\subsubsection{Sample preparations}

Lithium amide powder (95\%) and lithium chloride reagent (99+ \%), which had been purchased from Aldrich Chemical Co., were used without any further purification. The introduction of lithium chloride into lithium amide was carried out by mixing them with an agate mortar and pestle for $5 \mathrm{~min}$ in an argon filled glove box to protect from moisture. The molar ratio of lithium amide and lithium chloride in the mixtures varied from 9:1 to $1: 9$.

\subsubsection{Temperature-programmed decomposition}

The temperature-programmed decomposition (TPD) experiments were performed as follows: A sample $(0.01 \mathrm{~g})$ was loaded into a vertical quartz tube reactor, which was located in an electric tube furnace. The temperature of the reactor was increased to $800{ }^{\circ} \mathrm{C}$ at a rate of $5{ }^{\circ} \mathrm{C} / \mathrm{min}$. Argon $(30 \mathrm{~mL} / \mathrm{min})$ was employed as a carrier gas through the reactor to bring the gaseous products of the decomposition

of the sample into a thermal conductivity detector (TCD, Figure 2.1), generating a 
TPD-TCD profile. Furthermore, to determine all gas products except hydrogen, helium was used to carry the products from the TPD reactor into a mass spectrometer (HP 5970 series mass selective detector, Figure 2.2) instead of TCD detector, generating a TPD-MS profile.

\subsubsection{X-ray diffraction (XRD)}

A sample $(0.1 \mathrm{~g})$ was loaded into a vertical quartz tube reactor $(5-\mathrm{mm}$ diameter) located in an electric tube furnace. Argon $(30 \mathrm{~mL} / \mathrm{min})$ was introduced into the reactor at room temperature, followed by heating to a selected temperature at a rate of $5{ }^{\circ} \mathrm{C} / \mathrm{min}$ and then cooling down to room temperature. The obtained samples were subjected to XRD measurements, which were performed with a Siemens D500 X-ray diffraction instrument equipped with a $\mathrm{Cu} \mathrm{K \alpha}$ source, at $45 \mathrm{kV}$ and $35 \mathrm{~mA}$ (Figure 2.3). The scanning speed was $1 \%$ min. The mixture of $\mathrm{LiNH}_{2}$ and $\mathrm{LiCl}$ samples were covered with plastic wrap during the XRD measurements to prevent $\mathrm{LiCl}$ from absorbing the $\mathrm{H}_{2} \mathrm{O}$ in air.

\subsection{Results and discussion}

To examine the effect of anion $\left(\mathrm{Cl}^{-}\right)$on the decomposition of $\mathrm{LiNH}_{2}, \mathrm{Cl}^{-}$was doped into $\mathrm{LiNH}_{2}$ via mixing $\mathrm{LiCl}$ and $\mathrm{LiNH}_{2}$ with various mole ratios from 1:9 to 9:1 so that any new cation was not introduced. The $\mathrm{Cl}^{-}$-doped $\mathrm{LiNH}_{2}$ samples were 
subjected to TPD measurements with TCD and MS detectors. As shown in Figure 4.2, $\mathrm{LiCl}$ changed the TPD profiles of $\mathrm{LiNH}_{2}$, namely, a new $\mathrm{NH}_{3}$ peak occurred at low temperature of about $250{ }^{\circ} \mathrm{C}$ besides the original $\mathrm{NH}_{3}$ peak at $330{ }^{\circ} \mathrm{C}$. This indicates that $\mathrm{Cl}^{-}$promoted the decomposition of $\mathrm{LiNH}_{2}$ into $\mathrm{Li}_{2} \mathrm{NH}$ and $\mathrm{NH}_{3}$. This can be explained as the interaction between $\mathrm{Cl}^{-}$and $\mathrm{LiNH}_{2}$, which can weaken the bond between $\mathrm{Li}^{+}$and $\left(\mathrm{NH}_{2}\right)^{-}$. The interaction is determined by the contact between the surfaces of $\mathrm{LiCl}$ and $\mathrm{LiNH}_{2}$ particles to form an interface, which leads to the decomposition of $\mathrm{LiNH}_{2}$ a low temperature. Furthermore, $\mathrm{LiCl}$ can absorb $\mathrm{NH}_{3}$ to form a series of lithium chloride ammonia complexes $\mathrm{Li}\left(\mathrm{NH}_{3}\right)_{\mathrm{X}} \mathrm{Cl}(\mathrm{x}=4,3,2,1)$ [133]. Therefore, the temperature, at which we can detect $\mathrm{NH}_{3}$, is dependent on the stability of the complexes, which can decompose to release $\mathrm{NH}_{3}$ at temperature above $200{ }^{\circ} \mathrm{C}$ [133]. This can explain why the new $\mathrm{NH}_{3}$ was detected at temperature of about $250{ }^{\circ} \mathrm{C}$. The original $\mathrm{NH}_{3}$ at $330{ }^{\circ} \mathrm{C}$ still remained, because the $\mathrm{LiNH}_{2}$ inside the particles don't contact $\mathrm{LiCl}$. It would be noted that the peaks at about $100{ }^{\circ} \mathrm{C}$ were confirmed as a result of the reaction between $\mathrm{H}_{2} \mathrm{O}$ adsorbed on $\mathrm{LiCl}$ and $\mathrm{LiNH}_{2}$. The adsorbed $\mathrm{H}_{2} \mathrm{O}$ originated from the air due to exposing the sample to it. 

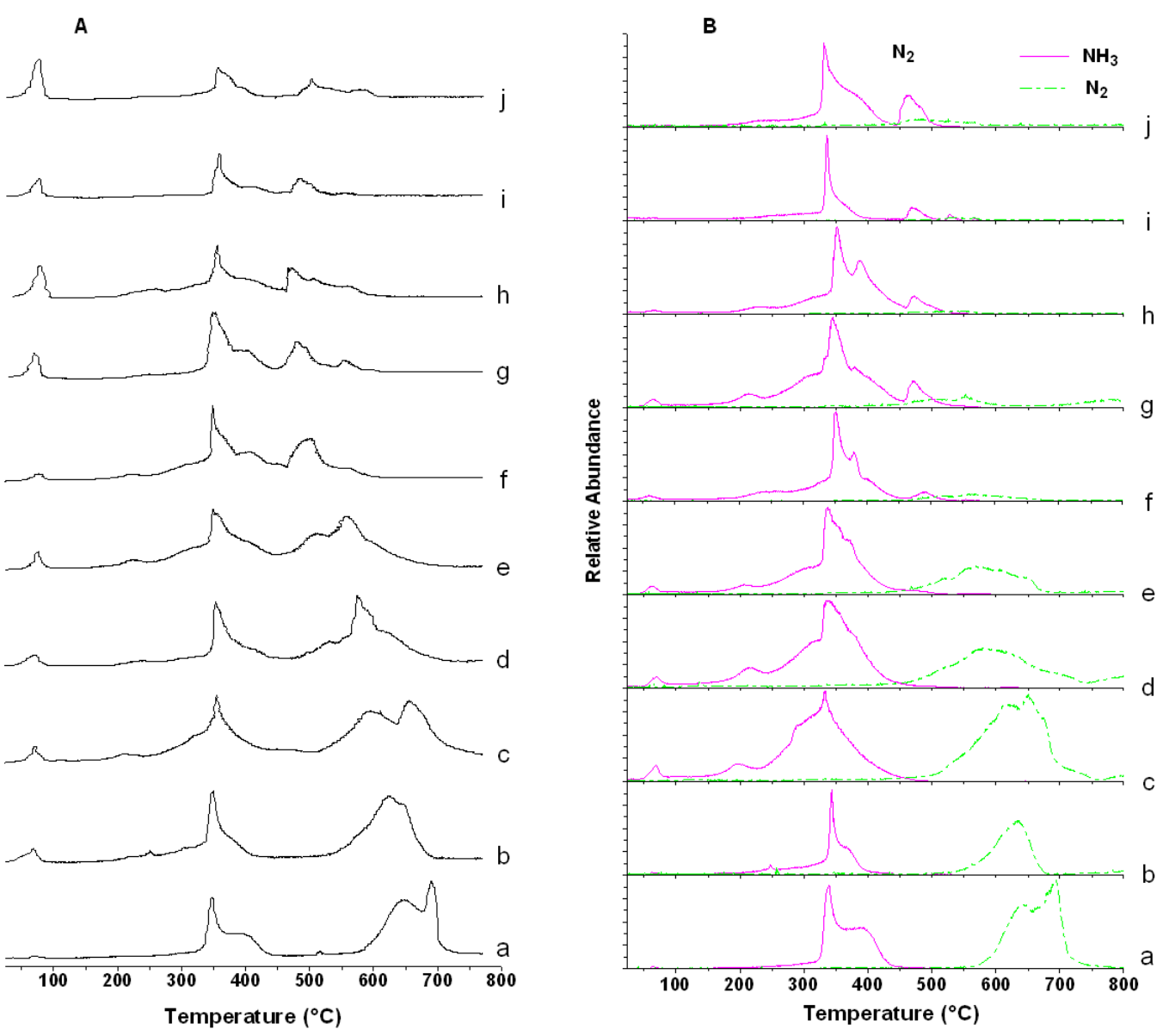

Figure 4.2 (A) TPD-TCD profiles and (B) TPD-MS profiles of LiCl-doped $\mathrm{LiNH}_{2}$

with various $\mathrm{LiNH}_{2} / \mathrm{LiCl}$ mole ratios: (a) pure $\mathrm{LiNH}_{2}$, (b) 9:1, (c) 8:2, (d) 7:3, (e) 6:4, (f) 5:5, (g) 4:6, (h) 3:7, (i) 2:8, and (j) 1:9.

Furthermore, $\mathrm{Cl}^{-}$exhibited even greater effect on the peaks at high temperature, namely, the two peaks at $645^{\circ} \mathrm{C}$ and $690{ }^{\circ} \mathrm{C}$ in the TPD profile of $\mathrm{LiNH}_{2}$ without $\mathrm{Cl}^{-}$merged into a broad one in that of $\mathrm{Cl}^{-}$-doped $\mathrm{LiNH}_{2}$. In addition, the peak-temperature decreased from 625 to $530{ }^{\circ} \mathrm{C}$ with increasing $\mathrm{LiCl}$ content. It is well-known that $\mathrm{LiCl}$ can form a eutectic liquid phase with another Li-based ionic compound below $500{ }^{\circ} \mathrm{C}$ [134]. Therefore, it is reasonable for us to believe that $\mathrm{LiCl}$ 
and $\mathrm{Li}_{2} \mathrm{NH}$ can form a eutectic liquid phase at about $500{ }^{\circ} \mathrm{C}$. As a result, $\mathrm{LiCl}$ and $\mathrm{Li}_{2} \mathrm{NH}$ have a good contact and thus $\mathrm{Cl}^{-}$can catalyze the decomposition of $\mathrm{Li}_{2} \mathrm{NH}$ via the formation of Cl-Li-N bonds. This catalytic performance of $\mathrm{Cl}^{-}$was further supported by the XRD measurements, which showed that $\mathrm{LiCl}$ was still present after the decomposition of $\mathrm{Li}_{2} \mathrm{NH}$ (Figure 4.3). It should be noted that there is little evidence of $\mathrm{Li}_{2} \mathrm{NH}$ on the XRD pattern above $400{ }^{\circ} \mathrm{C}$ (Figure 4.3 ), probably because $\mathrm{Li}_{2} \mathrm{NH}$ became amorphous due to the formation of its eutectic phase with $\mathrm{LiCl}$. 


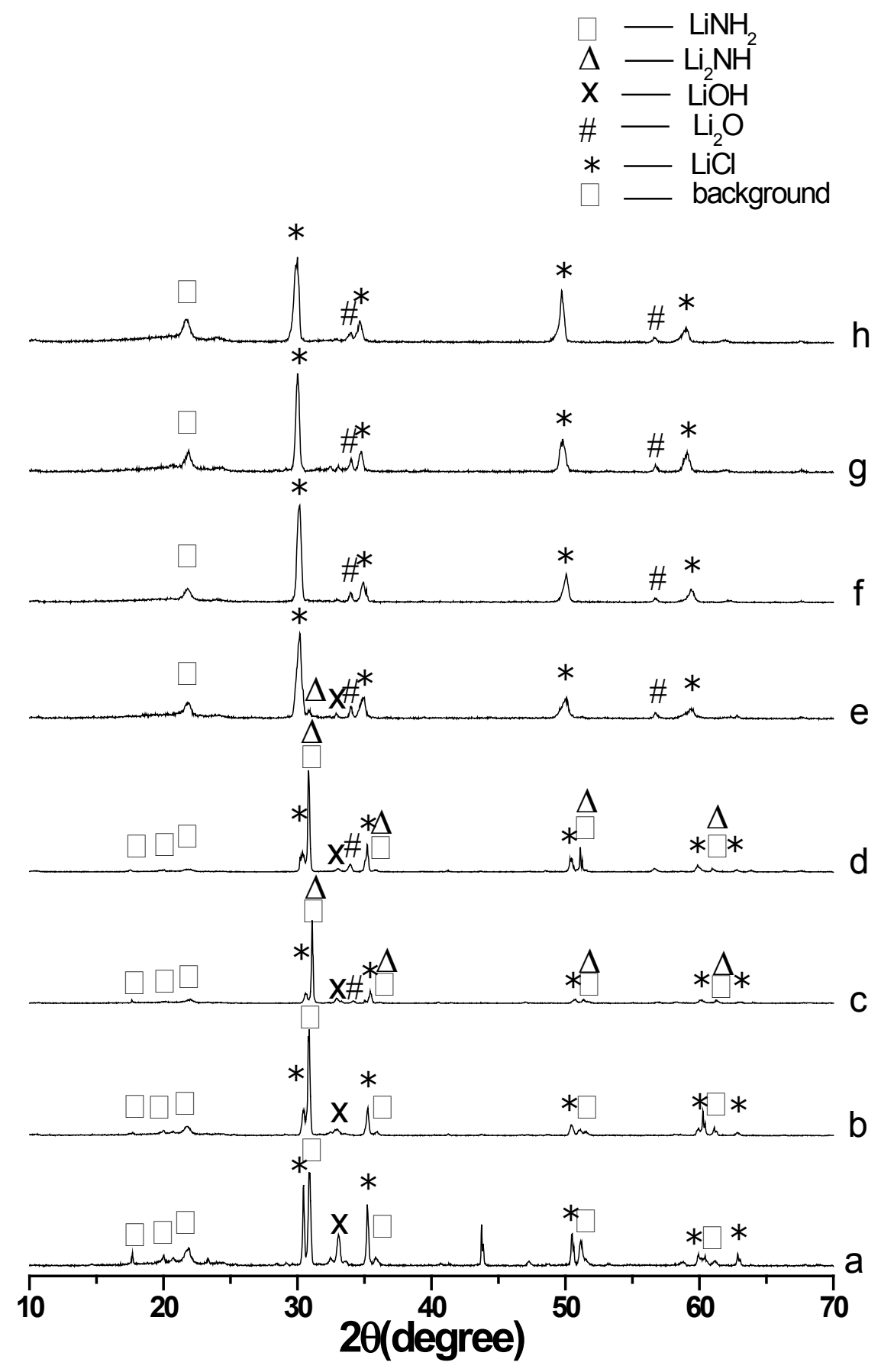

Figure 4.3 XRD patterns of the solid products from the TPD process of $\mathrm{LiNH}_{2} / \mathrm{LiCl}$ (8:2 molar ratio) that was stopped at various temperatures: (a) room temperature, (b) $160{ }^{\circ} \mathrm{C}$, (c) $275^{\circ} \mathrm{C}$, (d) $320^{\circ} \mathrm{C}$, (e) $330^{\circ} \mathrm{C}$, (f) $380{ }^{\circ} \mathrm{C}$, (g) $520^{\circ} \mathrm{C}$, and (h) $570{ }^{\circ} \mathrm{C}$. 


\subsection{Conclusion}

Chloride ion $\left(\mathrm{Cl}^{-}\right)$had great effects on the decompositions of $\mathrm{LiNH}_{2}$ and $\mathrm{Li}_{2} \mathrm{NH}$. The introduction of $\mathrm{Cl}^{-}$resulted in the generation of a new peak at low temperature of about $250{ }^{\circ} \mathrm{C}$ besides the original peak at $330{ }^{\circ} \mathrm{C}$ in the decomposition of $\mathrm{LiNH}_{2}$ into $\mathrm{Li}_{2} \mathrm{NH}$ and $\mathrm{NH}_{3}$. Furthermore, $\mathrm{Cl}^{-}$showed an even greater effect on the decomposition of $\mathrm{Li}_{2} \mathrm{NH}$, namely, the two peaks in TPD profiles merged into one and the peak temperature decrease from 645 to $530{ }^{\circ} \mathrm{C}$ with increasing molar ratio of $\mathrm{LiCl}$ to $\mathrm{LiNH}_{2}$.

Our hypothesis that the decomposition of $\mathrm{LiNH}_{2}$ may be promoted by anion promoter is true for introducing $\mathrm{Cl}^{-}$. 


\section{Chapter 5 Chemical stability of lithium nitride in air*}

\subsection{Introduction}

Lithium nitride $\left(\mathrm{Li}_{3} \mathrm{~N}\right)$ is attracting much attention for energy application. As a very reactive material, $\mathrm{Li}_{3} \mathrm{~N}$ could exothermically convert greenhouse gas $\mathrm{CO}_{2}$ to two valuable solid materials — carbon nitride $\left(\mathrm{C}_{3} \mathrm{~N}_{4}\right)$ and lithium cyanamide $\left(\mathrm{Li}_{2} \mathrm{CN}_{2}\right)$ compounds at temperature of $250{ }^{\circ} \mathrm{C}$ or above [135]. This would provide a novel process to control $\mathrm{CO}_{2}$ emissions.

The critic issue of hydrogen fuel economy is the lack of an efficient, safe, and low cost technique for hydrogen storage. The practical application of liquid hydrogen storage technology is limited by the large amount of energy consumed during liquefaction and the continuous hydrogen boil-off [2]. Compressed hydrogen in a cylinder, which is widely employed for hydrogen storage in laboratories, requires an ultrahigh pressure to achieve enough hydrogen fuel for a reasonable driving cycle of 300 miles, causing a safety issue [3]. For those reasons, hydrogen storage in solid materials is considered as the safest and most effective way of handling hydrogen for transportation application [136]. In the past 10 years, $\mathrm{Li}_{3} \mathrm{~N}$ was intensively investigated as hydrogen storage material [33-51].

\footnotetext{
*The material contained in this chapter was planned for submission to the journal Industrial and Engineering Chemistry Research by Junqing Zhang and Yun Hang $\mathrm{Hu}$.
} 
$\mathrm{Li}_{3} \mathrm{~N}$ possesses a very high $\mathrm{Li}^{+}$conductivity along layers perpendicular to the crystallographic c axis of $\alpha-\mathrm{Li}_{3} \mathrm{~N}$ [61-65]. TFherefore, $\mathrm{Li}_{3} \mathrm{~N}$ would be a promising material for lithium ion batteries.

Three phases $(\alpha, \beta$, and $\gamma)$ have been identified for $\operatorname{Li}_{3} \mathrm{~N}$. $\alpha-\mathrm{Li}_{3} \mathrm{~N}$ can be prepared by the reaction between $\mathrm{Li}$ and $\mathrm{N}_{2}$ at $400{ }^{\circ} \mathrm{C}$ [57]. Its structure was evaluated by Zintl and Brauer [58] and later revised by Rabenau and Schultz [59]. They revealed that $\alpha-\mathrm{Li}_{3} \mathrm{~N}$, which occupies the space group of $\mathrm{P} 6 / \mathrm{mmm}$ with $\mathrm{a}=$ 3.648(1) $\AA$ and $\mathrm{c}=3.875(1) \AA$, consists of $\mathrm{Li}_{2} \mathrm{~N}$ layers that are alternated by purelithium layers along $\mathrm{c}$ direction. However, $\alpha-\mathrm{Li}_{3} \mathrm{~N}$ contains intrinsic defects $(1-2 \% \mathrm{Li}$ vacancies) in the $\alpha-\mathrm{Li}_{2} \mathrm{~N}$ layers [66], leading to its high ionic conductivity. Furthermore, such a defect structure of $\alpha-\mathrm{Li}_{3} \mathrm{~N}$ creates its possibility for a pressureinduced phase transformation, namely, $\beta-\mathrm{Li}_{3} \mathrm{~N}$ can be produced via the phase transformation of $\alpha-\mathrm{Li}_{3} \mathrm{~N}$ at pressure of $0.4 \sim 4 \mathrm{GPa}[67,68]$. The $\beta-\mathrm{Li}_{3} \mathrm{~N}$ possesses a hexagonal structure in the $\mathrm{P} 6{ }_{3} / \mathrm{mmc}$ space group with $\mathrm{a}=3.552(1) \AA$ and $\mathrm{c}=6.311(3)$ $\AA(\mathrm{Z}=2)$ in which pure-lithium layers alternate $\mathrm{LiN}$ layers as opposed to the $\mathrm{Li}_{2} \mathrm{~N}$ layers in $\alpha$ phase [71]. The reverse phase transformation from $\beta-\mathrm{Li}_{3} \mathrm{~N}$ back to $\alpha-\mathrm{Li}_{3} \mathrm{~N}$ can take place by heat treatment at about $500{ }^{\circ} \mathrm{C}[70,71] \cdot \gamma-\mathrm{Li}_{3} \mathrm{~N}$, which is a cubic face-centered crystal compound, was predicted to be formed at ultra-high pressures $[69,72]$. Furthermore, the transformation of $\beta-\mathrm{Li}_{3} \mathrm{~N}$ to $\gamma-\mathrm{Li}_{3} \mathrm{~N}$ was observed in the pressure range of $36-45 \mathrm{GPa}[73]$.

The electronic and optical properties of $\mathrm{Li}_{3} \mathrm{~N}$ have been evaluated experimentally $[71,74,75]$ and theoretically [76-82]. However, to our best 
knowledge, the chemical stability of $\mathrm{Li}_{3} \mathrm{~N}$ in air, which is important for its energy application, has not been investigated. For this reason, in this work, the degradation of $\mathrm{Li}_{3} \mathrm{~N}$ in air was systematically explored by XRD, FT-IR, and UV-vis absorption. Furthermore, the difference of chemical stabilities between $\alpha-\mathrm{Li}_{3} \mathrm{~N}$ and $\beta-\mathrm{Li} 3 \mathrm{~N}$ was evaluated.

\subsection{Experiments}

\subsubsection{Treatment of $\mathrm{Li}_{3} \mathrm{~N}$ in $\mathrm{O}_{2}$}

$\mathrm{Li}_{3} \mathrm{~N}$ powder ( $\geq 99.5 \%$, Sigma-Aldrich), which was previously vacuumed for

degas at room temperature for $2 \mathrm{~h}$, was treated with $\mathrm{O}_{2}$ at pressure of 50 psi and a selected temperature $\left(170,230,280\right.$, or $\left.330^{\circ} \mathrm{C}\right)$ in a ceramic tube reactor for $3 \mathrm{~h}$.

\subsubsection{Degradation of $\mathrm{Li}_{3} \mathrm{~N}$ in air}

$\mathrm{Li}_{3} \mathrm{~N}$ powder $(\geq 99.5 \%$, Sigma-Aldrich) was exposed to air at room temperature. The sample at various exposure times was subjected to structure characterizations (see section 2.3) to monitor $\mathrm{Li}_{3} \mathrm{~N}$ degradation. 


\subsubsection{Characterization}

The UV-vis absorption spectra of $\mathrm{Li}_{3} \mathrm{~N}$ samples, which were previously treated in $\mathrm{O}_{2}$ or air, were recorded using a UV-vis spectrophotometer (Shimadzu, Model UV-2450, Figure 5.1) in the wavelength range of $200-800 \mathrm{~nm}$ at room temperature. Barium sulfate was used as a reference material. The X-ray diffraction (XRD) measurements for the samples were performed with a Scintag XDS2000 Powder Diffractometer equipped with a $\mathrm{Cu} \mathrm{K} \alpha$ source, at $45 \mathrm{kV}$ and $35 \mathrm{~mA}$ (Figure 2.3). The scanning speed and range were $1 \%$ min and $15-70^{\circ}$, respectively. $\mathrm{The}^{\mathrm{L}} \mathrm{Li}_{3} \mathrm{~N}$ samples were also subjected to Fourier transform infrared spectroscopy (FT-IR) measurements that were carried out using a Perkin Elmer Spectrum One FT-IR spectrometer (Figure 5.2). 


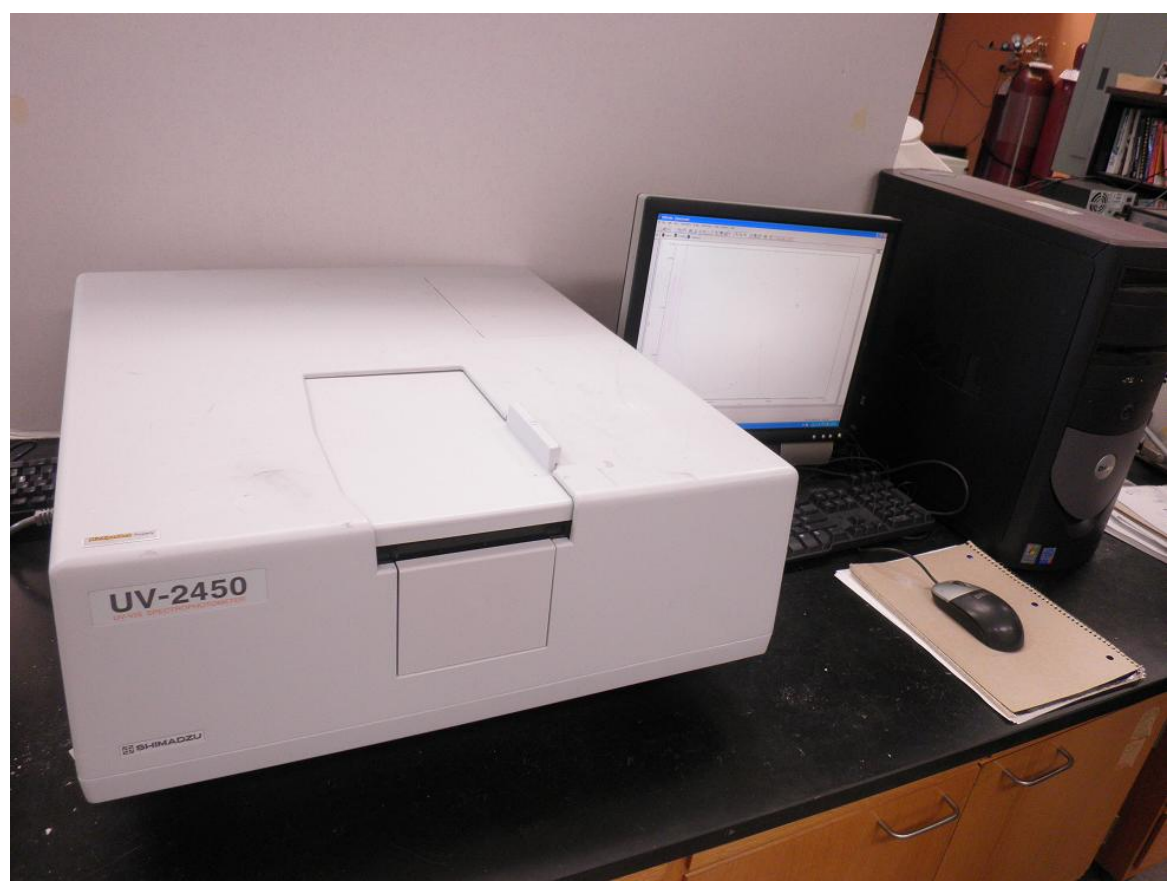

Figure 5.1 Shimadzu UV-2450 Spectrometer.

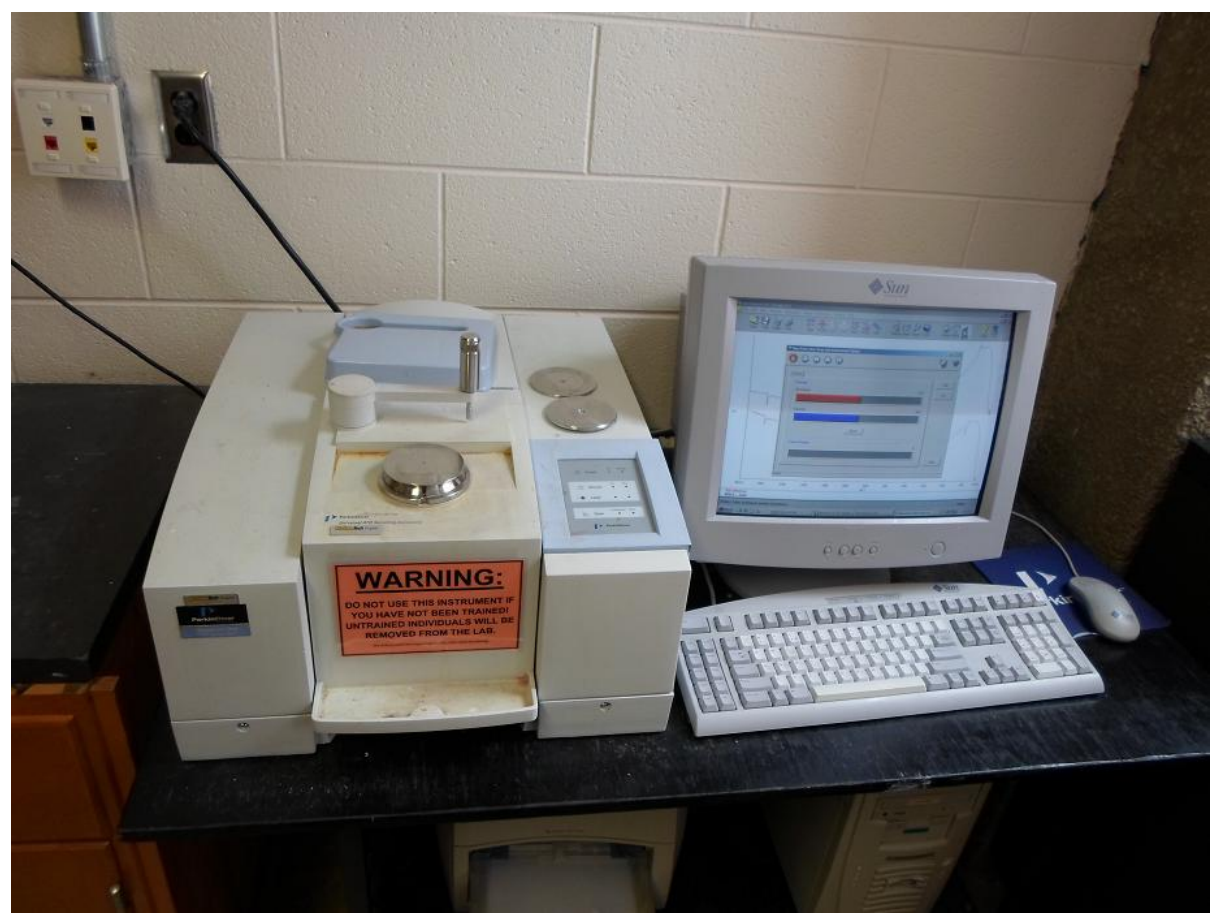

Figure 5.2 Perkin Elmer Spectrum One FTIR spectrometer. 


\subsection{Results and discussion}

\subsubsection{Oxidation of $\mathrm{Li}_{3} \mathrm{~N}$ in $\mathrm{O}_{2}$}

It is well-known that dry air contains $\mathrm{N}_{2}(78.084 \%$ volume $), \mathrm{O}_{2}(20.946 \%$ volume $), \operatorname{Ar}(0.934 \%$ volume $), \mathrm{CO}_{2}(0.035 \%$ volume $)$, and trace amount of other gases $(0.001 \%$ volume totally). Furthermore, common air is composed of dry air and $\mathrm{H}_{2} \mathrm{O}$ vapor ( $1-4 \%$ volume). The effect of trace gases on $\mathrm{Li}_{3} \mathrm{~N}$ is negligible due to their very small concentrations $\left(0.001 \%\right.$ volume totally in dry air). $\mathrm{N}_{2}$ and $\mathrm{CO}_{2}$ could not affect $\mathrm{Li}_{3} \mathrm{~N}$ at room temperature [135]. However, it is unclear whether $\mathrm{O}_{2}$ has effect on $\mathrm{Li}_{3} \mathrm{~N}$ at room temperature. To examine the effect, $\mathrm{Li}_{3} \mathrm{~N}$ was treated by $\mathrm{O}_{2}$ at various temperatures. As shown in Figure 5.3a, one can see that commercial $\mathrm{Li}_{3} \mathrm{~N}$ without any treatment contains $\alpha$ - and $\beta$-phases, which is consistent with the reported observations [71-73]. No new phase was formed by the $\mathrm{O}_{2}$ treatment at $170{ }^{\circ} \mathrm{C}$ (Figure 5.3b), indicating no reaction between $\mathrm{Li}_{2} \mathrm{O}$ and $\mathrm{O}_{2}$ at $170{ }^{\circ} \mathrm{C}$. However, when temperature was increased to 230 and $280{ }^{\circ} \mathrm{C}, \mathrm{O}_{2}$ can partially convert $\mathrm{Li}_{3} \mathrm{~N}$ into $\mathrm{Li}_{2} \mathrm{O}$ in $3 \mathrm{~h}$ (Figure $5.3 \mathrm{c}$ and d). Furthermore, $\mathrm{Li}_{3} \mathrm{~N}$ was completely converted into $\mathrm{Li}_{2} \mathrm{O}$ by $\mathrm{O}_{2}$ at $330{ }^{\circ} \mathrm{C}$ (Figure 5.3e). One can conclude that the oxidation of $\mathrm{Li}_{3} \mathrm{~N}$ in $\mathrm{O}_{2}$ can take place at temperature of $230{ }^{\circ} \mathrm{C}$ or higher. In other words, $\mathrm{Li}_{3} \mathrm{~N}$ is stale in $\mathrm{O}_{2}$ at room temperature. 


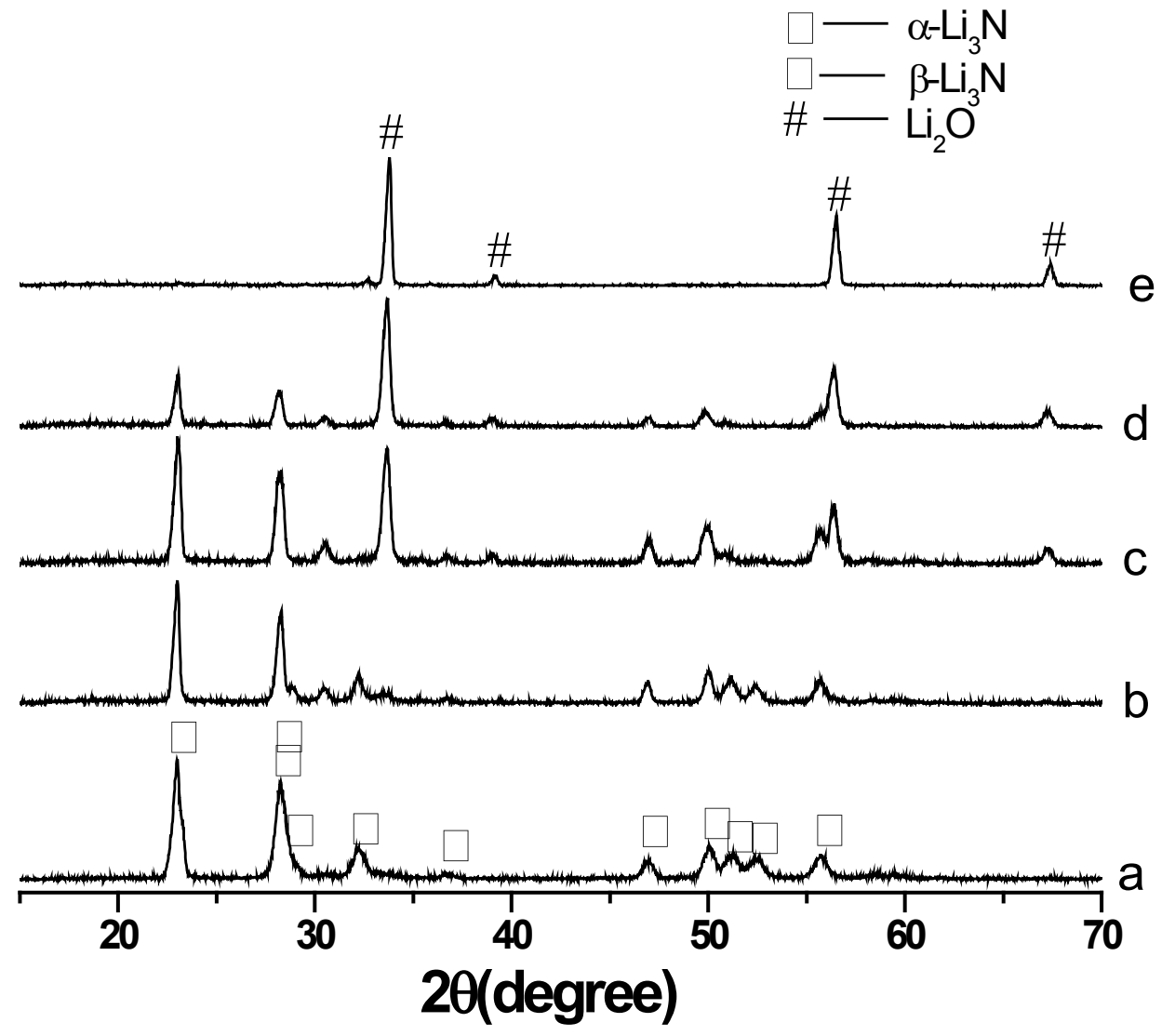

Figure 5.3 XRD patterns of $\mathrm{Li}_{3} \mathrm{~N}$ (a) without treatment and treated with $\mathrm{O}_{2}$ for $3 \mathrm{~h}$ at (b) $170{ }^{\circ} \mathrm{C}$, (c) $230{ }^{\circ} \mathrm{C}$, (d) $280{ }^{\circ} \mathrm{C}$, and (e) $330{ }^{\circ} \mathrm{C}$.

\subsubsection{Effect of $\mathrm{H}_{2} \mathrm{O}$ in air on $\mathrm{Li}_{3} \mathrm{~N}$}

In order to evaluate the effect of $\mathrm{H}_{2} \mathrm{O}$ vapor in air on $\mathrm{Li}_{3} \mathrm{~N}$ structure, XRD patterns were obtained for $\mathrm{Li}_{3} \mathrm{~N}$ powder samples, which were previously exposed to air with relative humility of $16 \%$. As shown in Figure 5.4, after exposing $\mathrm{Li}_{3} \mathrm{~N}$ to air, new phases of $\mathrm{LiOH}$ and $\mathrm{Li}_{2} \mathrm{CO}_{3}$ were formed. Furthermore, as exposure time increased, the relative intensity of $\mathrm{Li}_{2} \mathrm{CO}_{3}$ increased, whereas the relative intensity of 
$\mathrm{LiOH}$ first increased and then decreased. This indicates that $\mathrm{Li}_{2} \mathrm{CO}_{3}$ would be the product of reaction between $\mathrm{LiOH}$ and $\mathrm{CO}_{2}$. In addition, $\mathrm{NH}_{3}$ was smelled near $\mathrm{Li}_{3} \mathrm{~N}$ in air. Therefore, the degradation of $\mathrm{Li}_{3} \mathrm{~N}$ in air can be described as follows:

$$
\begin{aligned}
& \mathrm{Li}_{3} \mathrm{~N}+3 \mathrm{H}_{2} \mathrm{O}=3 \mathrm{LiOH}+\mathrm{NH}_{3} \\
& 2 \mathrm{LiOH}+\mathrm{CO}_{2}=\mathrm{Li}_{2} \mathrm{CO}_{3}+\mathrm{H}_{2} \mathrm{O}
\end{aligned}
$$

To reveal the degradation difference between $\beta-\mathrm{Li}_{3} \mathrm{~N}$ and $\alpha-\mathrm{Li}_{3} \mathrm{~N}$ in air, the molar ratios of $\beta-\mathrm{Li}_{3} \mathrm{~N}$ to $\alpha-\mathrm{Li}_{3} \mathrm{~N}$ at various exposure times were calculated from XRD diffraction peaks of $\beta-\mathrm{Li}_{3} \mathrm{~N}$ (103) and $\alpha-\mathrm{Li}_{3} \mathrm{~N}$ (111) by VOLFRACT program based on Cullity method [137]. The results are listed in Table 5.1, which shows that the molar ratio of $\beta-\mathrm{Li}_{3} \mathrm{~N}$ to $\alpha-\mathrm{Li}_{3} \mathrm{~N}$ of the $\mathrm{Li}_{3} \mathrm{~N}$ sample decreased with increasing exposure-time in air. This indicates that $\beta$ - $\mathrm{Li}_{3} \mathrm{~N}$ reacts with $\mathrm{H}_{2} \mathrm{O}$ faster than $\alpha-\mathrm{Li}_{3} \mathrm{~N}$. Therefore, $\alpha-\mathrm{Li}_{3} \mathrm{~N}$ is more stable than $\beta-\mathrm{Li}_{3} \mathrm{~N}$ in air. 


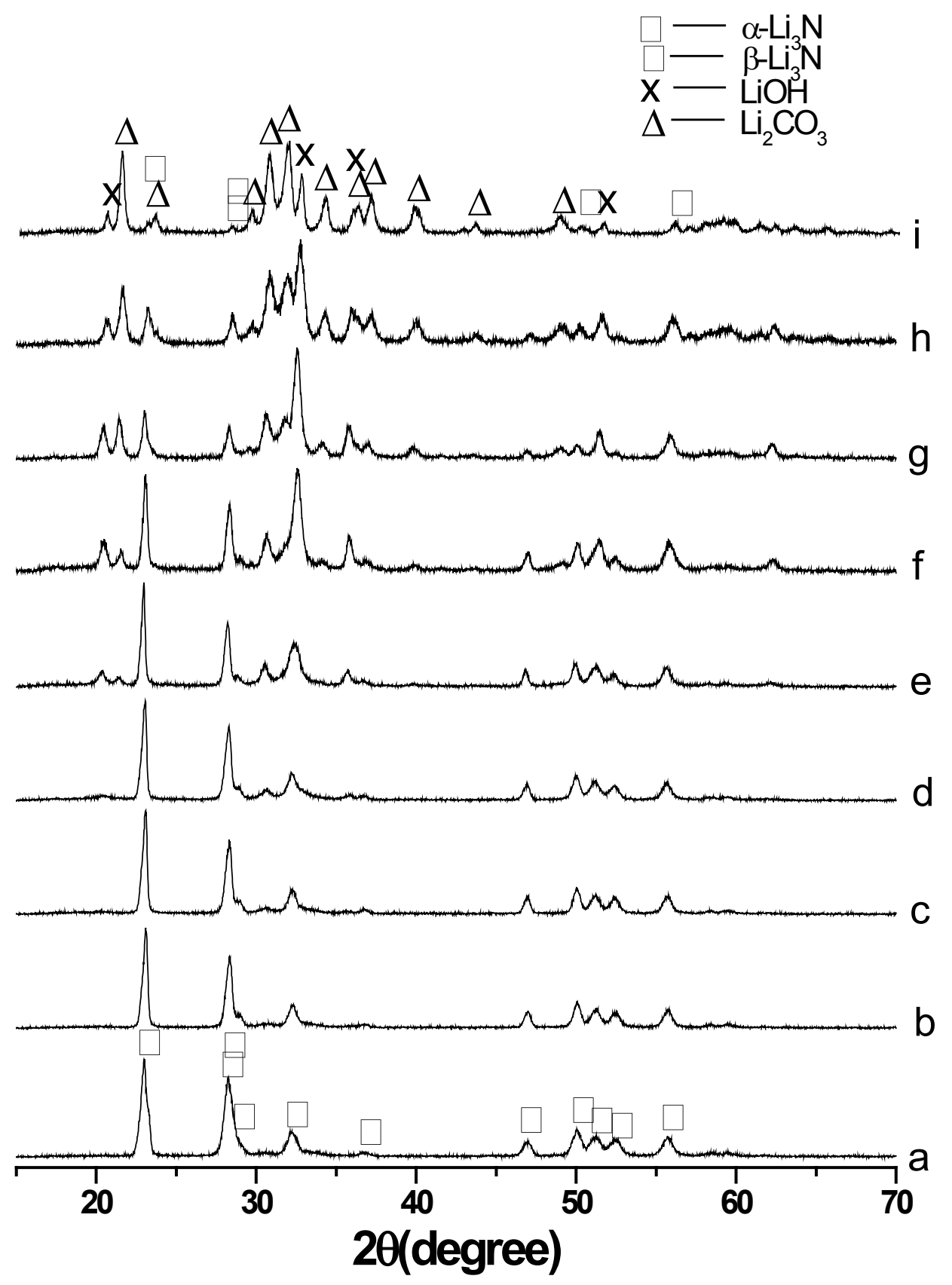

Figure 5.4 XRD patterns of $\mathrm{Li}_{3} \mathrm{~N}$ exposed to air for (a) $0 \mathrm{~min}$, (b) $15 \mathrm{~min}$, (c) $30 \mathrm{~min}$, (d) $1 \mathrm{~h}$, (e) $2 \mathrm{~h}$, (f) $4 \mathrm{~h}$, (g) $14 \mathrm{~h} \mathrm{(h)} 32 \mathrm{~h}$, and (i) $100 \mathrm{~h}$. 
Table 5.1 Molar ratio of $\beta-\mathrm{Li}_{3} \mathrm{~N}$ to $\alpha-\mathrm{Li}_{3} \mathrm{~N}$ in the $\mathrm{Li}_{3} \mathrm{~N}$ sample exposed to air.

\begin{tabular}{ll}
\hline Time in air (h) & Molar ratio of $\beta-\mathrm{Li}_{3} \mathrm{~N}$ to $\alpha-\mathrm{Li}_{3} \mathrm{~N}$ \\
\hline 0 & 0.448 \\
0.25 & 0.420 \\
0.5 & 0.378 \\
1 & 0.335 \\
2 & 0.238 \\
4 & 0.156 \\
14 & 0.050 \\
32 & 0.038 \\
100 & 0.027 \\
\hline
\end{tabular}

FT-IR spectra were also employed to evaluate the structure change of $\mathrm{Li}_{3} \mathrm{~N}$ due to its exposure to air. As shown in Figure 5.5a, one can see that $\mathrm{Li}_{3} \mathrm{~N}$ without exposure to air does not show any IR absorption in the frequency range of $800-4000$ $\mathrm{cm}^{-1}$. This happened because the electric vector perpendicular to the $\mathrm{z}$ axis of $\mathrm{Li}_{3} \mathrm{~N}$ exhibited IR absorption only in $200-800 \mathrm{~cm}^{-1}[138,139]$. After $\mathrm{Li}_{3} \mathrm{~N}$ was exposed to air, four absorption bands occurred at around $860,1088,1420$, and $3678 \mathrm{~cm}^{-1}$. The three absorption bands at 860,1088 , and $1420 \mathrm{~cm}^{-1}$, which are corresponding to the bending, symmetric stretching, and asymmetric stretching vibrations of $\mathrm{Li}_{2} \mathrm{CO}_{3}$, respectively $[140,141]$, indicate the formation of $\mathrm{Li}_{2} \mathrm{CO}_{3}$. The O-H stretching of 
LiOH can explain the IR absorption band at $3678 \mathrm{~cm}^{-1}$ [142]. Therefore, those FT-IR absorption bands supports the $\mathrm{XRD}$ results that the exposure of $\mathrm{Li}_{3} \mathrm{~N}$ to air generated $\mathrm{Li}_{2} \mathrm{CO}_{3}$ and $\mathrm{LiOH}$.

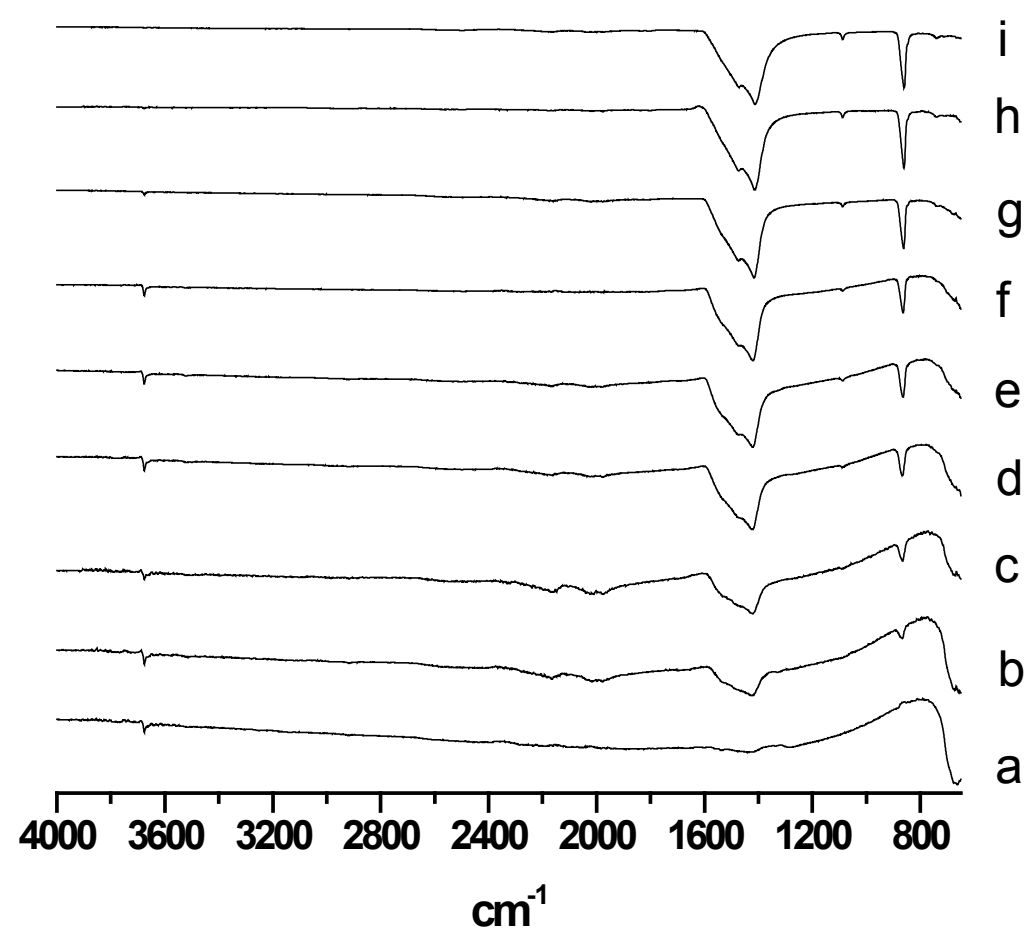

Figure 5.5 FTIR spectra of $\mathrm{Li}_{3} \mathrm{~N}$ exposed to air for (a) $0 \mathrm{~min}$, (b) $15 \mathrm{~min}$, (c) $30 \mathrm{~min}$, (d) $1 \mathrm{~h}$, (e) $2 \mathrm{~h}$, (f) $4 \mathrm{~h}$, (g) $14 \mathrm{~h}$ (h) $32 \mathrm{~h}$, and (i) $100 \mathrm{~h}$. 
UV-vis absorption spectra were recorded for $\mathrm{Li}_{3} \mathrm{~N}$ powder samples that were previously exposed to air (relative humility of $16 \%$ ) or wet air (relative humility of 88\%). As shown in Figure 5.6A and $\mathrm{B}$, the exposure of $\mathrm{Li}_{3} \mathrm{~N}$ to air caused a remarkably decrease in UV/visible absorption. This occurred because of formation of $\mathrm{LiOH}$ and $\mathrm{Li}_{2} \mathrm{CO}_{3}$, both of which have very low absorbance at the wavelength range of 400-800 nm (Figure 5.7). Furthermore, the higher humility causes the larger decrease in UV-vis absorbance of $\mathrm{Li}_{3} \mathrm{~N}$. This further supports the XRD and FT-IR results that $\mathrm{Li}_{3} \mathrm{~N}$ degradation in air is due to $\mathrm{H}_{2} \mathrm{O}$ vapor.
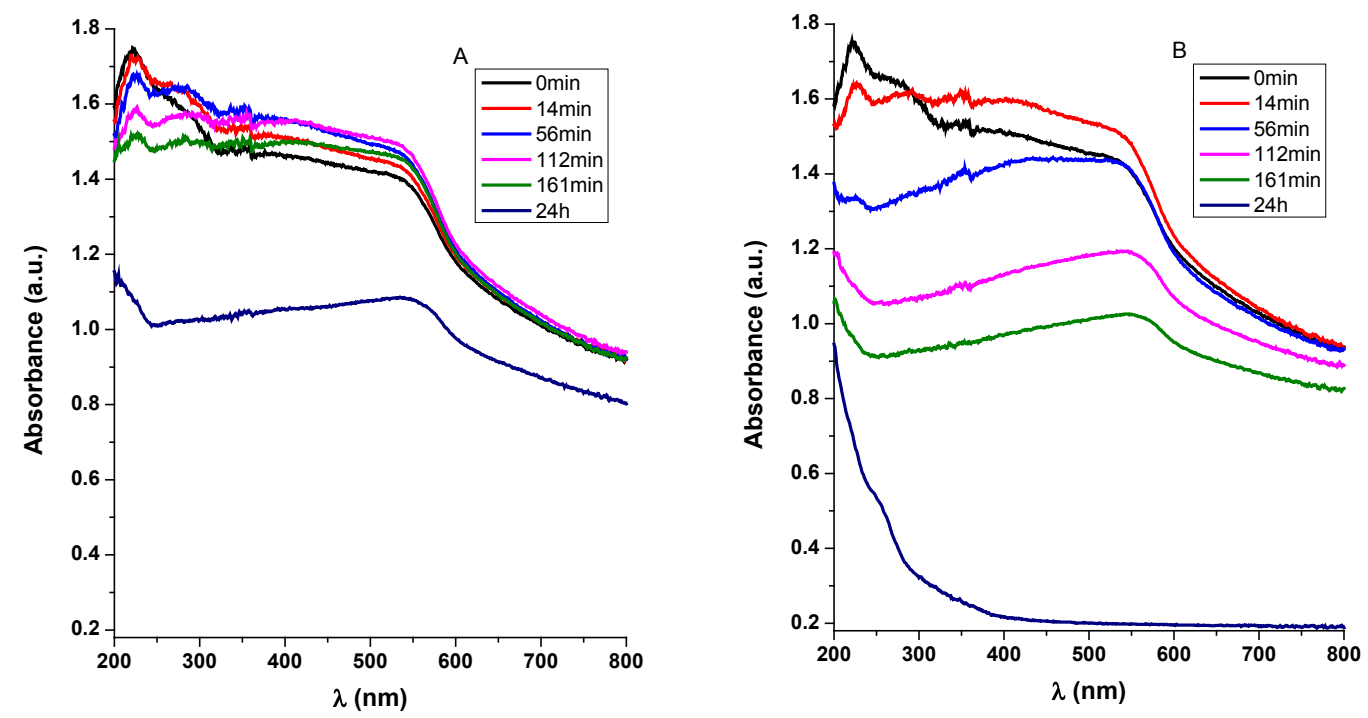

Figure 5.6 UV-vis absorption spectra of $\mathrm{Li}_{3} \mathrm{~N}$ exposed to (A) air with relative humidity of $16 \%$ and (B) air with relative humidity of $88 \%$. 


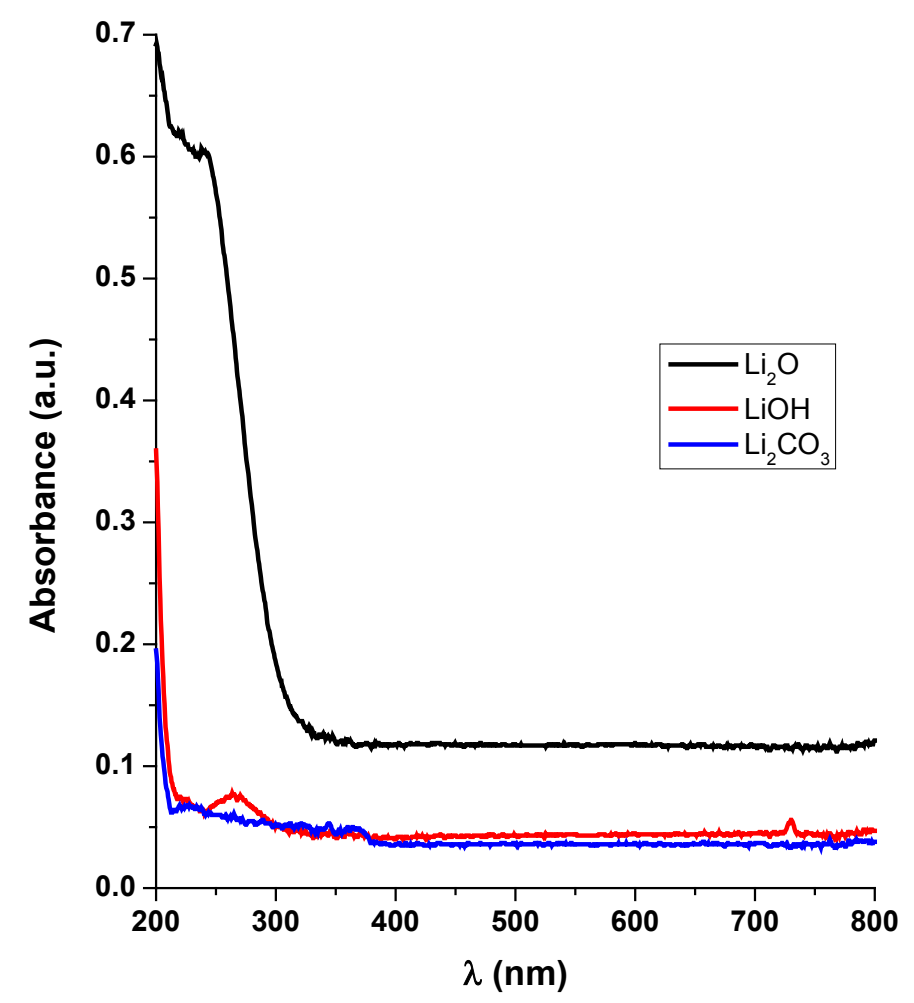

Figure 5.7 UV-vis absorption spectra of individual $\mathrm{Li}_{2} \mathrm{O}, \mathrm{LiOH}$, and $\mathrm{Li}_{2} \mathrm{CO}_{3}$.

\subsection{Conclusion}

The degradation of $\mathrm{Li}_{3} \mathrm{~N}$ in air was evaluated by XRD, FT-IR, and UV-vis absorption. $\mathrm{O}_{2}$ had no effect on $\mathrm{Li}_{3} \mathrm{~N}$ at room temperature, because the reaction between $\mathrm{Li}_{3} \mathrm{~N}$ and $\mathrm{O}_{2}$ requires a temperature of $230{ }^{\circ} \mathrm{C}$ or higher. However, $\mathrm{Li}_{3} \mathrm{~N}$ exhibited a high reactivity with $\mathrm{H}_{2} \mathrm{O}$ vapor in air at room temperature, leading to the conversion of $\mathrm{Li}_{3} \mathrm{~N}$ to $\mathrm{LiOH}$ and then to $\mathrm{Li}_{2} \mathrm{CO}_{3}$. Furthermore, it was found that 
degradation of $\beta-\mathrm{Li}_{3} \mathrm{~N}$ in air was much faster than $\alpha-\mathrm{Li}_{3} \mathrm{~N}$. This indicates that $\alpha-\mathrm{Li}_{3} \mathrm{~N}$ is more stable than $\beta-\mathrm{Li}_{3} \mathrm{~N}$ in air. 


\section{Chapter 6 Chemical stability of lithium nitride}

\section{bromide $\mathrm{Li}_{13} \mathrm{~N}_{4} \mathrm{Br}$ in air *}

\subsection{Introduction}

Battery technology has been playing a key role in modern society because it can be used to power electric and hybrid electric vehicles and to store wind and solar energy in smart grids [143]. Lithium superionic conductors have a promising prospect of making solid state high energy density battery systems. Special attentions have been paid to lithium nitride $\left(\mathrm{Li}_{3} \mathrm{~N}\right)$ because $\mathrm{Li}_{3} \mathrm{~N}$ has shown high $\mathrm{Li}^{+}$ conductivity as a potential solid electrolyte [61-65]. However, the thermodynamic decomposition voltage of $\mathrm{Li}_{3} \mathrm{~N}$ is relatively low at room temperature $(0.44 \mathrm{~V})$ and it decreases rapidly with the temperature increasing [103]. Therefore, the applicability of binary $\mathrm{Li}_{3} \mathrm{~N}$ as a solid state electrolyte at elevated temperatures is limited. This has led to the investigation of a series of ternary lithium nitrides which may compensate for this disadvantage.

\footnotetext{
*The material contained in this chapter was planned for submission to the journal Industrial and Engineering Chemistry Research by Junqing Zhang and Yun Hang $\mathrm{Hu}$.
} 
One approach was to partially substitute $\mathrm{Li}^{+}$cation of the binary $\mathrm{Li}_{3} \mathrm{~N}$ with other cations which often have a different valence to increase the disorder or to form new structures, e.g. $\mathrm{Li}_{3} \mathrm{AlN}_{2}$ has a cubic anti-fluorite type structure with decomposition voltage of $0.85 \mathrm{~V}$ at $104{ }^{\circ} \mathrm{C}$ [144]. Another approach was to partially substitute $\mathrm{N}^{3-}$ anion of the binary $\mathrm{Li}_{3} \mathrm{~N}$ with other anions, e.g. $\mathrm{Li}_{13} \mathrm{~N}_{4} \mathrm{Br}$ has a decomposition voltage over $1.3 \mathrm{~V}$ at $146{ }^{\circ} \mathrm{C}$ and $0.65 \mathrm{~V}$ at $300{ }^{\circ} \mathrm{C}$ [86].

The chemical stability of materials in air is important for guiding how to deal with the materials while being used $[145,146]$. For example, a high reactivity of layered lithium cobalt nitride $\mathrm{Li}_{2.13} \mathrm{Co}_{0.43} \mathrm{~N}$ with air moisture is found with the rapid appearance of lithium hydroxide and finally leads to the degradation of the nitride into lithium carbonate $\left(\mathrm{Li}_{2} \mathrm{CO}_{3}\right)$, cobalt hydroxide $\left(\mathrm{Co}(\mathrm{OH})_{2}\right)$ and the release of gaseous ammonia $\left(\mathrm{NH}_{3}\right)$ [145]. This suggests handling of $\mathrm{Li}_{2.13} \mathrm{Co}_{0.43} \mathrm{~N}$ anodic material in dry air would not damage its electrochemical properties [145]. However, the chemical stability of $\mathrm{Li}_{13} \mathrm{~N}_{4} \mathrm{Br}$ in air has never been studied. In this research, the corrosion process of $\mathrm{Li}_{13} \mathrm{~N}_{4} \mathrm{Br}$ in air is investigated by XRD, TPD-MS, and UV-vis absorption as a function of time. The $\mathrm{Li}_{13} \mathrm{~N}_{4} \mathrm{Br}$ degradation in air reaction order and the energy gap of $\mathrm{Li}_{13} \mathrm{~N}_{4} \mathrm{Br}$ was evaluated by the UV-vis absorption data. 


\subsection{Experiments}

\subsubsection{Lithium nitride bromide $\mathrm{Li}_{13} \mathrm{~N}_{4} \mathrm{Br}$ preparation}

Lithium nitride powder (99.5\%) and lithium bromide reagent (99.9+ \%), which had been purchased from Aldrich Chemical Co., were used without any further purification. $80 \mathrm{~mol} \%$ lithium nitride and $20 \mathrm{~mol} \%$ lithium bromide were mixed by an agate mortar and pestle for $10 \mathrm{~min}$ in an argon filled glove box to protect from moisture. The mixture was placed into a $1 / 4$-inch- diameter copper tube with one end sealed. The surface of the powder was pressed with a stick by hand. The sample was vacuumed for 2 hours at room temperature and then closed the system. Finally, it was annealed at $400{ }^{\circ} \mathrm{C}$ for 20 hours. X-ray diffraction pattern of the resulting sample indicated the formation of the pure lithium nitride bromide $\mathrm{Li}_{13} \mathrm{~N}_{4} \mathrm{Br}$ phase (Figure 6.1a).

\subsubsection{X-ray diffraction (XRD)}

The XRD measurements were performed with a Scintag XDS2000 Powder Diffractometer equipped with a $\mathrm{Cu} \mathrm{K} \alpha$ source, at $45 \mathrm{kV}$ and $35 \mathrm{~mA}$ (Figure 2.3). The scanning speed was $1 \%$ min and the scanning range was $10-60^{\circ} . \mathrm{Li}_{13} \mathrm{~N}_{4} \mathrm{Br}$ sample was covered with plastic wrap during the XRD measurements to prevent from 
absorbing $\mathrm{H}_{2} \mathrm{O}$ in air. The sample was tested by XRD repeatedly between intervals the sample was exposed in air.

\subsubsection{Temperature-programmed decomposition mass spectroscopy (TPD-MS)}

The temperature-programmed decomposition mass spectroscopy (TPD-MS) of $\mathrm{Li}_{13} \mathrm{~N}_{4} \mathrm{Br}$ sample was carried out as follows: a suitable amount of sample was loaded into a stainless steel tube reactor, which was located in an electric tube furnace. The temperature of the reactor was increased to $850{ }^{\circ} \mathrm{C}$ at a rate of $10{ }^{\circ} \mathrm{C} / \mathrm{min}$ from room temperature. Helium $(30 \mathrm{~mL} / \mathrm{min})$ was employed as a carrier gas through the reactor to bring the gaseous product(s) of the decomposition into a mass spectrometer (HP 5970 series mass selective detector, Figure 2.2) generating a TPD-MS profile. The masses from 27.7 to 28.7 were used to detect $\mathrm{N}_{2}$; the masses from 16.7 to 17.7 were used to detect $\mathrm{NH}_{3}$; the masses from 17.7 to 18.7 were used to detect $\mathrm{H}_{2} \mathrm{O}$; the masses from 43.7 to 44.7 were used to detect $\mathrm{CO}_{2}$. The sample was tested by TPD-MS repeatedly between intervals that the sample was exposed in air. 


\subsubsection{Ultraviolet-visible (UV-vis) absorption}

The UV-vis absorption spectra of sample powder were recorded repeatedly with exposing the sample in air for certain intervals, using a UV/vis spectrophotometer (Shimadzu, Model UV-2450, Figure 5.1) in the wavelength range of $200-800 \mathrm{~nm}$ at room temperature. Barium sulfate was used as a reference material.

\subsection{Results and discussion}

\subsubsection{XRD and TPD-MS analysis}

To observe the structure change of $\mathrm{Li}_{13} \mathrm{~N}_{4} \mathrm{Br}$ in air, $\mathrm{XRD}$ was conducted. As shown in Figure 6.1, the XRD pattern of the newly made $\mathrm{Li}_{13} \mathrm{~N}_{4} \mathrm{Br}$ was in agreement with the literature data [88]. After exposing $\mathrm{Li}_{13} \mathrm{~N}_{4} \mathrm{Br}$ to air, new phases of $\mathrm{LiBrO}_{2}$, $\alpha-\mathrm{Li}_{3} \mathrm{~N}, \mathrm{LiOH}$ and $\mathrm{Li}_{2} \mathrm{CO}_{3}$ were observed. With increasing the exposing time, the relative intensity of $\mathrm{LiBrO}_{2}$ kept increasing, while $\alpha-\mathrm{Li}_{3} \mathrm{~N}$ phase was observed during the first two hours and disappeared afterwards. This indicates that $\mathrm{LiBrO}_{2}$ was the final reaction product and $\mathrm{Li}_{3} \mathrm{~N}$ was the middle reaction product. The $\mathrm{O}$ in $\mathrm{LiBrO}_{2}$ should be from $\mathrm{O}_{2}$ in the air. Thus, the reaction can be expressed as:

$$
\mathrm{Li}_{13} \mathrm{~N}_{4} \mathrm{Br}+\mathrm{O}_{2}=4 \mathrm{Li}_{3} \mathrm{~N}+\mathrm{LiBrO}_{2}
$$


As shown in Figure 6.1, the relative intensity of $\mathrm{LiOH}$ first increased and then decreased whereas the relative intensity of $\mathrm{Li}_{2} \mathrm{CO}_{3}$ increased. This indicates that $\mathrm{Li}_{2} \mathrm{CO}_{3}$ would be the product of reaction between $\mathrm{LiOH}$ and $\mathrm{CO}_{2}$. In addition, $\mathrm{NH}_{3}$ was smelled near $\mathrm{Li}_{13} \mathrm{~N}_{4} \mathrm{Br}$ in air. Therefore, the degradation of $\mathrm{Li}_{3} \mathrm{~N}$ from $\mathrm{Li}_{13} \mathrm{~N}_{4} \mathrm{Br}$ in air can be described as follows:

$$
\begin{aligned}
& \mathrm{Li}_{3} \mathrm{~N}+3 \mathrm{H}_{2} \mathrm{O}=3 \mathrm{LiOH}+\mathrm{NH}_{3} \\
& 2 \mathrm{LiOH}+\mathrm{CO}_{2}=\mathrm{Li}_{2} \mathrm{CO}_{3}+\mathrm{H}_{2} \mathrm{O}
\end{aligned}
$$



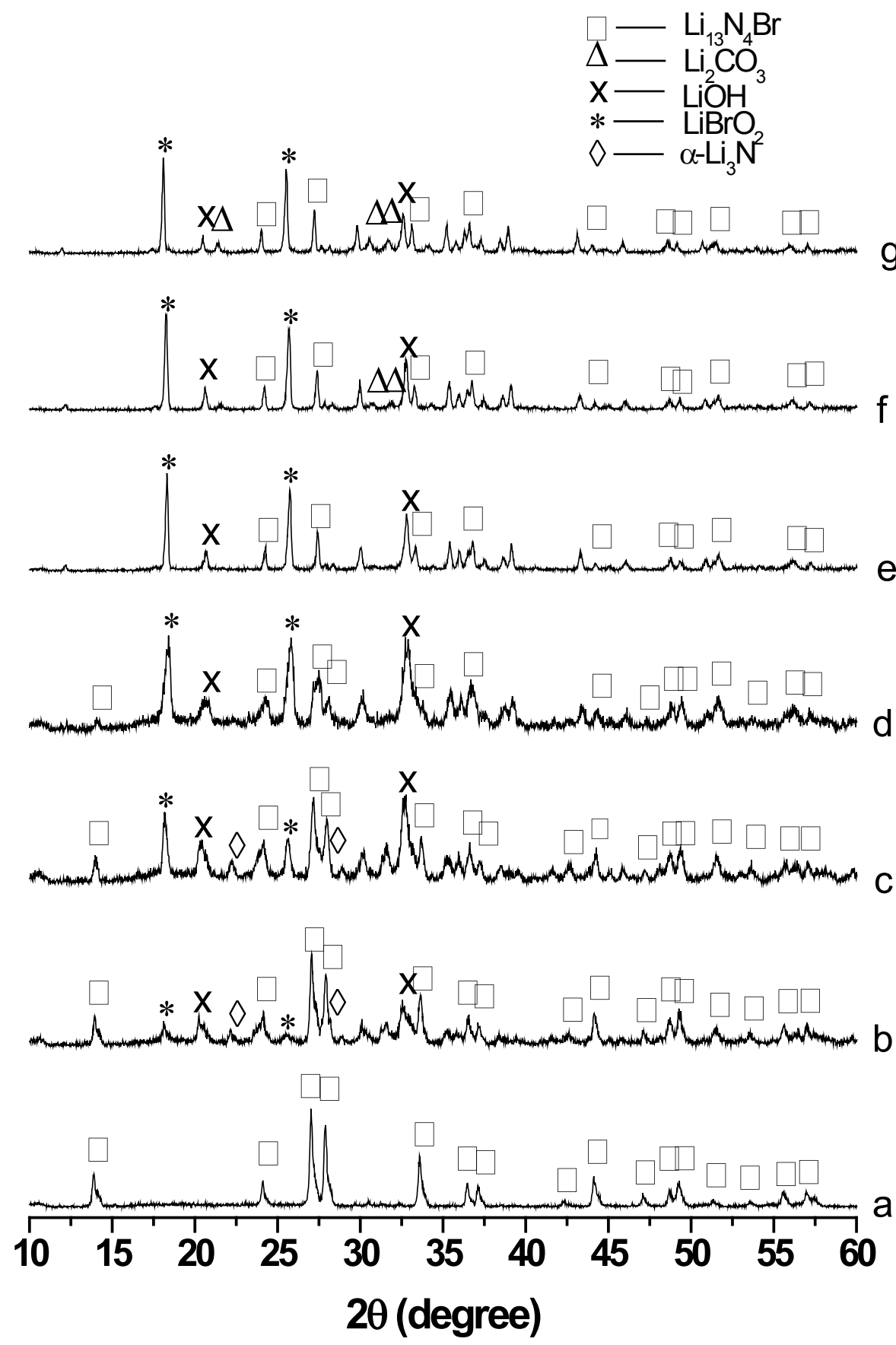

Figure 6.1 XRD patterns of $\mathrm{Li}_{13} \mathrm{~N}_{4} \mathrm{Br}$ in air for various time before testing. (a) Newly made $\mathrm{Li}_{13} \mathrm{~N}_{4} \mathrm{Br}$, (b) $1 \mathrm{~h}$, (c) $2 \mathrm{~h}$, (d) 4h, (e) 14h, (f) $32 \mathrm{~h}$ and (g) $100 \mathrm{~h}$. 
The TPD-MS profiles showed that the decomposition of pure $\mathrm{Li}_{13} \mathrm{~N}_{4} \mathrm{Br}$ only generate $\mathrm{N}_{2}$ as gas product (Figure 6.2a). This can be explained by equation 6.4 :

$$
\mathrm{Li}_{13} \mathrm{~N}_{4} \mathrm{Br}=12 \mathrm{Li}+2 \mathrm{~N}_{2}+\mathrm{LiBr}
$$

When $\mathrm{Li}_{13} \mathrm{~N}_{4} \mathrm{Br}$ was exposed in air for 1 or $2 \mathrm{~h}$, the decomposition generated mainly $\mathrm{NH}_{3}$. This can be explained by equation 6.2 .

When $\mathrm{Li}_{13} \mathrm{~N}_{4} \mathrm{Br}$ was exposed in air for a longer time, the decomposition generated $\mathrm{H}_{2} \mathrm{O}$ and $\mathrm{CO}_{2}$.

The $\mathrm{H}_{2} \mathrm{O}$ peak was from the decomposition of $\mathrm{LiOH}$ (equation 6.5). As shown in Figure 6.2, the relative intensity of $\mathrm{H}_{2} \mathrm{O}$ was increasing first the decreasing afterwards. This is in agreement with the $\mathrm{LiOH}$ relative intensity change from its XRD patterns (Figure 6.1).

$$
2 \mathrm{LiOH}=\mathrm{Li}_{2} \mathrm{O}+\mathrm{H}_{2} \mathrm{O}
$$

The $\mathrm{CO}_{2}$ peak was from the decomposition of $\mathrm{Li}_{2} \mathrm{CO}_{3}$ (equation 6.6). The increasing of $\mathrm{CO}_{2}$ is in agreement with the increasing of $\mathrm{Li}_{2} \mathrm{CO}_{3}$ in the XRD patterns (Figure 6.1).

$$
\mathrm{Li}_{2} \mathrm{CO}_{3}=\mathrm{Li}_{2} \mathrm{O}+\mathrm{CO}_{2}
$$




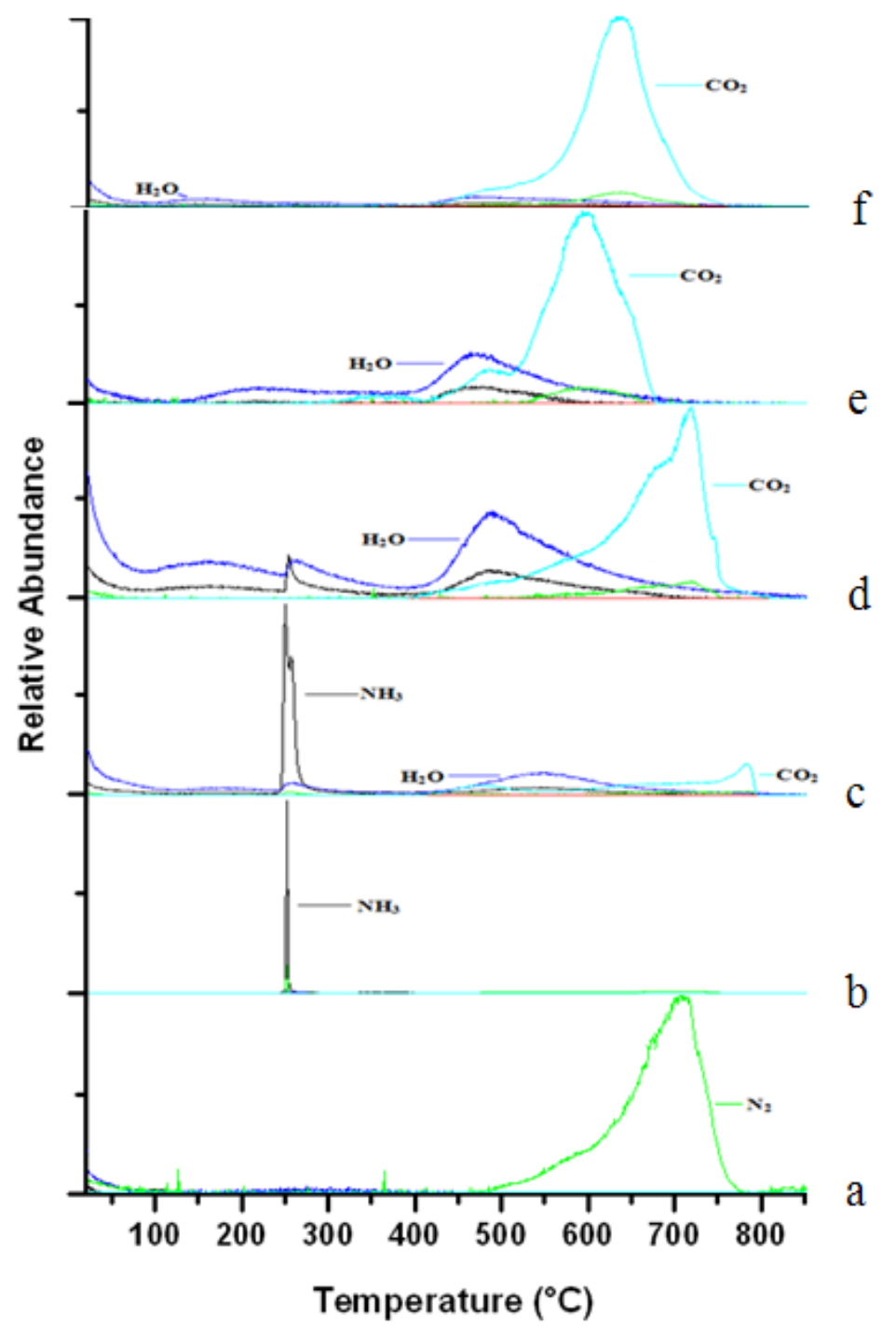

Figure 6.2 TPD-MS profile of $\mathrm{Li}_{13} \mathrm{~N}_{4} \mathrm{Br}$ in air for (a) $0 \mathrm{~h}$, (b) $1 \mathrm{~h}$, (d) $6 \mathrm{~h}$, (d) $30 \mathrm{~h}$, (e) $46 \mathrm{~h}$, and (f) $150 \mathrm{~h}$. 


\subsubsection{UV-vis absorption analysis}

Newly made $\mathrm{Li}_{13} \mathrm{~N}_{4} \mathrm{Br}$ was bright brick red, but its color would get lighter and lighter when it was exposed in air. The UV-vis absorption spectra of $\mathrm{Li}_{13} \mathrm{~N}_{4} \mathrm{Br}$ powder were recorded repeatedly with exposing the sample in air for certain intervals, and the results were shown in Figure 6.3.

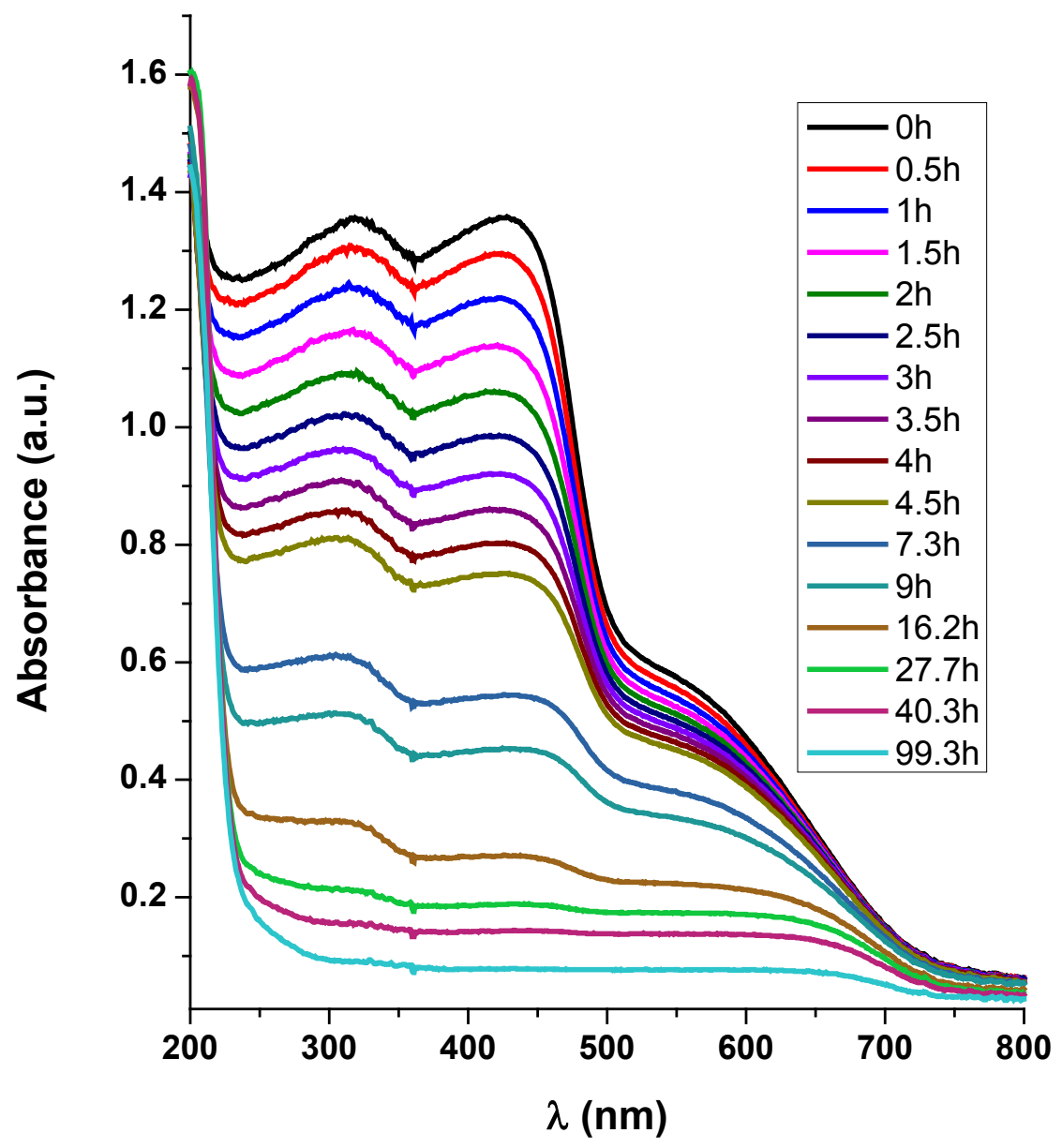

Figure 6.3 UV-vis absorption spectra of (A) $\mathrm{Li}_{13} \mathrm{~N}_{4} \mathrm{Br}$ and (B) $\alpha-\mathrm{Li}_{3} \mathrm{~N}$ in air for various time. 
As shown in Figure 6.3, at $\mathrm{t}=0 \mathrm{~h}$, one can see that the absorbance in the high wavelength (low photon energy) region is smaller than in the low wavelength (high photon energy) region. Spectrum shows a sharp edge between 430 to $530 \mathrm{~nm}$. The sharp absorption edge indicates the boundary of the energy of light a solid needed to stimulate electrons from valence band to conduction band. The first derivative of the UV-vis spectroscopy will generate a peak to obtain the energy gap [71, 147-149]. Sotelo-Lerma et al. used the first derivative of the UV-visible absorption spectrum of CdTe to determine its energy gap which is in excellent agreement with accepted values [147]. In addition, Riveros et al. justified the validity of the first derivative method. In this study, the first derivative spectra of $\mathrm{Li}_{13} \mathrm{~N}_{4} \mathrm{Br}$ were obtained from its UV-visible absorbance spectra by using the following equation.

$$
\frac{d A}{d(h v)}=\frac{d A}{d\left(\frac{h c}{\lambda}\right)}
$$

Where $\mathrm{A}$ is the absorbance (no unit), $\mathrm{h}$ is Planck constant $4.135667516(91) \times 10^{-15}(\mathrm{eV} \cdot \mathrm{s}), \mathrm{c}$ is the speed of light in vacuum $2.99792458 \times 10^{8}$ $(\mathrm{m} / \mathrm{s})$, and $\lambda$ is the wavelength of light $(\mathrm{m})$. Since we already know the relationship between $\mathrm{A}$ and $\lambda$, it's easy to get the relationship between $\mathrm{dA} / \mathrm{d}(\mathrm{hv})$ and hv (Figure 6.4), the energy gap $\mathrm{E}_{\mathrm{g}}(\mathrm{ev})$ is the energy at the peak position (Figure 6.4).

The calculated energy gap of $\mathrm{Li}_{13} \mathrm{~N}_{4} \mathrm{Br}$ in this study by the first derivative method is $2.61 \mathrm{eV}$. By using the data of the UV-vis absorption by $\mathrm{Li}_{13} \mathrm{~N}_{4} \mathrm{Br}$ sample 
in air for various time to calculate energy gap, it reached the same value, $\mathrm{E}_{\mathrm{g}}=2.61 \mathrm{eV}$ (Figure 6.4). It shows the existence of the $\mathrm{Li}_{13} \mathrm{~N}_{4} \mathrm{Br}$ in the sample even when it was exposed in air for $9 \mathrm{~h}$. Even though the concentration of $\mathrm{Li}_{13} \mathrm{~N}_{4} \mathrm{Br}$ had decreased with time, its energy gap could still be precisely calculated by its UV-vis absorption spectra, and the results were keeping the same.
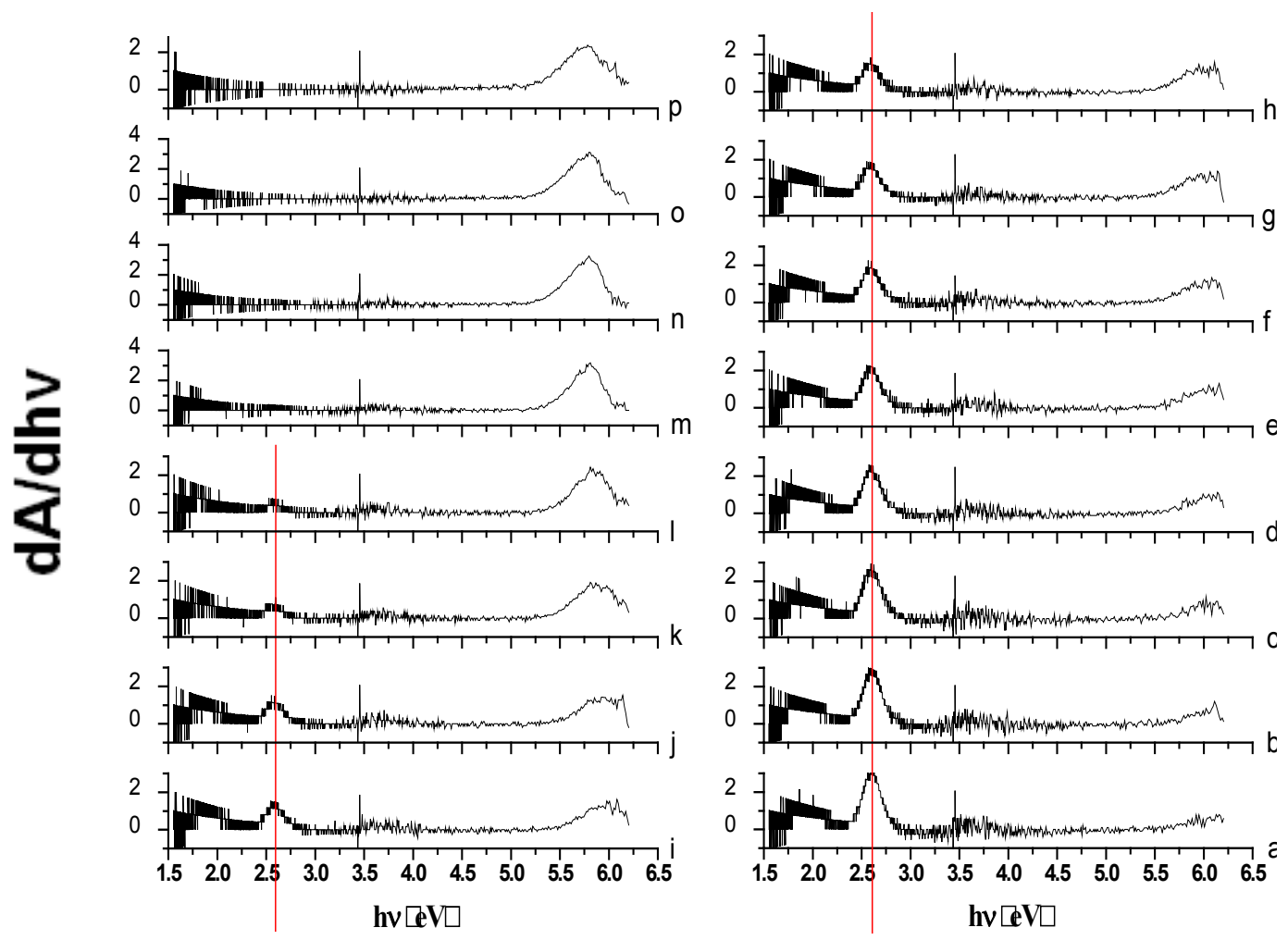

Figure 6.4 The energy gap calculation of sample $\mathrm{Li}_{13} \mathrm{~N}_{4} \mathrm{Br}$ in air for various time. (a)

Newly made $\mathrm{Li}_{13} \mathrm{~N}_{4} \mathrm{Br}$, (b) $0.5 \mathrm{~h}$, (c) $1 \mathrm{~h}$, (d) $1.5 \mathrm{~h}$, (e) $2 \mathrm{~h}$, (f) $2.5 \mathrm{~h}$, (g) $3 \mathrm{~h}$, (h) $3.5 \mathrm{~h}$, (i)

4h, (j) 4.5h, (k) 7.3h, (l) 9h, (m) 16.2h, (n) 27.7h, (o) 40.3h, (p) 99.3h. 
As shown in Figure 6.3, the absorption of the visible light wavelength between 250 and $800 \mathrm{~nm}$ by newly made $\mathrm{Li}_{13} \mathrm{~N}_{4} \mathrm{Br}$ is the biggest; the absorbance of this range decreased with time by exposing the sample in air.

All the solid products of the degradation of $\mathrm{Li}_{13} \mathrm{~N}_{4} \mathrm{Br}$, for example, $\mathrm{LiOH}$, $\mathrm{Li}_{2} \mathrm{CO}_{3}, \mathrm{LiBrO}_{2}$ are white; the absorbances of visible light by all these products are close to zero. Therefore, the absorbance of the visible light (390 to $750 \mathrm{~nm}$ ) was caused only by $\mathrm{Li}_{13} \mathrm{~N}_{4} \mathrm{Br}$ in the sample. According to Beer-Lambert law, the concentration of $\mathrm{Li}_{13} \mathrm{~N}_{4} \mathrm{Br}$ in the sample was proportional to its absorbance in the visible light range, the more the concentration of $\mathrm{Li}_{13} \mathrm{~N}_{4} \mathrm{Br}$ in the sample, the larger the absorbance of the visible light by $\mathrm{Li}_{13} \mathrm{~N}_{4} \mathrm{Br}$. We took the $428 \mathrm{~nm}$ absorbance (Figure 6.5) represent the concentration of $\mathrm{Li}_{13} \mathrm{~N}_{4} \mathrm{Br}$ in the sample and listed the concentration change with time (Table 6.1). 


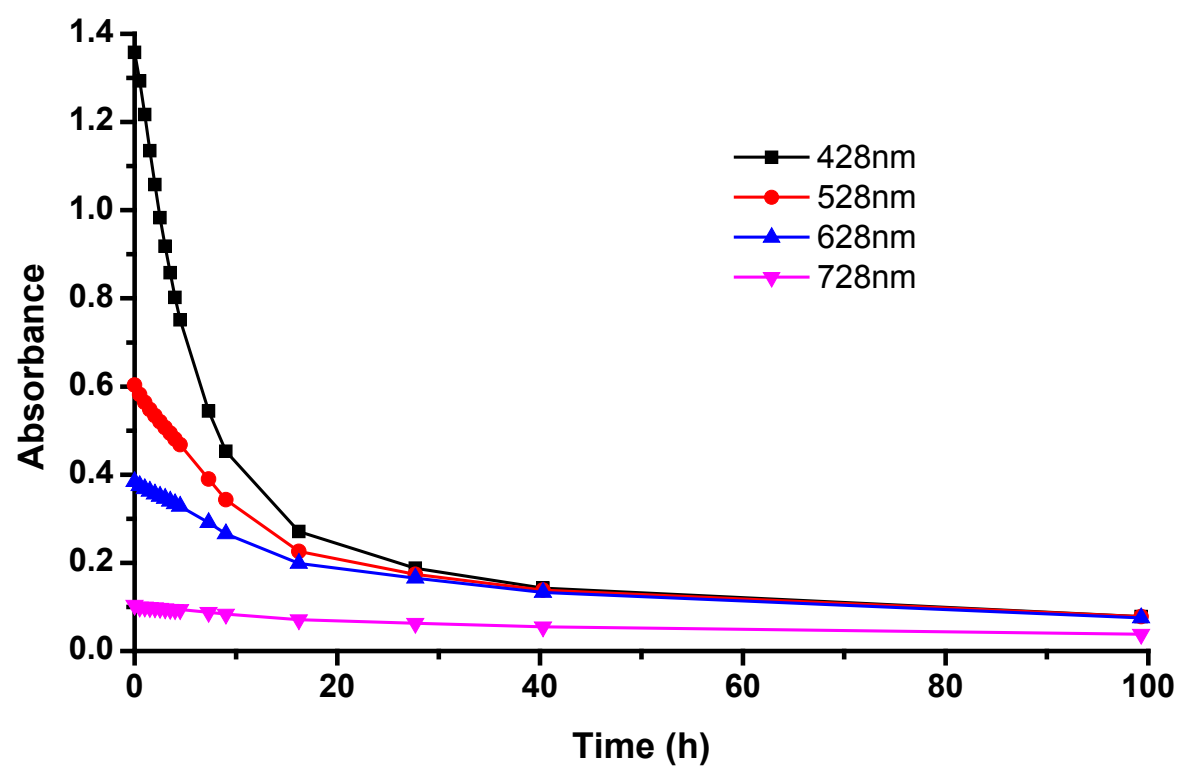

Figure $6.5 \mathrm{UV}$-vis absorption (at wavelength $428 \mathrm{~nm}, 528 \mathrm{~nm}, 628 \mathrm{~nm}$, and $728 \mathrm{~nm}$ ) of $\mathrm{Li}_{13} \mathrm{~N}_{4} \mathrm{Br}$ in air with time.

According to Polangi-Wagner model [118],

$$
-\frac{\mathrm{dN}}{\mathrm{dt}}=\mathrm{A} \exp \left(-\frac{\mathrm{E}_{\mathrm{a}}}{\mathrm{RT}}\right) \mathrm{N}^{\mathrm{n}}
$$

where $\mathrm{N}$ is the concentration of $\mathrm{Li}_{13} \mathrm{~N}_{4} \mathrm{Br}$ in the sample; $\mathrm{t}$ degradation time, A preexponential factor, $\mathrm{E}_{\mathrm{a}}$ degradation activation energy, $\mathrm{n}$ degradation order, $\mathrm{R}$ gas constant, and $\mathrm{T}$ absolute temperature. Because the degradation temperature was constant at room temperature, the whole part $A \exp \left(-\frac{E_{a}}{R T}\right)$ was constant, so equation 6.8 can be rewritten as

$$
-\frac{\mathrm{dN}}{\mathrm{dt}}=\mathrm{kN}^{\mathrm{n}}
$$


where $\mathrm{k}$ is constant.

Integrating both side of equation 6.9 can get

$$
\mathrm{kt}=\left[\begin{array}{cc}
-\left(\mathrm{N}-\mathrm{N}_{0}\right), & \text { when } \mathrm{n}=1 \\
\frac{1}{\mathrm{n}-1}\left(\frac{1}{\mathrm{~N}^{\mathrm{n}-1}}-\frac{1}{\mathrm{~N}_{0}{ }^{\mathrm{n}-1}}\right), & \text { when } \mathrm{n} \neq 1
\end{array}\right]
$$

where $\mathrm{N}_{0}$ is the concentration of $\mathrm{Li}_{13} \mathrm{~N}_{4} \mathrm{Br}$ before degradation in air. As we can see from equation 6.10 , the concentration of $\mathrm{Li}_{13} \mathrm{~N}_{4} \mathrm{Br}$ in the sample $\mathrm{N}$ can has a linear relationship with reaction time $\mathrm{t}$ by fitting the reaction order $\mathrm{n}$. Table 6.1 gives the reaction order fitting of the degradation of $\mathrm{Li}_{13} \mathrm{~N}_{4} \mathrm{Br}$ in air. Figure 6.6 and Figure 6.7 give the reaction order fitting of the degradation of $\mathrm{Li}_{13} \mathrm{~N}_{4} \mathrm{Br}$ in air: $\mathrm{N}-\mathrm{t}, \ln (\mathrm{N})-\mathrm{t}$, $1 / \mathrm{N}-\mathrm{t}, 1 / \mathrm{N}^{1.43}-\mathrm{t}$, and $1 / \mathrm{N}^{2}-\mathrm{t}$. As we can see, the reaction order $\mathrm{n}=2.43(\mathrm{n}-1=$ 1.43) is the best fitting. 
Table 6.1 Reaction order fitting of the degradation of $\mathrm{Li}_{13} \mathrm{~N}_{4} \mathrm{Br}$ in air.

\begin{tabular}{cccccc}
\hline time $(\mathrm{h})$ & $\mathrm{N}$ & $\operatorname{lnN}$ & $1 / \mathrm{N}$ & $1 / \mathrm{N}^{1.43}$ & $1 / \mathrm{N}^{2}$ \\
\hline 0.00 & 1.36 & 0.31 & 0.74 & 0.65 & 0.54 \\
0.50 & 1.29 & 0.26 & 0.77 & 0.69 & 0.60 \\
1.00 & 1.22 & 0.20 & 0.82 & 0.76 & 0.68 \\
1.50 & 1.14 & 0.13 & 0.88 & 0.83 & 0.78 \\
2.00 & 1.06 & 0.06 & 0.95 & 0.92 & 0.89 \\
2.50 & 0.98 & -0.02 & 1.02 & 1.02 & 1.03 \\
3.00 & 0.92 & -0.09 & 1.09 & 1.13 & 1.19 \\
3.50 & 0.86 & -0.15 & 1.17 & 1.24 & 1.36 \\
4.00 & 0.80 & -0.22 & 1.25 & 1.37 & 1.55 \\
4.50 & 0.75 & -0.29 & 1.33 & 1.51 & 1.77 \\
7.33 & 0.54 & -0.61 & 1.84 & 2.39 & 3.38 \\
9.00 & 0.45 & -0.79 & 2.21 & 3.10 & 4.87 \\
16.17 & 0.27 & -1.31 & 3.69 & 6.47 & 13.62 \\
27.67 & 0.19 & -1.67 & 5.32 & 10.91 & 28.29 \\
40.33 & 0.14 & -1.94 & 6.99 & 16.14 & 48.90 \\
99.33 & 0.08 & -2.55 & 12.82 & 38.40 & 164.37 \\
\hline & & & & &
\end{tabular}




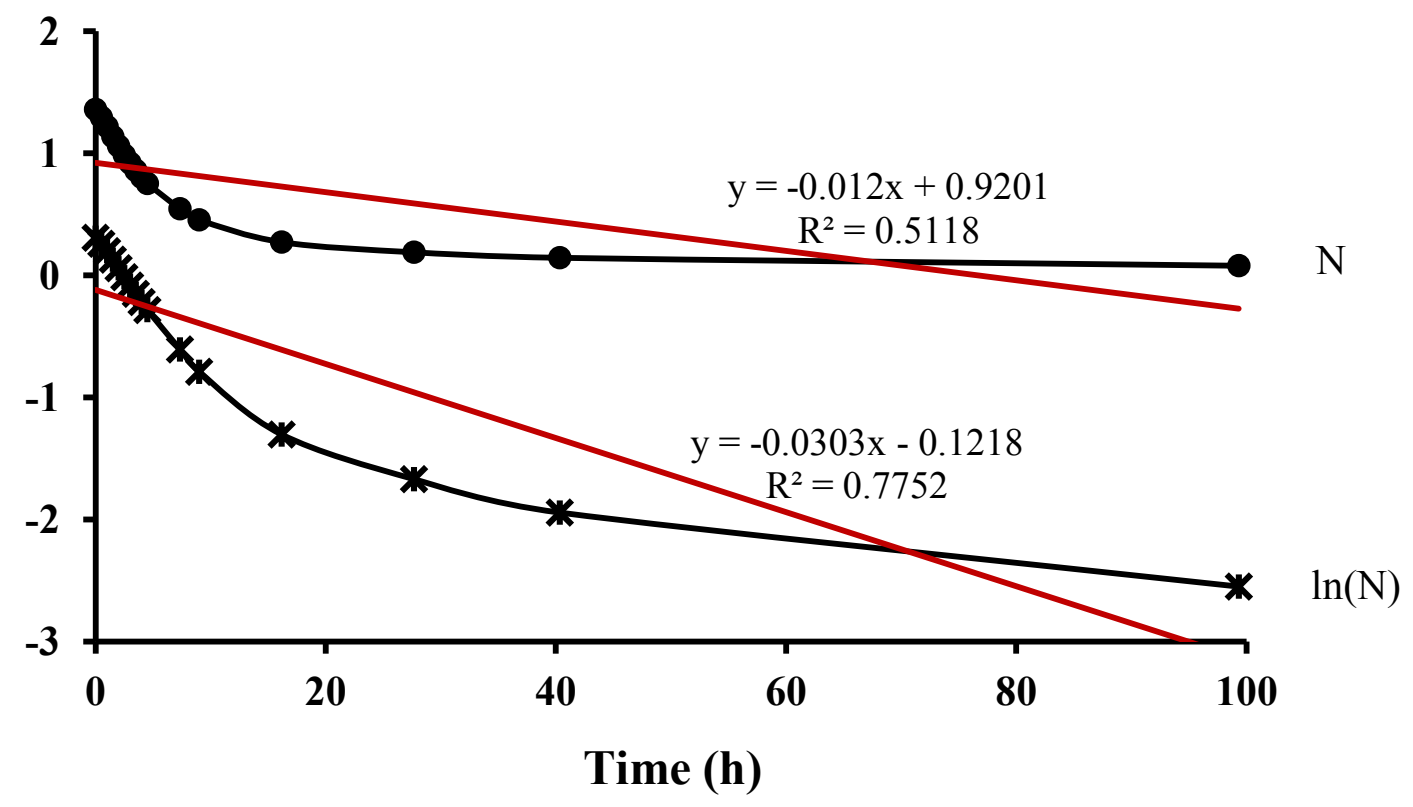

Figure 6.6 Reaction order fitting of the degradation of $\mathrm{Li}_{13} \mathrm{~N}_{4} \mathrm{Br}$ in air: $\mathrm{N}-\mathrm{t}$ and $\ln (\mathrm{N})-\mathrm{t}$. 


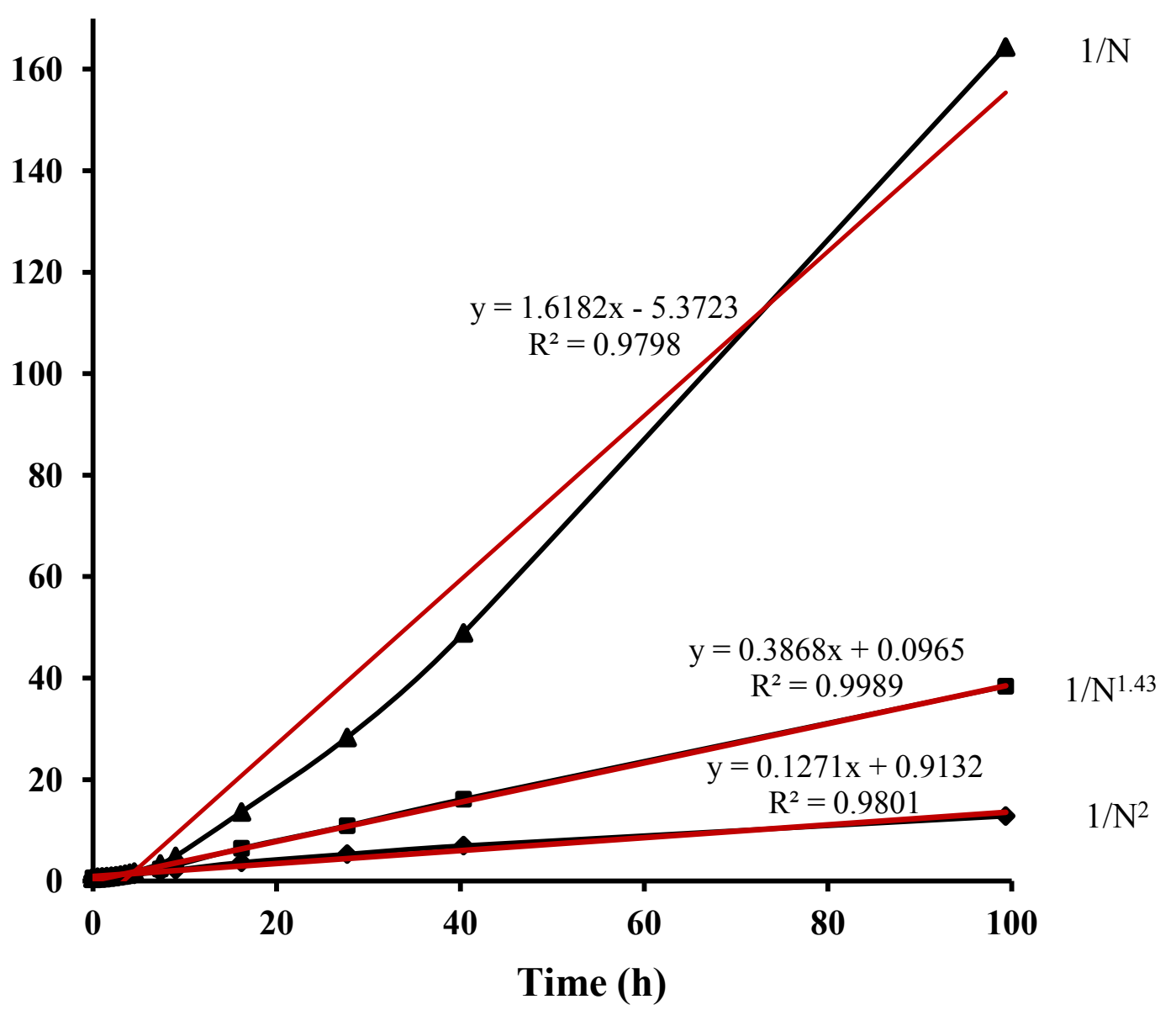

Figure 6.7 Reaction order fitting of the degradation of $\mathrm{Li}_{13} \mathrm{~N}_{4} \mathrm{Br}$ in air: $1 / \mathrm{N}-\mathrm{t}$, $1 / \mathrm{N}^{1.43}-\mathrm{t}$, and $1 / \mathrm{N}^{2}-\mathrm{t}$.

\subsection{Conclusion}

The chemical stability of $\mathrm{Li}_{13} \mathrm{~N}_{4} \mathrm{Br}$ in air has been investigated by XRD, TPD-MS, and UV-vis absorption as a function of time. A high reactivity of the lithium nitride bromide $\left(\mathrm{Li}_{13} \mathrm{~N}_{4} \mathrm{Br}\right)$ with oxygen and water in air is found with the rapid color change of the sample, from bright brick red to white. The aging process 
finally leads to the degradation of the lithium nitride bromide $\left(\mathrm{Li}_{13} \mathrm{~N}_{4} \mathrm{Br}\right)$ into lithium carbonate $\left(\mathrm{Li}_{2} \mathrm{CO}_{3}\right)$, lithium bromite $\left(\mathrm{LiBrO}_{2}\right)$ and the release of gaseous $\mathrm{NH}_{3}$. The reaction order $\mathrm{n}=2.43$ is the best fitting for the $\mathrm{Li}_{13} \mathrm{~N}_{4} \mathrm{Br}$ degradation in air reaction. $\mathrm{Li}_{13} \mathrm{~N}_{4} \mathrm{Br}$ energy gap was calculated to be $2.61 \mathrm{eV}$. 


\section{Chapter 7 Summary}

The decompositions of $\mathrm{LiNH}_{2}$ and $\mathrm{Li}_{2} \mathrm{NH}$ were evaluated. It was found that the decomposition of $\mathrm{LiNH}_{2}$ produced $\mathrm{Li}_{2} \mathrm{NH}$ and $\mathrm{NH}_{3}$ via two-steps: $\mathrm{LiNH}_{2}$ into a stable intermediate species $\left(\mathrm{Li}_{1.5} \mathrm{NH}_{1.5}\right)$ and then into $\mathrm{Li}_{2} \mathrm{NH}$.

The decomposition of $\mathrm{Li}_{2} \mathrm{NH}$ produced $\mathrm{Li}, \mathrm{N}_{2}$ and $\mathrm{H}_{2}$ via two steps: (1) $\mathrm{Li}_{2} \mathrm{NH}$ into $\mathrm{Li}_{4} \mathrm{NH}, \mathrm{N}_{2}$, and $\mathrm{H}_{2}$ and (2) $\mathrm{Li}_{4} \mathrm{NH}$ into $\mathrm{Li}, \mathrm{N}_{2}$, and $\mathrm{H}_{2}$. The first step is the seond-order reaction with activation energy of $533.6 \mathrm{~kJ} / \mathrm{mol}$, whereas the second step is the first-order reaction with activation energy of $754.2 \mathrm{~kJ} / \mathrm{mol}$. $\mathrm{Li}_{4} \mathrm{NH}$, which was generated in the decomposition of $\mathrm{Li}_{2} \mathrm{NH}$, formed a solid solution with $\mathrm{Li}_{2} \mathrm{NH}$. In the solid solution, $\mathrm{Li}_{4} \mathrm{NH}$ possesses a similar cubic structure as $\mathrm{Li}_{2} \mathrm{NH}$. The lattice parameter of cubic $\mathrm{Li}_{4} \mathrm{NH}$ is $0.5033 \mathrm{~nm}$.

Chloride ion $\left(\mathrm{Cl}^{-}\right)$had great effects on the decompositions of $\mathrm{LiNH}_{2}$ and $\mathrm{Li}_{2} \mathrm{NH}$. The introduction of $\mathrm{Cl}^{-}$resulted in the generation of a new peak at low temperature of about $250{ }^{\circ} \mathrm{C}$ besides the original peak at $330{ }^{\circ} \mathrm{C}$ in the decomposition of $\mathrm{LiNH}_{2}$ into $\mathrm{Li}_{2} \mathrm{NH}$ and $\mathrm{NH}_{3}$. Furthermore, $\mathrm{Cl}^{-}$showed an even greater effect on the decomposition of $\mathrm{Li}_{2} \mathrm{NH}$, namely, the two peaks in TPD profiles

merged into one and the peak temperature decrease from 645 to $530{ }^{\circ} \mathrm{C}$ with increasing molar ratio of $\mathrm{LiCl}$ to $\mathrm{LiNH}_{2}$.

The degradation of $\mathrm{Li}_{3} \mathrm{~N}$ in air was evaluated by XRD, FT-IR, and UV-vis absorption. $\mathrm{O}_{2}$ had no effect on $\mathrm{Li}_{3} \mathrm{~N}$ at room temperature, because the reaction between $\mathrm{Li}_{3} \mathrm{~N}$ and $\mathrm{O}_{2}$ requires a temperature of $230{ }^{\circ} \mathrm{C}$ or higher. However, $\mathrm{Li}_{3} \mathrm{~N}$ 
exhibited a high reactivity with $\mathrm{H}_{2} \mathrm{O}$ vapor in air at room temperature, leading to the conversion of $\mathrm{Li}_{3} \mathrm{~N}$ to $\mathrm{LiOH}$ and then to $\mathrm{Li}_{2} \mathrm{CO}_{3}$. Furthermore, it was found that degradation of $\beta-\mathrm{Li}_{3} \mathrm{~N}$ in air was much faster than $\alpha-\mathrm{Li}_{3} \mathrm{~N}$. This indicates that $\alpha-\mathrm{Li}_{3} \mathrm{~N}$ is more stable than $\beta-\mathrm{Li}_{3} \mathrm{~N}$ in air.

The chemical stability of $\mathrm{Li}_{13} \mathrm{~N}_{4} \mathrm{Br}$ in air has been investigated by XRD, TPD-MS, and UV-vis absorption as a function of time. A high reactivity of the lithium nitride bromide $\left(\mathrm{Li}_{13} \mathrm{~N}_{4} \mathrm{Br}\right)$ with air moisture is found with the rapid color change of the sample, from bright brick red to white. The aging process finally leads to the degradation of the lithium nitride bromide $\left(\mathrm{Li}_{13} \mathrm{~N}_{4} \mathrm{Br}\right)$ into lithium carbonate $\left(\mathrm{Li}_{2} \mathrm{CO}_{3}\right)$, lithium bromite $\left(\mathrm{LiBrO}_{2}\right)$ and the release of gaseous $\mathrm{NH}_{3}$. The reaction order $\mathrm{n}=2.43$ is the best fitting for the $\mathrm{Li}_{13} \mathrm{~N}_{4} \mathrm{Br}$ degradation in air reaction. $\mathrm{Li}_{13} \mathrm{~N}_{4} \mathrm{Br}$ energy gap was calculated to be $2.61 \mathrm{eV}$. 


\section{References}

1. DOE, Annual Energy Review 2011. U.S. Energy Information Administration: p. 144.

2. Schlapbach, L. and A. Zuttel, Hydrogen-storage materials for mobile applications. Nature, 2001. 414(6861): p. 353-358.

3. Fichtner, M., Nanotechnological aspects in materials for hydrogen storage. Advanced Engineering Materials, 2005. 7(6): p. 443-455.

4. Thomas, G., Overview of storage development DOE hydrogen program. Presented at the U.S. DOE hydrogen program 2000 annual review, San Ramon, CA.

5. Migliardini, F., O. Veneri, and P. Corbo, Hydrogen and proton exchange membrane fuel cells for clean road transportation. Journal of Industrial and Engineering Chemistry, 2011. 17(3): p. 633-641.

6. DOE, Targets for onboard hydrogen storage systems for light-duty vehicles. US department of energy, office of energy efficiency and renewable energy and the FreedomCAR and fuel partnership, 2009.

7. Zuttel, A., Hydrogen storage methods. Naturwissenschaften, 2004. 91(4): p. $157-172$.

8. Leung, W.B., N.H. March, and H. Motz, Primitive phase diagram for hydrogen. Physics Letters A, 1976. 56(6): p. 425-426. 
9. Yoon, J.H., Pressure-dependent hydrogen encapsulation in Na12-zeolite A. The Journal of Physical Chemistry, 1993. 97(22): p. 6066-6068.

10. Dillon, A.C. and M.J. Heben, Hydrogen storage using carbon adsorbents: past, present and future. Applied Physics a-Materials Science \& Processing, 2001. 72(2): p. 133-142.

11. Rosi, N.L., et al., Hydrogen storage in microporous metal-organic frameworks. Science, 2003. 300(5622): p. 1127-1129.

12. $\mathrm{Hu}, \mathrm{Y} . \mathrm{H}$. and L. Zhang, Hydrogen storage in metal-organic frameworks. Advanced Materials, 2010. 22(20): p. E117-E130.

13. Chae, H.K., et al., A route to high surface area, porosity and inclusion of large molecules in crystals. Nature, 2004. 427(6974): p. 523-527.

14. Furukawa, H., M.A. Miller, and O.M. Yaghi, Independent verification of the saturation hydrogen uptake in MOF-177 and establishment of a benchmark for hydrogen adsorption in metal-organic frameworks. Journal of Materials Chemistry, 2007. 17(30): p. 3197-3204.

15. Sinke, G.C., et al., Thermodynamic Properties of Aluminum Hydride. The Journal of Chemical Physics, 1967. 47(8): p. 2759-2761.

16. Siegel, D.J., C. Wolverton, and V. Ozoliņš, Thermodynamic guidelines for the prediction of hydrogen storage reactions and their application to destabilized hydride mixtures. Physical Review B, 2007. 76(13): p. 134102.

17. Libowitz, G.G., H.F. Hayes, and T.R.P. Gibb, The System Zirconium-Nickel and Hydrogen. The Journal of Physical Chemistry, 1958. 62(1): p. 76-79. 
18. Reilly, J.J. and R.H. Wiswall, Reaction of hydrogen with alloys of magnesium and nickel and the formation of $\mathrm{Mg} 2 \mathrm{NiH}$. Inorganic Chemistry, 1968. 7(11): p. 2254-2256.

19. Sandrock, G., A panoramic overview of hydrogen storage alloys from a gas reaction point of view. Journal of Alloys and Compounds, 1999. 293-295(0): p. 877-888.

20. Orimo, S.-i., et al., Complex Hydrides for Hydrogen Storage. Chemical Reviews, 2007. 107(10): p. 4111-4132.

21. Yang, J., et al., High capacity hydrogen storage materials: attributes for automotive applications and techniques for materials discovery. Chemical Society Reviews, 2010. 39(2): p. 656-675.

22. Zhou, L., Progress and problems in hydrogen storage methods. Renewable and Sustainable Energy Reviews, 2005. 9(4): p. 395-408.

23. Jain, I.P., P. Jain, and A. Jain, Novel hydrogen storage materials: A review of lightweight complex hydrides. Journal of Alloys and Compounds, 2010. 503(2): p. 303-339.

24. Thomas, G.J., et al., Microstructural characterization of catalyzed NaAlH4. Journal of Alloys and Compounds, 2002. 330-332(0): p. 702-707.

25. Mao, W.L. and H.K. Mao, Hydrogen storage in molecular compounds. Proceedings of the National Academy of Sciences of the United States of America, 2004. 101(3): p. 708-710. 
26. Mao, W.L., et al., Hydrogen clusters in clathrate hydrate. Science, 2002. 297(5590): p. 2247-2249.

27. Florusse, L.J., et al., Stable low-pressure hydrogen clusters stored in a binary clathrate hydrate. Science, 2004. 306(5695): p. 469-471.

28. Lee, H., et al., Tuning clathrate hydrates for hydrogen storage. Nature, 2005. 434(7034): p. 743-746.

29. Patchkovskii, S. and J.S. Tse, Thermodynamic stability of hydrogen clathrates. Proceedings of the National Academy of Sciences, 2003. 100(25): p. 1464514650.

30. Hu, Y.H. and E. Ruckenstein, Clathrate Hydrogen Hydrate-A Promising Material for Hydrogen Storage. Angewandte Chemie International Edition, 2006. 45(13): p. 2011-2013.

31. Dafert, F.W. and R. Miklauz, Über einige neue Verbindungen von Stickstoff und Wasserstoff mit Lithium. Monatshefte für Chemie und verwandte Teile anderer Wissenschaften, 1910. 31(9): p. 981-996.

32. Ruff, O. and H. Goerges, Über das Lithium-imid und einige Bemerkungen zu der Arbeit von Dafert und Miklauz: "Über einige neue Verbindungen von Stickstoff und Wasserstoff mit Lithium". Berichte der deutschen chemischen Gesellschaft, 1911. 44(1): p. 502-506.

33. Chen, P., et al., Interaction of hydrogen with metal nitrides and imides. Nature, 2002. 420(6913): p. 302-304. 
34. $\mathrm{Hu}, \mathrm{Y} . \mathrm{H}$. and E. Ruckenstein, Ultrafast reaction between $\mathrm{LiH}$ and $\mathrm{NH}_{3}$ during $H_{2}$ storage in $\mathrm{Li}_{3} \mathrm{~N}$. Journal of Physical Chemistry A, 2003. 107(46): p. 97379739.

35. Hu, Y.H. and E. Ruckenstein, Highly Effective $\mathrm{Li}_{2} \mathrm{O} / \mathrm{Li}_{3} \mathrm{~N}$ with Ultrafast Kinetics for $\mathrm{H}_{2}$ Storage. Industrial \& Engineering Chemistry Research, 2004. 43(10): p. 2464-2467.

36. Hu, Y.H., N.Y. Yu, and E. Ruckenstein, Effect of the heat pretreatment of $\mathrm{Li}_{3} \mathrm{~N}$ on Its $\mathrm{H}_{2}$ storage performance. Industrial and Engineering Chemistry Research, 2004. 43(15): p. 4174-4177.

37. Hu, Y.H., N.Y. Yu, and E. Ruckenstein, Hydrogen storage in $\operatorname{Li}_{3} N$ : Deactivation caused by a high dehydrogenation temperature. Industrial and Engineering Chemistry Research, 2005. 44(12): p. 4304-4309.

38. Hu, Y.H. and E. Ruckenstein, High reversible hydrogen capacity of $\mathrm{LiNH}_{2} / \mathrm{Li}_{3} \mathrm{~N}$ mixtures. Industrial and Engineering Chemistry Research, 2005. 44(5): p. 1510-1513.

39. Ichikawa, T., et al., Mechanism of novel reaction from $\mathrm{LiNH}_{2}$ and $\mathrm{LiH}$ to $\mathrm{Li}_{2} \mathrm{NH}$ and $\mathrm{H}_{2}$ as a promising hydrogen storage system. Journal of Physical Chemistry B, 2004. 108(23): p. 7887-7892.

40. Ichikawa, T., et al., Hydrogen storage properties in Ti catalyzed Li-N-H system. Journal of Alloys and Compounds, 2005. 404: p. 435-438.

41. Nakamori, Y., et al., Synthesis of $\mathrm{LiNH}_{2}$ films by vacuum evaporation. Journal of Alloys and Compounds, 2004. 377(1-2): p. L1-L3. 
42. Kojima, Y. and Y. Kawai, Hydrogen storage of metal nitride by a mechanochemical reaction. Chemical Communications, 2004(19): p. 22102211.

43. Markmaitree, T., R. Ren, and L.L. Shaw, Enhancement of lithium amide to lithium imide transition via mechanical activation. Journal of Physical Chemistry B, 2006. 110(41): p. 20710-20718.

44. Yang, J., A. Sudik, and C. Wolverton, Activation of hydrogen storage materials in the Li-Mg-N-H system: Effect on storage properties. Journal of Alloys and Compounds, 2007. 430(1-2): p. 334-338.

45. Dolotko, O., et al., Mechanochemical transformations in $\mathrm{Li}(\mathrm{Na}) \mathrm{AlH}_{4^{-}}$ Li(Na) $\mathrm{NH}_{2}$ systems. Acta Materialia, 2007. 55(9): p. 3121-3130.

46. Luo, W.F., $\left(\mathrm{LiNH}_{2}-\mathrm{MgH}_{2}\right)$ : a viable hydrogen storage system. Journal of Alloys and Compounds, 2004. 381(1-2): p. 284-287.

47. Ichikawa, T., et al., Lithium nitride for reversible hydrogen storage. Journal of Alloys and Compounds, 2004. 365(1-2): p. 271-276.

48. Nakamori, Y. and S. Orimo, Li-N based hydrogen storage materials. Materials Science and Engineering B-Solid State Materials for Advanced Technology, 2004. 108(1-2): p. 48-50.

49. Yao, J.H., et al., Desorption characteristics of mechanically and chemically modified $\mathrm{LiNH}_{2}$ and $\left(\mathrm{LiNH}_{2}+\mathrm{LiH}\right)$. Journal of Alloys and Compounds, 2007. 432(1-2): p. 277-282. 
50. Gregory, D.H., Lithium nitrides, imides and amides as lightweight, reversible hydrogen stores. Journal of Materials Chemistry, 2008. 18(20): p. 2321-2330.

51. Gregory, D.H., Lithium nitrides as sustainable energy materials. The Chemical Record, 2008. 8(4): p. 229-239.

52. Hu, Y.H. and E. Ruckenstein, Ultrafast Reaction between $\mathrm{Li}_{3} \mathrm{~N}$ and $\mathrm{LiNH}_{2}$ To Prepare the Effective Hydrogen Storage Material $\mathrm{Li}_{2} \mathrm{NH}$. Industrial \& Engineering Chemistry Research, 2006. 45(14): p. 4993-4998.

53. Kojima, Y. and Y. Kawai, IR characterizations of lithium imide and amide. Journal of Alloys and Compounds, 2005. 395(1-2): p. 236-239.

54. Moody, G.J. and J.D.R. Thomas, Alkali metal nitrides. Journal of Chemical Education, 1966. 43(4): p. 205.

55. Fischer, D. and M. Jansen, Synthesis and Structure of $\mathrm{Na}_{3} \mathrm{~N}$. Angewandte Chemie International Edition, 2002. 41(10): p. 1755-1756.

56. Fischer, D., et al., Zur Synthese und Struktur von $K_{3} N$. Zeitschrift für anorganische und allgemeine Chemie, 2004. 630(1): p. 156-160.

57. Brese, N.E. and M. Okeeffe, Crystal chemistry of inorganic nitrides. Structure and Bonding, 1992. 79: p. 307-378.

58. Zintl, E. and G. Brauer, Constitution of lithium nitride. Z. Elektrochem., 1935. 41: p. 102-107.

59. Rabenau, A. and H. Schulz, Re-evaluation of the lithium nitride structure. Journal of the Less Common Metals, 1976. 50(1): p. 155-159. 
60. Gregory, D.H., et al., Structure of lithium nitride and transition-metal-doped derivatives, $\operatorname{Li}_{3-x-y} M_{x} N(M=N i, C u)$ : a powder neutron diffraction study. Chemistry of Materials, 2002. 14(5): p. 2063-2070.

61. Lapp, T., S. Skaarup, and A. Hooper, Ionic conductivity of pure and doped $\mathrm{Li}_{3} \mathrm{~N}$. Solid State Ionics, 1983. 11(2): p. 97-103.

62. Brendecke, H. and E. Wagner, Electronic properties of superionic conductor $\mathrm{Li}_{3} N$. Journal of The Electrochemical Society, 1977. 124(8): p. C305-C305.

63. Wahl, J. and U. Holland, Local ionic motion in the superionic conductor $\mathrm{Li}_{3} N$. Solid State Communications, 1978. 27(3): p. 237-241.

64. Boukamp, B.A. and R.A. Huggins, Lithium ion conductivity in lithium nitride. Physics Letters A, 1976. 58(4): p. 231-233.

65. Alpen, U.V., A. Rabenau, and G.H. Talat, Ionic conductivity in $\mathrm{Li}_{3} \mathrm{~N}$ single crystals. Applied Physics Letters, 1977. 30(12): p. 621-623.

66. Schulz, H. and K.H. Thiemann, Defect structure of the ionic conductor lithium nitride ( $\left.\mathrm{Li}_{3} \mathrm{~N}\right)$. Acta Crystallographica Section A, 1979. 35(MAR): p. 309-314.

67. Mali, M., J. Roos, and D. Brinkmann, Nuclear-magnetic-resonance evidence for a new phase induced by pressure in the superionic conductor $\mathrm{Li}_{3} \mathrm{~N}$. Physical Review B, 1987. 36(7): p. 3888-3890.

68. Schon, J.C., M.A.C. Wevers, and M. Jansen, Prediction of high pressure phases in the systems $\mathrm{Li}_{3} \mathrm{~N}, \mathrm{Na} a_{3} \mathrm{~N}, \quad(\mathrm{Li}, \mathrm{Na})_{3} \mathrm{~N}, \mathrm{Li}_{2} \mathrm{~S}$ and $\mathrm{Na} \mathrm{a}_{2} \mathrm{~S}$. Journal of Materials Chemistry, 2001. 11(1): p. 69-77. 
69. Beister, H.J., et al., Phase transformations of lithium nitride under pressure. Angewandte Chemie International Edition, 1988. 27(8): p. 1101-1103.

70. Li, W., et al., $\mathrm{Li}^{+}$ion conductivity and diffusion mechanism in $\alpha-L i_{3} N$ and $\beta$ $\mathrm{Li}_{3} N$. Energy \& Environmental Science, 2010. 3(10): p. 1524-1530.

71. Huo, Y. and Y.H. Hu, UV-visible absorption spectrum determination of optical energy gaps of $\alpha$ and $\beta$ lithium nitrides. Journal of Physics and Chemistry of Solids, 2012. 73(8): p. 999-1002.

72. Ho, A.C., et al., Experimental and theoretical study of $L i_{3} N$ at high pressure. Physical Review B, 1999. 59(9): p. 6083-6086.

73. Lazicki, A., et al., New cubic phase of $L i_{3} N$ : stability of the $N^{3-}$ ion to $200 \mathrm{GPa}$. Physical Review Letters, 2005. 95(16): p. 165503.

74. Brendecke, H. and W. Bludau, Optical absorption of lithium nitride. Journal of Applied Physics, 1979. 50(7): p. 4743-4746.

75. Brendecke, H. and W. Bludau, Photoluminescence properties of lithium nitride. Physical Review B, 1980. 21(2): p. 805-815.

76. Kerker, G., Electronic structure of $L i_{3} N$. Physical Review B, 1981. 23(12): p. 6312-6318.

77. Dovesi, R., et al., Hartree-Fock study of crystalline lithium nitride. Physical Review B, 1984. 30(2): p. 972-979.

78. Lazicki, A., et al., Pressure-induced loss of electronic interlayer state and metallization in the ionic solid $\mathrm{Li}_{3} N$ : Experiment and theory. Physical Review B, 2008. 78(15): p. 155133. 
79. Fister, T.T., et al., The local electronic structure of $\alpha-L i_{3} N$. Journal of Chemical Physics, 2008. 129(4): p. 044702.

80. Wu, S.N., et al., Electronic structure and vacancy formation of $\mathrm{Li}_{3} \mathrm{~N}$. Applied Physics Letters, 2009. 94(17): p. 172104.

81. Cui, S., et al., Structural transition of $\mathrm{Li}_{3} N$ under high pressure: A firstprinciples study. Solid State Communications, 2009. 149(15-16): p. 612-615.

82. Li, W., J.F. Chen, and T. Wang, Electronic and elastic properties of $\mathrm{Li}_{3} \mathrm{~N}$ under different pressure. Physica B, 2010. 405(1): p. 400-403.

83. Hamann, D.R., Semiconductor charge densities with hard-core and soft-core pseudopotentials. Physical Review Letters, 1979. 42(10): p. 662-665.

84. Sattlegger, H. and H. Hahn, Über Versuche zur Umsetzung von $\mathrm{Li}_{3} \mathrm{~N}$ mit Lithiumhalogeniden. Naturwissenschaften, 1964. 51(22): p. 534-535.

85. Hartwig, P., W. Weppner, and W. Wichelhaus, Fast ionic lithium conduction in solid lithium nitride chloride. Materials Research Bulletin, 1979. 14(4): p. 493-498.

86. Hartwig, P., et al., Ionic transport in the lithium nitride bromides, $\mathrm{Li}_{6} \mathrm{NBr}_{3}$ and $L i_{13} N_{4} B r$. Solid State Communications, 1979. 30(10): p. 601-603.

87. Hartwig, P., et al., Lithium Nitride Halides—New Solid Electrolytes with High $\mathrm{Li}^{+}$Ion Conductivity. Angewandte Chemie International Edition in English, 1980. 19(1): p. 74-75. 
88. Hartwig, P., A. Rabenau, and W. Weppner, Phase equilibria and thermodynamic properties of the $\mathrm{Li}-\mathrm{N}-\mathrm{Cl}, \mathrm{Li}-\mathrm{N}-\mathrm{Br}$ and $\mathrm{Li}-\mathrm{N}-\mathrm{I}$ systems. Journal of the Less Common Metals, 1981. 80(1): p. 81-90.

89. Weppner, W., P. Hartwig, and A. Rabenau, Consideration of lithium nitride halides as solid electrolytes in practical galvanic cell applications. Journal of Power Sources, 1981. 6(3): p. 251-259.

90. Kitahama, K., Y. Furukawa, and S. Kawai, X-ray and pulsed NMR-studies of lithium nitride chlorides in anti-fluorite type structures. Solid State Communications, 1980. 36(8): p. 703-705.

91. Obayashi, H., A. Gotoh, and R. Nagai, Composition dependence of lithium ionic conductivity in lithium nitride-lithium iodide system. Materials Research Bulletin, 1981. 16(5): p. 581-585.

92. Kitahama, K., et al., Synthesis and NMR study of solid electrolytes in the system $\mathrm{Li}_{3} \mathrm{~N}-\mathrm{LiCl}$. Solid State Ionics, 1981. 3-4(AUG): p. 335-339.

93. Marx, R., Preparation and crystal-structure of lithium trinitride bromide $L_{10} N_{3} B r$. Zeitschrift Fur Naturforschung Section B-a Journal of Chemical Sciences, 1995. 50(7): p. 1061-1066.

94. Marx, R. and H.M. Mayer, Preparation and crystal-structure of lithium nitride dibromide, $\mathrm{Li}_{5} \mathrm{NBr}_{2}$. Zeitschrift Fur Naturforschung Section B-a Journal of Chemical Sciences, 1995. 50(9): p. 1353-1358. 
95. Marx, R. and H.M. Mayer, Preparation and lithium sublattice of lithium nitride trihalides, $\mathrm{Li}_{6} \mathrm{NHal}_{3}(\mathrm{Hal}=\mathrm{Br}, \mathrm{I})$. Zeitschrift Fur Naturforschung Section B-a Journal of Chemical Sciences, 1996. 51(4): p. 525-530.

96. Marx, R., Preparation and crystal structure of lithium nitride chloride $\mathrm{Li}_{4} \mathrm{NCl}$. Journal of Solid State Chemistry, 1997. 128(2): p. 241-246.

97. Marx, R., Time-of-flight neutron diffraction study on the $\mathrm{Li}_{2} \mathrm{O}$ type phases of $\mathrm{Li}_{6} \mathrm{NBr}_{3}$. Journal of Alloys and Compounds, 1997. 256(1-2): p. 196-206.

98. Marx, R. and R.M. Ibberson, Time-of-flight neutron diffraction study on the cryolite type phases of $\mathrm{Li}_{6} \mathrm{NBr}_{3}$. Journal of Alloys and Compounds, 1997. 261(1-2): p. 123-131.

99. Marx, R. and H.M. Mayer, Preparation and crystal structure of ordered and disordered lithium nitride dichloride, $\mathrm{Li}_{5} \mathrm{NCl}_{2}$. Journal of Solid State Chemistry, 1997. 130(1): p. 90-96.

100. Marx, R., Time-of-flight neutron diffraction study on lithium dinitride iodide, $\mathrm{Li}_{7} \mathrm{~N}_{2} I$. European Journal of Solid State and Inorganic Chemistry, 1998. 35(3): p. 197-209.

101. Jia, Y. and J. Yang, Study of the lithium solid electrolytes based on lithium nitride chloride $\left(\mathrm{Li}_{9} \mathrm{~N}_{2} \mathrm{Cl}_{3}\right)$. Solid State Ionics, 1997. 96(1-2): p. 113-117.

102. Bräunling, D., et al., Synthesis, Crystal Structure and Lithium Motion of $\mathrm{Li}_{8} \mathrm{SeN}_{2}$ and $\mathrm{Li}_{8} \mathrm{TeN}_{2}$ Zeitschrift für anorganische und allgemeine Chemie, 2010. 636(6): p. 936-946. 
103. Rabenau, A., Lithium nitride and related materials case study of the use of modern solid state research techniques. Solid State Ionics, 1982. 6(4): p. 277293.

104. David, W.I.F., et al., A mechanism for non-stoichiometry in the lithium amide/lithium imide hydrogen storage reaction. Journal of the American Chemical Society, 2007. 129(6): p. 1594-1601.

105. Crivello, J.C., et al., Density functional study of $\mathrm{Li}_{4} \mathrm{NH}$ and $\mathrm{Li}_{1.5} \mathrm{NH}_{1.5}$ as intermediary compounds during hydrogenation of $L_{3} N$. Physical Review B, 2010. 81(10): p. 104113.

106. Juza, R. and K. Opp, Metallamide und Metallnitride, 25. Mitteilung. Zur Kenntnis des Lithiumimides. Zeitschrift für anorganische und allgemeine Chemie, 1951. 266(6): p. 325-330.

107. Pinkerton, F.E., Decomposition kinetics of lithium amide for hydrogen storage materials. Journal of Alloys and Compounds, 2005. 400(1-2): p. 76-82.

108. Alapati, S.V., J.K. Johnson, and D.S. Sholl, Identification of destabilized metal hydrides for hydrogen storage using first principles calculations. Journal of Physical Chemistry B, 2006. 110(17): p. 8769-8776.

109. Weidner, E., et al., Observation of novel phases during deuteration of lithium nitride from in situ neutron diffraction. Chemical Physics Letters, 2007. 444(13): p. 76-79. 
110. Ohoyama, K., et al., Revised crystal structure model of $\mathrm{Li}_{2} \mathrm{NH}$ by neutron powder diffraction. Journal of the Physical Society of Japan, 2005. 74(1): p. $483-487$.

111. Noritake, T., et al., Crystal structure and charge density analysis of $\mathrm{Li}_{2} \mathrm{NH}$ by synchrotron X-ray diffraction. Journal of Alloys and Compounds, 2005. 393(12): p. 264-268.

112. Balogh, M.P., et al., Crystal structures and phase transformation of deuterated lithium imide, $L i_{2} N D$. Journal of Alloys and Compounds, 2006. 420(1-2): p. 326-336.

113. Zhang, C.J., M. Dyer, and A. Alavi, Quantum delocalization of hydrogen in the $\mathrm{Li}_{2} \mathrm{NH}$ crystal. Journal of Physical Chemistry B, 2005. 109(47): p. 2208922091.

114. Mueller, T. and G. Ceder, Effective interactions between the $\mathrm{N}-\mathrm{H}$ bond orientations in lithium imide and a proposed ground-state structure. Physical Review B, 2006. 74(13): p. 134104.

115. Magyari-Köpe, B., V. Ozoliņ̌s, and C. Wolverton, Theoretical prediction of low-energy crystal structures and hydrogen storage energetics in $\mathrm{Li}_{2} \mathrm{NH}$. Physical Review B, 2006. 73(22): p. 220101.

116. Niewa, R. and D.A. Zherebtsov, Redetermination of the crystal structure of tetralithium mononitride monohydride, $\mathrm{Li}_{4} \mathrm{NH}$. Zeitschrift Fur KristallographieNew Crystal Structures, 2002. 217(3): p. 317-318. 
117. Marx, R., Preparation and crystal structure of lithium nitride hydride, $\mathrm{Li}_{4} \mathrm{NH}$, $\mathrm{Li}_{4} \mathrm{ND}$. Zeitschrift Fur Anorganische Und Allgemeine Chemie, 1997. 623(12): p. $1912-1916$.

118. Hu, Y.H., A method for calculating desorption kinetic parameters. Petrochemical Technology (China), 1986. 15(3): p. 167-170.

119. Chakrabarti, P., Anion-binding sites in protein structures. Journal of Molecular Biology, 1993. 234(2): p. 463-482.

120. Scheele, J., P. Timmerman, and D.N. Reinhoudt, A significant effect of anion binding ureas on the product ratio in the palladium(II)-catalyzed hydrocarbonylation of alkenes. Chemical Communications, 1998(23): p. 26132614.

121. Glidewell, C., The nitrate nitrite controversy. Chemistry in Britain, 1990. 26(2): p. $137-140$.

122. Holloway, J.M., et al., Contribution of bedrock nitrogen to high nitrate concentrations in stream water. Nature, 1998. 395(6704): p. 785-788.

123. Sun, M. and R. Prins, A kinetic investigation of the effects of fluorine and nickel on the HDN of toluidine on fully sulfided tungsten sulfide catalysts. Journal of Catalysis, 2001. 203(1): p. 192-200.

124. Schwartz, V., M.Y. Sun, and R. Prins, An EXAFS study of the influence of fluorine on the structure of sulfided $\mathrm{W} / \mathrm{Al}_{2} \mathrm{O}_{3}$ and $\mathrm{NiW} / \mathrm{Al}_{2} \mathrm{O}_{3}$ catalysts. Journal of Physical Chemistry B, 2002. 106(10): p. 2597-2605. 
125. Wang, P., X.D. Kang, and H.M. Cheng, Improved hydrogen storage of TiF $3_{3^{-}}$ doped $\mathrm{NaAlH}_{4}$. Chemphyschem, 2005. 6(12): p. 2488-2491.

126. Yin, L.-C., et al., Functional anion concept: effect of fluorine anion on hydrogen storage of sodium alanate. Physical Chemistry Chemical Physics, 2007. 9(12): p. 1499-1502.

127. Yin, L., et al., Thermodynamically tuning $\mathrm{LiBH}_{4}$ by fluorine anion doping for hydrogen storage: A density functional study. Chemical Physics Letters, 2008. 450(4-6): p. 318-321.

128. Ma, L.P., et al., Superior catalytic effect of $\mathrm{TiF}_{3}$ over $\mathrm{TiCl}_{3}$ in improving the hydrogen sorption kinetics of $\mathrm{MgH}_{2}$ : Catalytic role of fluorine anion. Acta Materialia, 2009. 57(7): p. 2250-2258.

129. Pinkerton, F.E., et al., Hydrogen desorption exceeding ten weight percent from the new quaternary hydride $\mathrm{Li}_{3} B \mathrm{~N}_{2} \mathrm{H}_{8}$. Journal of Physical Chemistry B, 2005. 109(1): p. 6-8.

130. Aoki, M., et al., Destabilization of $\mathrm{LiBH}_{4}$ by mixing with $\mathrm{LiNH}_{2}$. Applied Physics a-Materials Science \& Processing, 2005. 80(7): p. 1409-1412.

131. Chater, P.A., et al., Synthesis and crystal structure of $\mathrm{Li}_{4} \mathrm{BH}_{4}\left(\mathrm{NH}_{2}\right)_{3}$. Chemical Communications, 2006(23): p. 2439-2441.

132. Chater, P.A., et al., Synthesis and characterization of amide-borohydrides: New complex light hydrides for potential hydrogen storage. Journal of Alloys and Compounds, 2007. 446: p. 350-354. 
133. Bevers, E.R.T., et al., Thermodynamic properties of lithium chloride ammonia complexes for application in a high-lift high temperature chemical heat pump. Journal of Thermal Analysis and Calorimetry, 2006. 86(3): p. 825-832.

134. Johnson, C.E., S.E. Wood, and C.E. Crouthamel, Studies of Lithium Hydride Systems. I. Solid-Liquid Equilibrium in the Lithium Chloride-Lithium Hydride System. Inorganic Chemistry, 1964. 3(11): p. 1487-1491.

135. Hu, Y.H. and Y. Huo, Fast and exothermic reaction of $\mathrm{CO}_{2}$ and $\mathrm{Li}_{3} \mathrm{~N}$ into $\mathrm{C}-\mathrm{N}$ containing solid Materials. Journal of Physical Chemistry A, 2011. 115(42): p. 11678-11681.

136. Trudeau, M.L., Advanced materials for energy storage. Mrs Bulletin, 1999. 24(11): p. 23-24.

137. Abay, B., H.S. Guder, and Y.K. Yogurtcu, Urbach-Martienssen's tails in layered semiconductor GaSe. Solid State Communications, 1999. 112(9): p. 489-494.

138. Chandrasekhar, H.R., et al., Phonon spectra and lattice dynamics of lithium nitride. Solid State Communications, 1977. 22(11): p. 681-684.

139. Chandrasekhar, H.R., et al., Infrared and raman-spectra and lattice-dynamics of superionic conductor $\mathrm{Li}_{3} N$. Physical Review B, 1978. 17(2): p. 884-893.

140. Brooker, M.H. and J.B. Bates, Raman and infrared spectral studies of anhydrous $\mathrm{Li}_{2} \mathrm{CO}_{3}$ and $\mathrm{Na}_{2} \mathrm{CO}_{3}$. Journal of Chemical Physics, 1971. 54(11): p. 4788-4796. 
141. Pasierb, P., et al., Structural properties of $\mathrm{Li}_{2} \mathrm{CO}_{3}-\mathrm{BaCO}_{3}$ system derived from IR and Raman spectroscopy. Journal of Molecular Structure, 2001. 596(1-3): $\mathrm{p}$. $151-156$.

142. Jones, L.H., The infrared spectra and structure of $\mathrm{LiOH}, \mathrm{LiOHH}_{2} \mathrm{O}$ and the deuterium species. Remark on fundamental frequency of $\mathrm{OH}$. Journal of Chemical Physics, 1954. 22(2): p. 217-219.

143. Kamaya, N., et al., A lithium superionic conductor. Nat Mater, 2011. 10(9): p. $682-686$.

144. Yamane, H., S. Kikkawa, and M. Koizumi, Lithium aluminum nitride, $\mathrm{Li}_{3} \mathrm{AlN}_{2}$ as a lithium solid electrolyte. Solid State Ionics, 1985. 15(1): p. 51-54.

145. Panabière, E., et al., Chemical stability of layered lithium cobalt nitrides in air. Corrosion Science, 2012. 58(0): p. 237-241.

146. Cabana, J., et al., Oxynitrides as electrode materials for lithium-ion batteries Characterization and performance of $\mathrm{Li}_{7.9} \mathrm{MnN}_{3.2} \mathrm{O}_{1.6}$. Journal of The Electrochemical Society, 2005. 152(11): p. A2246-A2255.

147. Sotelo-Lerma, M., R.A. Zingaro, and S.J. Castillo, Preparation of CdTe coatings using the chemical deposition method. Journal of Organometallic Chemistry, 2001. 623(1-2): p. 81-86.

148. Riveros, G., et al., Electrodeposition and characterization of $\operatorname{ZnX}(X=S e, T e)$ semiconductor thin films. Boletin De La Sociedad Chilena De Quimica, 2002. 47(4): p. 411-429. 
149. Shen, W.Z., A Novel Approach for the Evaluation of Band Gap Energy in Semiconductors. International Journal of Infrared and Millimeter Waves, 2002. 23(1): p. 61-69. 


\section{Appendix}

\section{Figure 1.1, reference [1]}

Copyrights and Reuse

Public domain and use of EIA content

U.S. Government publications are in the public domain and are not subject to copyright protection. You may use and/or distribute any of our data, files, databases, reports, graphs, charts, and other information products that are on our website or that you receive through our email distribution service. However, if you use or reproduce any of our information products, you should use an acknowledgment, which includes the publication date.

http://www.eia.gov/about/copyrights_reuse.cfm

\section{Table 1.1, reference [4]; Table 1.2, reference [6]}

Copyright

Materials on the EERE Web site are in the public domain. EERE requests that it be acknowledged as the source in any subsequent use of its information.

http://www1.eere.energy.gov/webpolicies/\#copyright 
Figure 1.2, reference [7]; Figure 1.3, reference [7]

This is a License Agreement between Junqing Zhang ("You") and Springer ("Springer") provided by Copyright Clearance Center ("CCC"). The license consists of your order details, the terms and conditions provided by Springer, and the payment terms and conditions.

$\begin{array}{ll}\text { License Number } & 3152830859885 \\ \text { License date } & \text { May 19, } 2013 \\ \text { Licensed content publisher } & \text { Springer } \\ \text { Licensed content publication } & \text { Naturwissenschaften } \\ \text { Licensed content title } & \text { Hydrogen storage methods } \\ \text { Licensed content author } & \text { Andreas Züttel } \\ \text { Licensed content date } & \text { Jan 1, 2004 } \\ \text { Volume number } & 91 \\ \text { Issue number } & 4 \\ \text { Type of Use } & \text { Thesis/Dissertation } \\ \text { Portion } & \text { Figures } \\ \text { Author of this Springer article } & \text { No } \\ \text { Order reference number } & \\ \text { Title of your thesis / } & \text { PROPERTIES AND STRUCTURES OF Li-N } \\ \text { dissertation } & \text { BASED HYDROGEN STORAGE MATERIALS } \\ \text { Expected completion date } & \text { Jun 2013 } \\ \text { Estimated size(pages) } & 1 \\ \text { Total } & 0.00 \text { USD }\end{array}$


Figure 1.4, reference [53]

This is a License Agreement between Junqing Zhang ("You") and Elsevier ("Elsevier") provided by Copyright Clearance Center ("CCC"). The license consists of your order details, the terms and conditions provided by Elsevier, and the payment terms and conditions.

\begin{tabular}{ll} 
Supplier & Elsevier Limited \\
& The Boulevard,Langford Lane \\
& Kidlington,Oxford,OX5 1GB,UK \\
Registered Company Number & 1982084 \\
Customer name & Junqing Zhang \\
Customer address & $1806 \mathrm{~B}$, Woodmar Dr. \\
& Houghton, MI 49931 \\
License number & 3152841507404 \\
License date & May 19, 2013 \\
Licensed content publisher & Elsevier \\
Licensed content publication & Journal of Alloys and Compounds \\
Licensed content title & IR characterizations of lithium imide and \\
Licensed content author & amide \\
Licensed content date & Yoshitsugu Kojima, Yasuaki Kawai \\
Licensed content volume & 31 May 2005 \\
number & 395 \\
Licensed content issue number & $1-2$ \\
Number of pages & 4 \\
Intart Page & 236 \\
\hline End Page & 239 \\
\hline
\end{tabular}


Portion

Number of

figures/tables/illustrations

Format

Are you the author of this

Elsevier article?

Will you be translating?

Order reference number

Title of your thesis/dissertation

Expected completion date

Estimated size (number of

pages)

Elsevier VAT number

Permissions price

VAT/Local Sales Tax

Total figures/tables/illustrations

1

both print and electronic

No

No

PROPERTIES AND STRUCTURES OF

Li-N BASED HYDROGEN STORAGE

MATERIALS

Jun 2013

1

GB 494627212

0.00 USD

$0.0 \mathrm{USD} / 0.0 \mathrm{GBP}$

0.00 USD

Figure 4.1, reference [40]

This is a License Agreement between Junqing Zhang ("You") and Elsevier ("Elsevier") provided by Copyright Clearance Center ("CCC"). The license consists of your order details, the terms and conditions provided by Elsevier, and the payment terms and conditions. 
Supplier

Registered Company Number

Customer name

Customer address

License number

License date

Licensed content publisher

Licensed content publication

Licensed content title

Licensed content author

Licensed content date

Licensed content volume number

Licensed content issue number

Number of pages

Start Page

End Page

Type of Use

Intended publisher of new work

Portion

Number of figures/tables/illustrations

Format

Are you the author of this Elsevier

article?

Will you be translating?
Elsevier Limited

The Boulevard, Langford Lane

Kidlington,Oxford,OX5 1GB,UK

1982084

Junqing Zhang

1806B, Woodmar Dr.

Houghton, MI 49931

3153080090347

May 20, 2013

Elsevier

Journal of Alloys and Compounds

Hydrogen storage properties in $\mathrm{Ti}$

catalyzed $\mathrm{Li}-\mathrm{N}-\mathrm{H}$ system

T. Ichikawa,N. Hanada,S. Isobe,H.Y.

Leng,H. Fujii

8 December 2005

404-406

4

435

438

reuse in a thesis/dissertation

other

figures/tables/illustrations

\section{1}

both print and electronic

No

No 
Order reference number

Title of your thesis/dissertation

PROPERTIES AND STRUCTURES OF

Li-N BASED HYDROGEN STORAGE

MATERIALS

Expected completion date

Jun 2013

Estimated size (number of pages)

1

Elsevier VAT number

GB 494627212

Permissions price

0.00 USD

VAT/Local Sales Tax

$0.0 \mathrm{USD} / 0.0 \mathrm{GBP}$

Total

0.00 USD

Chapter 2 and Chapter 4

Reprinted (adapted) with permission from (Zhang, J.; Hu, Y. H., Decomposition of Lithium Amide and Lithium Imide with and without Anion Promoter. Ind. Eng. Chem. Res. 2011, 50 (13), 8058-8064). Copyright (2011) American Chemical Society. 
Copyright

Clearance

Center

ACS Publications Title:

High quality. High impact.
Decomposition of Lithium Amide and Lithium Imide with and without Anion Promoter

Author: Junging Zhang and Yun Hang $\mathrm{Hu}$

Publication: Industrial \& Engineering Chemistry Research

Publisher: American Chemical Society

Date: Jul 1, 2011

Copyright (s) 2011, American Chemical Society
Logged in as:

Junqing Zhang

Account \# :

3000649899

LOGOUT

\section{PERMISSION/LICENSE IS GRANTED FOR YOUR ORDER AT NO CHARGE}

This type of permission/license, instead of the standard Terms \& Conditions, is sent to you because no fee is being charged for your order. Please note the following:

- Permission is granted for your request in both print and electronic formats, and translations.

- If figures and/or tables were requested, they may be adapted or used in part.

- Please print this page for your records and send a copy of it to your publisher/graduate school.

- Appropriate credit for the requested material should be given as follows: "Reprinted (adapted) with permission from (COMPLETE REFERENCE CITATION). Copyright (YEAR) American Chemical Society." Insert appropriate information in place of the capitalized words.

- One-time permission is granted only for the use specified in your request. No additional uses are granted (such as derivative works or other editions). For any other uses, please submit a new request.

\section{BACK}

\section{CLOSE WINDOW}

Copyright (9) 2013 Copyright Clearance Center, Inc, All Rights Reserved. Privacy statement. comments? We would like to hear from you. E-mail us at customercarealcopuriqht, com

\section{Chapter 3}

\section{To: Junqing Zhang [junqingz@mtu.edu]}

Cc: Emre A. Veziroglu [emrev1@,cox.net]

Subject: Copyright Permission 
Dear Junqing:

Thank you very much for your email of 20 May 2013. In accordance with your request, we are happy to give you permission to use the following article both electronically and in print in your $\mathrm{PhD}$ thesis:

"Zhang, Junqing, and Yun Hang Hu. Intermediate Species and Kinetics of Lithium Imide Decomposition. International Journal of Hydrogen Energy 2012, 37 (13), 10467-10472

Wishing you all the best in your endeavors, I remain

Sincerely yours,

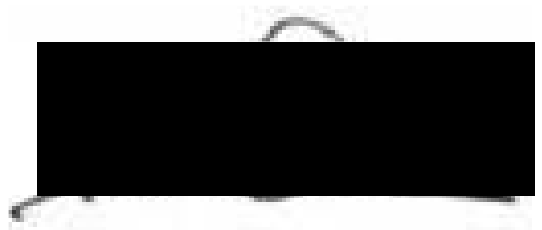

T. Nejat Veziroglu

Founding Editor-in-Chief

International Journal of Hydrogen Energy (IJHE)

5794 SW 40 St. \#303

Miami, FI 33155, USA

Tel: $\underline{1-305-456-9353}$ 
Fax: 1-305-675-3295

Email: veziroglu@iahe.org 